\title{
Consensus Report on Diagnosis, Treatment and Prevention of Infective
} Endocarditis by Turkish Society of Cardiovascular Surgery (TSCVS), Turkish Society of Clinical Microbiology and Infectious Diseases (KLIMIK), Turkish Society of Cardiology (TSC), Turkish Society of Nuclear Medicine (TSNM), Turkish Society of Radiology (TSR), Turkish Dental Association (TDA) and Federation of Turkish Pathology Societies (TURKPATH) Cardiovascular System Study Group

\author{
Türk Kalp Damar Cerrahisi Derneği (TKDCD), Türk Klinik Mikrobiyoloji ve Infeksiyon Hastalıkları Derneği \\ (KLIMiK), Türk Kardiyoloji Derneği (TKD), Türk Nükleer Tıp Derneği (TNTD), Türk Radyoloji Derneği (TRD), \\ Türk Diş Hekimleri Birliği (TDB) ve Türk Patoloji Dernekleri Federasyonu (TURKPATH) Kalp Damar Sistemi \\ Çalışma Grubu'nun Infektif Endokarditin Tanısı, Tedavisi ve Önlenmesine ilişkin Ulusal Uzlaşı Raporu
}

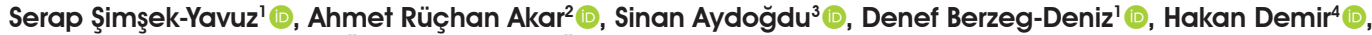

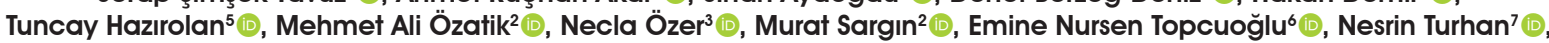
Mehmet Birhan Yılmaz ${ }^{3}$ (D), Infective Endocarditis and Other Cardiovascular Infections Study Group'

\author{
'Turkish Society of Clinical Microbiology and Infectious Diseases, Istanbul, Turkey \\ ${ }^{2}$ Turkish Society of Cardiovascular Surgery, Istanbul, Turkey \\ ${ }^{3}$ Turkish Society of Cardiology, Istanbul, Turkey \\ ${ }^{4}$ Turkish Society of Nuclear Medicine, Ankara, Turkey \\ ${ }^{5}$ Turkish Society of Radiology, Ankara, Turkey \\ 'Turkish Dental Association, Ankara, Turkey \\ ${ }^{7}$ Federation of Turkish Pathology Societies, Cardiovascular System Study Group, Ankara, Turkey
}

\section{ABSTRACT}

Infective endocarditis (IE) is rare, but associated with significant morbidity and mortality rates. Estimates of the incidence of IE in Turkey are compromised by the absence of population-based prospective studies. Due to the frequent presence of predisposing cardiac conditions and higher rates of nosocomial bacteremia in highrisk groups, the incidence of IE is expected to be higher in Turkey. Additionally, while IE generally affects older people in developed countries, it still affects young people in Turkey. In order to reduce the mortality and morbidity, it is critical to diagnose the IE to determine the causative agent and to start treatment rapidly. However, most of the patients cannot be diagnosed in their first visits, about half of them can be diagnosed after three months, and the disease often goes unnoticed. In patients diagnosed with IE, the rate of identification of causative organisms is significantly lower in Turkey than in developed countries. Furthermore, most of the centers do not perform some essential microbiological diagnostic tests as a routine practice. Some antimicrobials that are recommended as the first-line of treatment for IE, particularly antistaphylococcal penicillins, are not available in Turkey. These problems necessitate reviewing the epidemiological, laboratory, and clinical characteristics of IE in our country, as well as the current information about its diagnosis, treatment, and prevention together with local data. Physicians can follow patients with IE in many specialties. Diagnosis an treatment processes of IE should be standardized at every stage so that management of IE, a setting in which many physicians are involved, can always be in line with current recommendations. Study Group for Infective Endocarditis and Other Cardiovascular Infections of the Turkish Society of Clinical Microbiology and Infectious Diseases has called for collaboration of the relevant specialist organizations to establish a consensus report on the diagnosis, treatment, and prevention of IE in the light of current information and local data in Turkey.

Keywords: Diagnosis, endocarditis, prevention, treatment.
$\ddot{O} Z$

İnfektif endokardit (İE) nadir görülmesine karșn, önemli morbidite ve mortaliteye neden olan bir hastalıktır. Türkiye'de İE insidensi konusunda yapılmış toplum temelli prospektif çalışmalar bulunmadığı için hastalığın insidensi tam olarak bilinmemektedir. Ancak gerek İE yatkınlı̆̆ını artıran durumların, gerekse riskli hastalarda İE ile sonuçlanabilen nozokomiyal bakteriyemi oranlarının daha fazla olması nedeniyle, ülkemizdeki İE insidansının daha yüksek olması beklenir. Ek olarak gelişmiş ülkelerde genellikle yaşlı insanları etkileyen IE, ülkemizde halen genç insanları etkileyebilmektedir. Bu hastalı̆̆ın mortalite ve morbiditesinin azaltılması için, hızlıca tanınması ve etkeninin belirlenerek, etkene yönelik tedavisinin yapılması kritik öneme sahiptir. Ancak hastaların çoğuna ilk başvurularında tanı konulamamakta, yaklaşık yarıında tanı üç aydan sonra konulabilmekte ve hastalık sıklıkla gözden kaçmaktadır. İnfektif endokardit tanısı konulmuş hastalarda, bu infeksiyona neden olan mikroorganizmaların belirlenme oranı gelismis ülkelere göre Türkiye'de çok daha düsüktür. İnfektif endokarditli hastaların tanısının konulmasında kullanılabilecek bazı önemli mikrobiyolojik testler bu hastaları izleyen merkezlerin çoğunda yapılamamaktadır. Tedavide ilk seçenek olarak önerilen, bașta antistafilokoksik penisilinler olmak üzere önemli bazı antimikrobik ajanlar ülkemizde piyasada yoktur. Bu sorunlar, ülkemizde hem IE'nnin epidemiyolojik, laboratuvar ve klinik özelliklerini, hem de tanısı, tedavisi ve önlenmesiyle ilgili güncel bilgileri, yerel verileri de içerecek şekilde gözden geçirmeyi zorunlu kılmaktadır. İnfektif endokarditli hastalar birçok uzmanlık dalından hekim tarafından izlenebilir. Birçok daldan hekimin rol aldığı İE’li hastaların yönetiminin daima güncel önerilere uygun olarak yapılabilmesi için, İ'nin tanı ve tedavi süreçlerinin her aşamada standardize edilmesi gerekir. Bu bakış açısıyla, Türk Klinik Mikrobiyoloji ve İnfeksiyon Hastalıkları Derneği İnfektif Endokardit ve Diğger Kardiyovasküler İnfeksiyonlar Çalışma Grubu, ülkemizde güncel bilgilerin ve yerel verilerin ışı̆̆ında İE’nin tanısı, tedavisi ve önlenmesine yönelik bir uzlaşı raporu oluşturabilmek amacıyla ilgili ulusal uzmanlık kuruluşlarına bir işbirliği çağrısında bulunmuştur.

Anahtar sözcükler: Tanı, endokardit, önleme, tedavi.

Received: December 18, 2019 Accepted: January 06, 2020 Published online: January 23, 2020

Correspondence: Serap Şimşek-Yavuz, MD. İstanbul Üniversitesi İstanbul Tıp Fakültesi Enfeksiyon Hastallıkarı ve Klinik Mikrobiyoloji Anabilim Dalı, 34093 Fatih, Istanbul, Türkiye. Tel: +90 505 - 2696412 e-mail: serapsimsekyavuz@gmail.com

Cite this article as:

Şimşek-Yavuz S, Akar AR, Aydoğdu S, Berzeg-Deniz D, Demir H, Hazırolan T, et al. Consensus Report on Diagnosis, Treatment and Prevention of Infective Endocarditis by Turkish Society of Cardiovascular Surgery (TSCVS), Turkish Society of Clinical Microbiology and Infectious Diseases (KLIMIK), Turkish Society of Cardiology (TSC), Turkish Society of Nuclear Medicine (TSNM), Turkish Society of Radiology (TSR), Turkish Dental Association (TDA) and Federation of Turkish Pathology Societies (TURKPATH) Cardiovascular System Study Group. Turk Gogus Kalp Dama 2020;28(1):2-42

* Full text of this report was published in "Klimik Dergisi 2019;32: Özel Sayl-1:2-116."

https://www.klimikdergisi.org/tr/infektif-endokarditin-tanisi-tedavisi-ve-onlenmesi-ulusal-uzlasi-raporu-165880 This is a summary of the original full-text article. 
Although infective endocarditis (IE) is rare, it is still essential as an infectious disease due to the resulting morbidity and substantial mortality rates. Epidemiological studies in developed countries have shown that the incidence of IE has been approximately $6 / 100,000$ in recent years, and it is on the fourth rank among the most life-threatening infectious diseases after sepsis, pneumonia, and intraabdominal infections. Although IE is not a mandatory reportable disease in Turkey and an incidence study has not been performed, its incidence may be expected to be higher due to both more frequent presence of predisposing cardiac conditions and higher rates of nosocomial bacteremia which may lead to IE in risk groups. Additionally, IE often affects elderly in developed countries, while it still affects young individuals in Turkey. To reduce mortality and morbidity, it is critical to diagnose IE to determine the causative agent and to start treatment rapidly. However, most of the patients cannot be diagnosed in their first visits, about half of them can be diagnosed after three months, and the disease often goes unnoticed. In patients diagnosed with IE, the rate of identification of causative organisms is more than $90 \%$ in developed countries, while it is around $60 \%$ in Turkey.

Furthermore, some essential microbiological diagnostic tests are not performed in most of the centers. Some antimicrobials recommended as the first option for treatment of IE, particularly antistaphylococcal penicillins, are unavailable in Turkey. ${ }^{[1-18]}$ These problems necessitate reviewing the epidemiological, laboratory, and clinical characteristics of IE in our country, as well as the current information about its diagnosis, treatment, and prevention with local data. Physicians can follow patients with IE in many specialties. Diagnosis and treatment processes of IE should be standardized at every stage so that management of IE, a setting in which many physicians are involved, can be always in line with current recommendations. From this point of view, the Study Group for Infective Endocarditis and Other Cardiovascular Infections of the Turkish Society of Clinical Microbiology and Infectious Diseases has called for collaboration of the relevant specialist organizations to establish a consensus report on the diagnosis, treatment, and prevention of IE in the light of current information and local data in Turkey. In the periodic meetings of the assigned representatives from all the parties, various questions were identified. Upon reviewing related literature and international guidelines, these questions were provided with consensus answers.

\section{Why was this consensus report written?}

Infective endocarditis often affects elderly individuals in developed countries; however, it still affects young individuals in Turkey. It is one of the most life-threatening infectious diseases and is among the infectious disease leading to mortality frequently in the population. Compared to the European countries and the United States, patients with IE are younger, predisposing factors are different, identification rates of IE pathogens are lower, accessing to some essential diagnostic tests are not possible or hardly possible, some of the antimicrobials recommended for treatment are not available in our country. Therefore, European and American diagnostic and treatment guidelines do not meet our requirements, and this causes a need to prepare a national consensus report for IE..$^{[1-18]}$

\section{EPIDEMIOLOGY OF IE IN TURKEY AND GLOBALLY}

\section{What is the incidence of IE in our country and globally?}

The incidence of IE is approximately $6 / 100,000$ people worldwide. There are no data about the incidence of IE in Turkey, which is predicted to be higher in our country due to higher incidences of both valvular diseases and nosocomial bacteremia. ${ }^{[19-51]} \mathrm{A}$ comparison of epidemiological features of IE cases between Turkey and USA/Europe is shown in Table 1.

Which patient populations have a higher risk of developing IE in Turkey and globally?

Infective endocarditis is more frequently seen in patients with a previous episode of IE, a valvular heart disease, a congenital heart disease, any intracardiac prosthetic material, intravenous drug use (IVDU), chronic hemodialysis treatment, solid organ, and hematopoietic stem cell transplantation, compared to healthy population. ${ }^{[2,4,5,23,27-31,45,50,52-84]}$ The incidence of IE among risk groups is shown in Table 2.

Which are the most frequently identified microorganisms that cause IE in Turkey and globally?

The most frequent causative microorganisms in order are Staphylococcus aureus (S. aureus), streptococci, coagulase-negative staphylococci (CoNS), and Enterococci both in Turkey and globally. Additionally, Brucella spp. is the fifth most common causative agent of IE in Turkey (Table 1). Coxiella burnetii, which is one of the leading causes of blood culture-negative IE globally, has been identified in some case reports from 


\begin{tabular}{|c|c|c|}
\hline Feature & Turkey & USA/Europe \\
\hline Age, year (mean) & 47 & 61 \\
\hline Male $(\%)$ & 60 & 65 \\
\hline \multicolumn{3}{|l|}{ Predisposing conditions } \\
\hline Acute rheumatic fever $(\%)$ & 37 & 1.85 \\
\hline Prosthetic valve (\%) & 28 & $10-30$ \\
\hline Intravenous drug user (\%) & 2 & 24 \\
\hline Cardiac implantable electronic device (\%) & 7 & 15 \\
\hline Chronic hemodialysis $(\%)$ & 9 & 13 \\
\hline \multicolumn{3}{|l|}{ Causative microorganisms } \\
\hline Staphylococcus aureus (\%) & 21 & 32 \\
\hline Viridans group streptococci & 19 & 18 \\
\hline Coagulase-negative staphylococci & 10 & 11 \\
\hline Enterococcus spp. & 9 & 11 \\
\hline Brucella spp. & 7 & - \\
\hline Blood culture-negative & 37 & 8 \\
\hline Nosocomial endocarditis & 25 & 25 \\
\hline Mortality & 24 & 19 \\
\hline
\end{tabular}

\begin{tabular}{|lc|}
\hline \multicolumn{2}{|l|}{ Table 2. The incidence of infective endocarditis among risk groups } \\
\hline Predisposing condition & Incidence (per 100,000 population) \\
\hline General population & 6 \\
\hline Mean age (years) & 12 \\
\hline$>70$ & 19 \\
\hline$>75$ & 348 \\
\hline Structural heart valve diseases & 48 \\
\hline Rheumatic or degenerative heart valve diseases & \\
\hline Mitral valve prolapse (regurgitating) & 480 \\
\hline Congenital heart diseases & 66 \\
\hline Ventricular septal defect (small) & \\
\hline Bicuspid aortic valve & $>1,000(2,800)$ \\
\hline Intracardiac foreign body & $>1,000$ \\
\hline Prosthetic valve & 1,000 \\
\hline Transcatheter aortic valve implantation & 7,300 \\
\hline Permanent pace-maker/intracardiac defibrillator & \\
\hline Previous infective endocarditis & 627 \\
\hline Patient with renal failure & 1,092 \\
\hline End-stage chronic renal failure & 1,125 \\
\hline Hemodialysis & 1,350 \\
\hline Intravenous drug user & \\
\hline Solid organ transplant recipient & \\
\hline
\end{tabular}


our country and, therefore, it must be in the differential diagnosis. Although Bartonella spp. and Tropheryma whipplei are frequently the causes of blood culturenegative IE globally, and there are no available data about these causative agents in Turkey. The research concerning these agents should be performed. Gramnegative bacilli and fungi are often causative agents of healthcare-associated IE. In patients who underwent implantation of intracardiac prosthetic devices such as prosthetic heart valves in the last decade, Mycobacterium chimaera should be kept in mind as a possible pathogen for blood culture-negative IE..$^{[4,82,85-127]}$

\section{PATHOGENESIS OF IE}

\section{What is the pathogenesis of IE?}

Mechanical injury on the endocardial surface consequently leads to non-bacterial thrombotic endocarditis (NBTE) formation on which bacterial adhesion occurs on its surface during transient bacteremia. The vegetation enlarges and becomes mature by bacterial proliferation, deposition of fibrinogen, and platelet aggregation. $S$. aureus may bind directly to an inflamed, but structurally intact endocardial surface and be ingested by endothelial cells causing cellular tissue lysis and damage. These damaged cells induce the release of tissue factor and cytokines, causing blood clotting and promoting the extension of inflammation and vegetation formation ${ }^{[21,27,86,128-136]}$

\section{DIAGNOSIS OF IE}

What are the clinical features in patients with IE, and which clinical signs should lead to the suspicion of IE?

Acute IE must be in the differential diagnosis in patients admitted to the emergency room with fever who have predisposing factors for IE (i.e., valvular heart diseases, intracardiac prosthetic devices including a prosthetic valve or IVDU or chronic hemodialysis). In addition, patients who have sepsis with an unknown source, peripheral embolism, multiple infectious foci of sepsis, and new-onset murmurs should also evaluated for acute endocarditis.

Either subacute and chronic IE must be kept in mind in the differential diagnosis of patients with unexplained fever, fatigue, weight loss, and increased acute phase reactants; unexplained arterial embolism including central nervous system and pulmonary; unexplained heart and valvular failures; unexplained blood culture positivity, particularly if they have a predisposing condition for IE. ${ }^{[4,14,23,137-143]}$

\section{What are the laboratory findings of IE?}

Continuous bacteremia causes continuous intravascular stimulation which consequently leads to acute phase responses to the causative agent, excessive production of both antibodies, and immune complexesin patients with IE. Some laboratory test results may be either lower or higher than the normal range due to either sepsis or organ failures caused by the disease itself. ${ }^{[144-172]}$

Which echocardiographic methods should be used in the diagnosis of IE and what is the appropriate timing to do it?

Transthoracic echocardiography (TTE) must be performed for all patients with suspected IE as soon as possible. Transesophageal echocardiography (TEE) must be performed in case of negative TTE, when there is a high index of suspicion for IE, mainly when TTE is of suboptimal quality. Transthoracic echocardiography should be also performed in patients with prosthetic valves or intracardiac prosthetic devices. ${ }^{[3,65,66,141,173-183]}$

What are the echocardiographic findings leading to the diagnosis of IE?

Vegetation, abscess, pseudoaneurysm or intracardiac fistula, valvular aneurysm or perforation, new partial dehiscence of the prosthetic valve, and new or worsening valvular regurgitation are the echocardiographic findings and images which causes suspicion of IE. ${ }^{[3,65,66,141]}$

What are the sensitivities and specificities of the echocardiographic examinations for the diagnosis of IE?

The sensitivity of TTE and TEE in the detection of vegetations in IE patients is $70 \%$ and $96 \%$ and $50 \%$ and $92 \%$ in native and prosthetic valves, respectively. Both modalities have a specificity of $90 \%$ for the detection of vegetation. ${ }^{[173]}$

What is the role of echocardiography in the determination of response to treatment and during follow-up of IE?

While the size and mobility of the vegetations are expected to decrease with effective antimicrobial treatment, an increase in vegetation size should be taken into account as a risk factor for a new embolic event. It is challenging to interpret persisting and unchanging vegetation size. In such cases, the patient should be evaluated carefully with other clinical and laboratory findings. Well-timed echocardiography is of vital importance to identify patients with signs and 
symptoms (i.e., shortness of breath, rhythm conduction disorders) of a cardiac complication (i.e., heart failure, valvular regurgitation, abscess formation, aneurysm or perforation) requiring an emergent surgery. ${ }^{[3,173-186]}$

When should cardiac computed tomography (CT) be performed in patients with suspected IE, and what are the advantages and disadvantages of cardiac CT?

Although cardiac CT has the advantage of providing more information about cardiac anatomy (anatomy of the pseudoaneurysm, abscess, fistula, and perivalvular extension), it is inferior to TEE in the detection of vegetation. Cardiac CT should be performed in high suspicion of either native or prosthetic valve endocarditis in case of TEE negativity. ${ }^{[65,175,187,188]}$

When should magnetic resonance imaging (MRI) be performed in patients with suspected IE, and what are the advantages and disadvantages of MRI?

The experience with cardiac MRI to define cardiac pathologies in patients with IE is limited. Nevertheless, existing evidence suggests that cardiac MRI can be an excellent option to evaluate cardiac anatomy such as cardiac CT, and further studies are needed. Currently, MRI is often used to visualize intracranial complications in patients with neurological symptoms. Cranial MRI should be the diagnostic choice for IE patients with neurological symptoms as its sensitivity is higher than cranial CT in the detection of cranial lesions. ${ }^{[65,189-190]}$

When should 18F-fluorodeoxyglucose (FDG) positron emission tomography (PET)/CT imaging be performed in patients with suspected IE, and what are the advantages and disadvantages of 18F-FDG PET/CT?

18F-FDG PET/CT can be used to confirm the diagnosis by identifying both valvular and paravalvular lesions in patients with the suspicion of prosthetic valve endocarditis after the first three postoperative months in whom TEE is negative. 18F-FDG PET/CT can be also used to define septic foci outside the heart, both in native and prosthetic valve endocarditis. The most important advantages of this modality are to define infectious foci both inside and outside the heart, to establish useful data, and to monitor response to treatment. The false-positivity, particularly within the first three postoperative

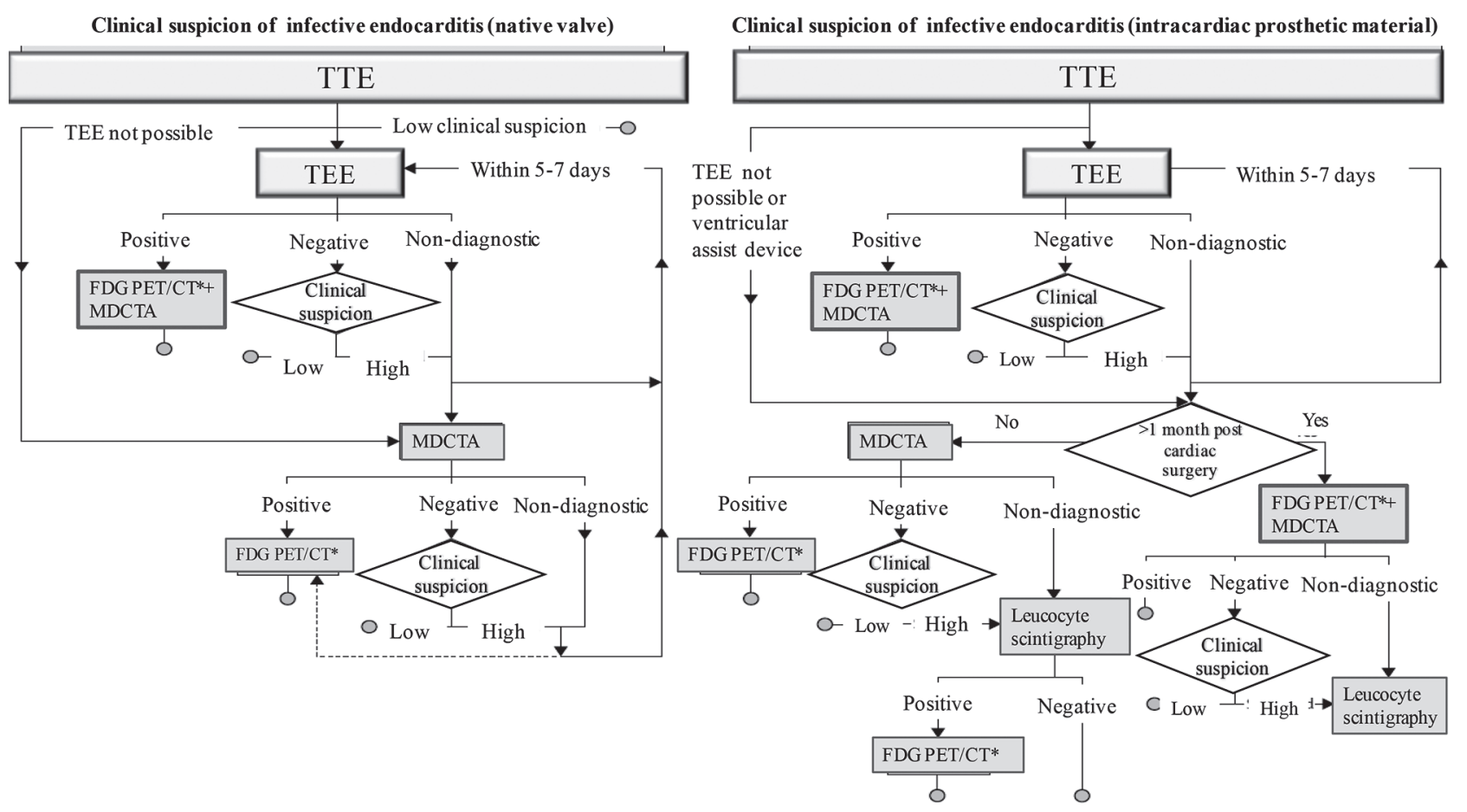

Figure 1. Flowchart for the diagnostic imaging workup of patients suspected of infective endocarditis. ${ }^{[176]}$

FDG: Fluorodeoxyglucose; PET: Positron emission tomography; MDCTA: Electrocardiogram-gated multidetector CT angiography. TTE: Transthoracic echocardiogram; TEE: Transesophageal echocardiogram. Circles indicate the end of a diagnostic pathway, when efforts to diagnose (extracardiac complications of) infective endocarditis can be ceased; * Allocation specifically for the detection of extracardiac foci. 
months in early prosthetic valve endocarditis and its lower sensitivity to diagnose intracardiac pathologies in native valve endocarditis, are the disadvantages of 18F-FDG PET/CT. ${ }^{[175,191-197]}$

When radiolabeled leukocyte scintigraphy with single-photon emission computed tomography (SPECT)/CT should be done in patients with suspected IE, and what are the advantages and disadvantages of it?

Radiolabeled leukocyte scintigraphy with SPECT/ CT can be used as an imaging modality for the diagnosis of prosthetic valve endocarditis within the first three months of prosthesis implantation. Although scintigraphy has a higher specificity, the most significant disadvantage is its lower sensitivity. ${ }^{[65,198,199]}$

\section{What should be the algorithm for imaging modalities in the diagnosis of IE?}

Echocardiography is the first imaging modality of choice to define cardiac lesions in patients with suspected IE. Both TTE and TEE are usually necessary for almost all patients. Both are inconclusive in about $15 \%$ of all IE cases, whereas this rate increases up to $30 \%$ in patients with intracardiac prosthetic devices such as a prosthetic valve or cardiac implantable electronic devices (CIEDs). In these patients, cardiac $\mathrm{CT}$ should be the technique of imaging modality in patients with native valve endocarditis. In contrast, cardiac CT or SPECT/CT should be chosen for patients who have prosthetic valve endocarditis within the first one to three months of valve surgery and cardiac $\mathrm{CT}$ and PET/CT should be chosen for patients with

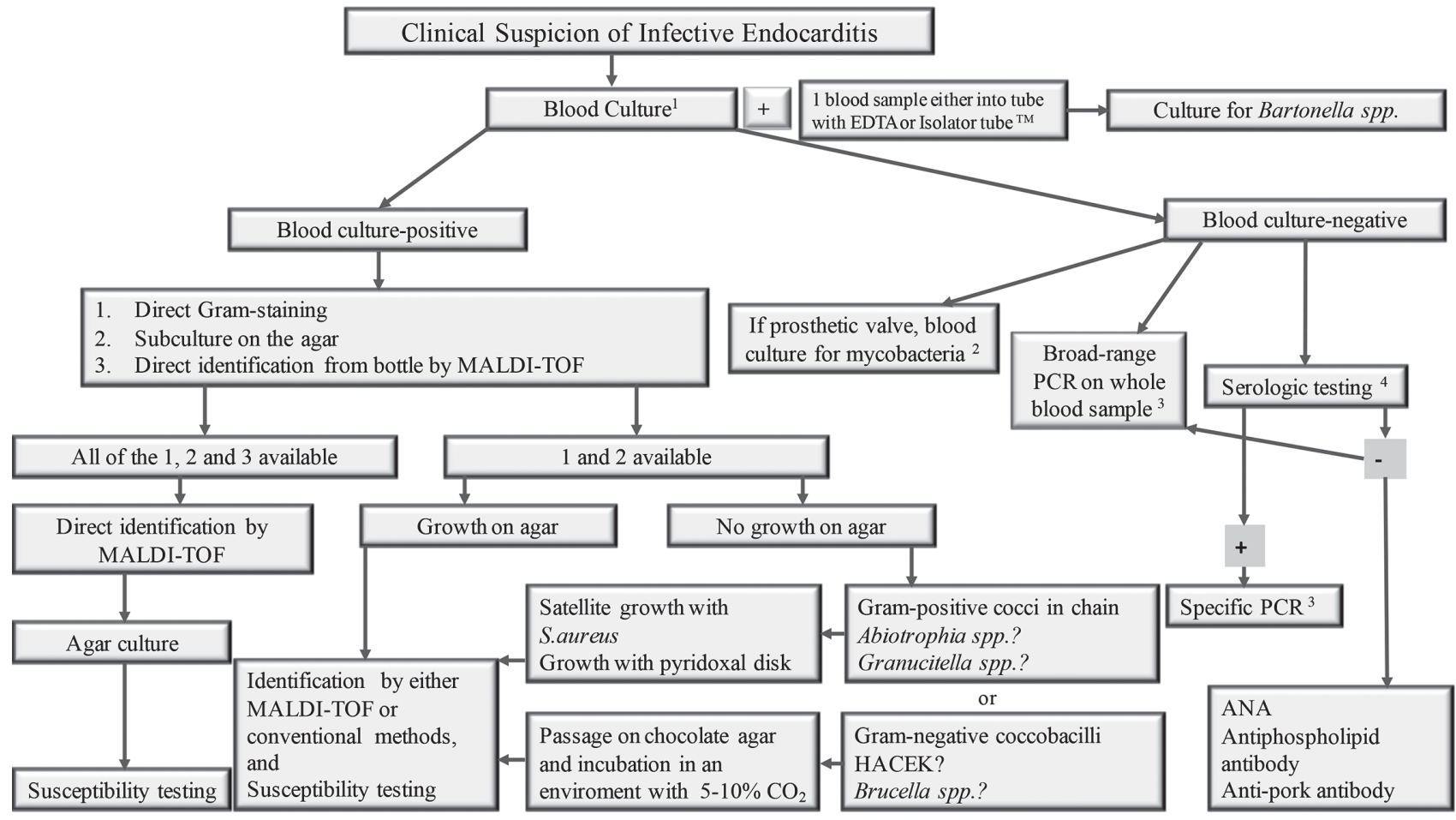

Figure 2. Diagnostic testing algorithm for the identification of the microbiological etiology of IE.

EDTA: Ethylene-diamine-tetra acetic acid; MALDI-TOF: Matrix assisted laser desorption ionization - time of flight; PCR: Polymerase chain reaction; HACEK: Haemophilus parainfluenzae, Aggregatibacter spp., Cardiobacterium spp., Eikenella corrodens and Kingella spp., ANA: Antinuclear antibody; IFA: Indirect immunofluorescence assay; MIC: Minimum inhibitory concentration.

1 Blood cultures: Three sets of blood cultures (a total of 6 bottles each inoculated with $10 \mathrm{~mL}$ of blood) collected from different venipuncture sites, with at least $1 \mathrm{~h}$ between the first and last draw.

2 In patients who are suspected of having prosthetic valve endocarditis, three additional blood culture bottles specified for mycobacterial growth (BD BACTEC ${ }^{\mathrm{TM}}$ Myco/F Lytic, etc.) should be inoculated, unless there is microbial growth in usual blood culture bottles.

3 PCR assays: Multiplex PCR tests targeting streptococci and staphylococci (LightCycler ${ }^{\circledast}$, SeptiFast, etc.) or broad-range bacterial (16S rRNA) or fungal (18S rRNA) PCR followed by sequencing (SepsiTest ${ }^{\circledR}$, etc.) should be done for patients with blood culture negative endocarditis and who had taken antibiotics before admission. For patients with a positive serological test results, organism-specific PCR targeting that specific organism should be done

4 Serologic testing: Wright agglutination test with Coombs serum or Brucellacapt ${ }^{\circledR}$ test, Coxiella burnetii phase I IgG, Bartonella quintana IgG and B. henselae IgG should be ordered first. If those test results were found to be negative, then Legionella spp. IgG, Mycoplasma spp. IgG, Chlamydophila pneumoniae IgG and galactomannan antigen for Aspergillus spp. should be investigated in the serum. Interpretation of serological test results: C. burnetii phase I IgG antibodies $>1 / 800$, Bartonella spp. IgG antibodies $>1 / 800$, C. pneumoniae IgG antibodies $>1 / 512$ and Legionella spp. IgG antibodies $>1 / 256$, Wright agglutination test $>1 / 160$ or Brucellacapt ${ }^{\circledR}$ IgG antibodies $>1 / 320$ and a galactomannan optical density index of $\geq 0.5$ should be considered positive. 
prosthetic valve endocarditis after three months of valve surgery. ${ }^{[65,66,173-176]}$ Flowchart for the diagnostic imaging work-up of patients suspected of IE is shown in Figure 1. ${ }^{[175]}$

\section{How should blood culture sampling be performed in patients with suspected IE?}

In patients with suspected IE, three sets of blood cultures (includes three pairs of aerobic and anaerobic bottles, six bottles in total) should be drawn at 30-min intervals without waiting for a febrile period. Each blood culture set, comprised of one aerobic and one anaerobic bottle, should be inoculated with 18 to $20 \mathrm{~mL}$ of blood (9-10 mL blood per bottle). Totally $60 \mathrm{~mL}$ of blood should be taken from one patient with suspected IE. In patients who had cardiac surgery in the last decade and are suspected of having prosthetic valve endocarditis, three additional blood culture bottles specified for mycobacterial growth should be inoculated, unless there is microbial growth in usual blood culture bottles. Two sets of control blood cultures should be repeated every 48 hours after the initiation of therapy, until blood cultures are sterile..$^{[3,65,86,119,200-207]}$
How to culture valvular tissues or embolic specimens resected during surgery for the diagnosis of IE?

The excised valvular tissue from patients with suspected IE should be evaluated both microbiologically (stains, culture, molecular techniques) and histopathologically. ${ }^{[208-210]}$

When and which serological tests should be done for the diagnosis of IE?

In patients with negative blood cultures, the Wright agglutination test (with Coomb's serum) and Coxiella phase 1 IgG test (IFA) should be performed initially. If the results of these two tests are negative, IgG antibodies for Bartonella spp., Legionella spp., Chlamydia spp., and Mycoplasma spp. should be tested, preferably by the IFA method. ${ }^{[4,111,112,210-216]}$

What are the molecular tests that could be done in either blood or tissue samples of patients with suspected IE, and when should they be on the agenda?

Multiplex polymerase chain reaction (PCR) tests $\left(\right.$ SeptiFast $^{\circledR}$, SeptiTest ${ }^{\circledR}$ ) should be used to identify

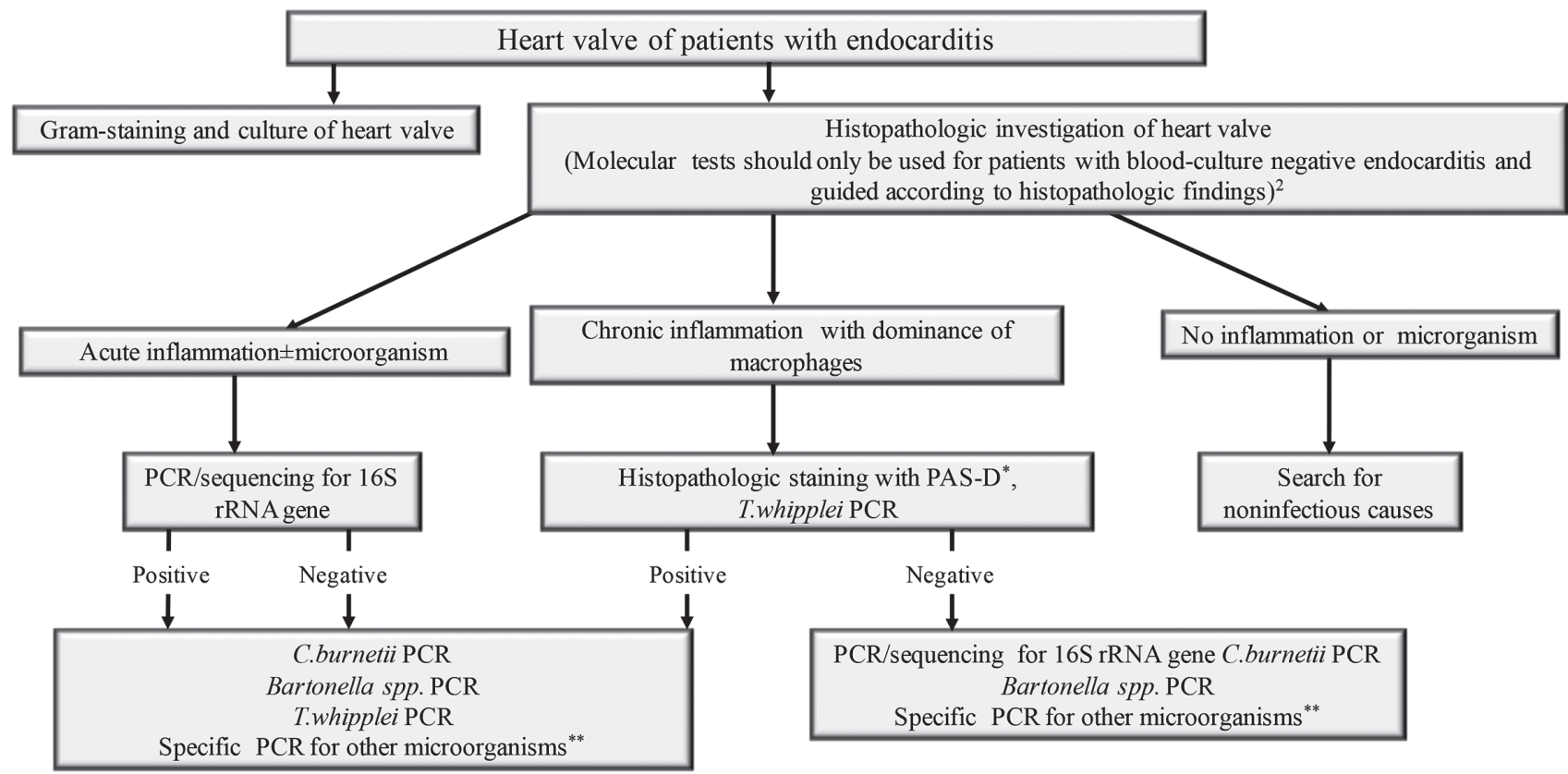

Figure 3. Microbiological and histopathological evaluation of heart valves removed from patient with endocarditis.

PCR: Polymerase chain reaction; rRNA: Ribosomal RNA; * Periodic-acid Schiff (PAS)-positive staining reaction is seen in the macrophages infected with Tropheryma whipplei; ** For example, Mycoplasma hominis, Legionella spp., Chlamydia spp., Cutibacterium (formerly Propionibacterium) acnes, etc. 
the pathogen in a whole blood specimen of patients with suspected endocarditis and whose blood cultures are negative and who has received previous antibiotic therapy. If the blood cultures are negative in patients not receiving received previous antibiotic therapy, the 16S rRNA gene and Tropheryma whipplei PCR should be, then, performed on the resected heart valve obtained during surgery. ${ }^{[140,217-225]}$

What is the contribution of histopathological examination of valvular tissue excised from patients with suspected IE?

Histopathological examination of resected valvular tissue gives valuable information about the activation and degree of the inflammation in patients with blood culture-positive endocarditis. In contrast, in blood culture-negative IE patients, it allows identifying pathogens, mainly intracellular ones like Coxiella burnetii, Bartonella spp., and Tropheryma whipplei with proper staining and immunohistochemical examinations. ${ }^{[119,138,225-232]}$ Diagnostic testing algorithms for the identification of the microbiological etiology of IE is shown in Figure 2 and Figure 3.

What are the sensitivity and specificity of modified Duke Criteria in the diagnosis of IE?

The modified Duke criteria have a sensitivity of $80 \%$ in native valve endocarditis, whereas they are insufficient in patients with prosthetic heart valves, intracardiac prosthetic devices, and blood culture-negative endocarditis. Additional imaging techniques and serological and molecular tests should be added to the diagnostic work-up of these patients. ${ }^{[65,141,233]}$ The modified Duke Criteria, including also modification of the European Society of Cardiology (ESC), is shown in Table 3 and Table 4. ${ }^{[3,65]}$

\section{How is NBTE differentiated from IE?}

Non-bacterial thrombotic endocarditis can be seen with numerous clinical entities such as malignancy, hypercoagulable states, connective tissue, and autoimmune disorders. It can be documented in approximately $1 \%$ of patients with malignancy, most frequently with pancreatic adenocarcinoma $(10 \%)$. The main clinical presentation of NBTE is thromboembolism. It is essential to differentiate NBTE from IE. The same diagnostic work-up recommended for IE should be performed. The diagnosis of NBTE is challenging. It can be diagnosed in patients with the presence of a disease process known to be associated with NBTE with high suspicion, if there is the presence of multiple systemic embolism, fixed vegetation size despite antibiotic therapy, and a new heart murmur. In patients with underlying comorbidities which predispose to NBTE, the presence of heart murmur, the persistence of vegetation despite appropriate antibiotic therapy, multiple systemic embolism should lead to suspicion of the NBTE. Although the vegetations in NBTE are often small, their roots are wide and in an irregular shape. The vegetations in

\begin{tabular}{|l|}
\hline Table 3. Definition of infective endocarditis according to the modified Duke criteria ${ }^{[3,65]}$ \\
\hline Definite IE \\
Pathological criteria \\
- Microorganisms demonstrated by culture or on histological examination of a vegetation, a vegetation that has embolized, \\
- Pr an intracardiac abscess specimen; or \\
Clinical criteria \\
- 2 major criteria; or \\
- 1 major criterion and 3 minor criteria; or \\
- 5 minor criteria \\
Possible IE \\
- 1 major criterion and 1 minor criterion; or \\
- 3 minor criteria \\
\hline Rejected IE \\
- Firm alternate diagnosis; or \\
- Resolution of symptoms suggesting IE with antibiotic therapy for $\leq 4$ days; or \\
- No pathological evidence of IE at surgery or autopsy, with antibiotic therapy for $\leq 4$ days; or \\
- Does not meet criteria for possible IE, as above. \\
IE: Infective endocarditis
\end{tabular}


Table 4. Definitions of the Terms Used in the European Society of Cardiology 2015 Modified Criteria for the Diagnosis of Infective Endocarditis ${ }^{[3,65]}$

\section{Major criteria}

\section{Blood cultures positive for IE}

a. Typical microorganisms consistent with IE from two separate blood cultures:

- Viridans streptococci, Streptococcus gallolyticus (Streptococcus bovis), HACEK group, Staphylococcus aureus; or

- Community-acquired enterococci, in the absence of a primary focus; or

b. Microorganisms consistent with IE from persistently positive blood cultures:

- $\geq 2$ positive blood cultures of blood samples drawn $>12 \mathrm{~h}$ apart; or

- All of 3 or a majority of $\geq 4$ separate cultures of blood (with first and last samples drawn $\geq 1$ h apart); or

c. Single positive blood culture for Coxiella burnetii or phase I IgG antibody titre $>1: 800$

\section{Imaging positive for IE}

a. Echocardiogram positive for IE:*

- Vegetation;

- Abscess, pseudoaneurysm, intracardiac fistula;

- Valvular perforation or aneurysm;

- New partial dehiscence of prosthetic valve.

b. Abnormal activity around the site of prosthetic valve implantation detected by 18F-FDG PET/CT (only if the prosthesis was implanted for $>3$ months) or radiolabelled leukocytes SPECT/CT.

c. Definite paravalvular lesions by cardiac CT.

\section{Minor criteria}

1. Predisposition such as predisposing heart condition, or injection drug use.

2. Fever defined as temperature $>38^{\circ} \mathrm{C}$.

3. Vascular phenomena (including those detected by imaging only): major arterial emboli, septic pulmonary infarcts, infectious (mycotic) aneurysm, intracranial hemorrhage, conjunctival hemorrhages, and Janeway's lesions.

4. Immunological phenomena: glomerulonephritis, Osler's nodes, Roth's spots, and rheumatoid factor.

5. Microbiological evidence: positive blood culture but does not meet a major criterion as noted above or serological evidence of active infection with organism consistent with IE.

* Although it is was not included in the ESC 2015 Modified Duke Criteria, "new valvular regurgitation (Worsening or changing or pre-existing murmur not sufficient)" was included as a major echocardiographic criterion in the original Modified Duke Criteria (3).

NBTE show minimal inflammation where they are attached. ${ }^{[131,234-236]}$

\section{PROGNOSTIC ASSESSMENT OF PATIENTS WITH IE AT ADMISSION AND DURING FOLLOW-UP}

When should the prognostic assessment be done in IE patients, and what is the benefit of this assessment?

A prognostic risk assessment should be done in patients with suspected IE using the Simplified Risk Scoring System during their first evaluation (Table 5 and Table 6). The patients with a higher mortality risk (risk score >8) should be carefully evaluated on time for urgent surgery and transfer possibility to a reference center and intensive care unit (ICU). Prognostic assessment of a patient with IE should be performed thrice: at admission, within the first week of the start of antibiotic therapy, and before discharge. Predicting the prognosis of IE helps clinicians to make an effort to prevent possible complications and to be prepared to overcome these complications. ${ }^{[65,66,237-240]}$

\section{THE IE TEAM IN THE MANAGEMENT OF PATIENTS}

What is the IE Team, and why is there a necessity for making up such a team?

The IE team is a multidisciplinary team including representatives of relevant specialties who manage the diagnosis and treatment of all IE patients, decide collaboratively on all aspects of the disease, particularly on antimicrobial and surgical treatment and meet once a week or, when needed more frequently, to regularly follow-up and evaluate patients. Patients with IE can be followed by physicians from several specialties, as the disease has a wide range of clinical presentations. Since it is a rare disease, it is also unlikely that each 
Table 5. Simplified Risk Score Calculation for 6-Month Mortality in Infective Endocarditis (IE) ${ }^{[237]}$

\begin{tabular}{|l|c|}
\hline Prognostic variable & Weight \\
\hline Age (year) & 0 \\
\hline 445 & +2 \\
\hline $61-70$ & +3 \\
\hline$>70$ & +4 \\
\hline History of dialysis & +3 \\
\hline Nosocomial IE & +2 \\
\hline Prosthetic valve IE & +1 \\
\hline Symptoms $>1$ month before admission & -1 \\
\hline Staphylococcus aureus as causative agent & +1 \\
\hline Viridans group streptococci as causative agent & -2 \\
\hline Aortic vegetation & +1 \\
\hline Mitral vegetation & +1 \\
\hline NYHA class 3 or 4 heart failure caused by IE & +3 \\
\hline Stroke & +2 \\
\hline Paravalvular complications & +2 \\
\hline Persistent bacteremia & +2 \\
\hline Surgical treatment for IE & -2 \\
\hline
\end{tabular}

physician has sufficient experience. All these features drive to the delayed diagnosis and treatment of the disease. Consequently, the delay is associated with increased morbidity and mortality rates.

Therefore the IE teams should be established to diagnose IE, give a standardized therapy following the current guidelines, increase practitioners' knowledge and experience, and follow-up the patients with IE.

A cardiologist, a cardiovascular surgeon, and infectious diseases and clinical microbiology specialists should be present in the IE team, at least. When needed, a neurologist, a radiologist, a nuclear medicine specialist, a pathologist, and a neurosurgeon should join the IE team in referral centers. It has been shown that a multidisciplinary approach decreases morbidity and mortality of IE patients. These patients complicated with heart failure, abscess, neurological complications should be followed in referral centers where there are neurosurgery and cardiac surgery facilities. Uncomplicated cases can be followed in non-reference centers provided that there is close communication with the reference centers, and patients are evaluated by the IE team regularly and should be referred to these centers, when necessary (Table 7 and Table 8). ${ }^{[65,241-245]}$
Table 6. Probability of 6-Month Mortality in Patients with Infective Endocarditis According to Simplified Risk Score ${ }^{[237]}$

\begin{tabular}{|l|c|}
\hline Total risk score & $\begin{array}{c}\text { Probability of 6-month } \\
\text { mortality }(\%)\end{array}$ \\
\hline $0-6$ & $8-12$ \\
\hline $7-8$ & $16-20$ \\
\hline $9-10$ & $30-34$ \\
\hline $11-16$ & $42-50$ \\
\hline $17-22$ & $>60$ \\
\hline
\end{tabular}

\section{ANTIMICROBIAL TREATMENT OF IE}

What are the general principles of antimicrobial treatment of in IE, and how should the duration of treatment be determined?

The bactericidal agents given parenterally for long duration is the general principle of antimicrobial treatment of IE. The duration of the antimicrobial treatment is determined by several factors, including the pathogen, the presence of prosthetic material, and the duration of symptoms. The therapy duration is often four to six weeks for native valve endocarditis and longer than six weeks for prosthetic valve endocarditis. ${ }^{[3,86,140,246,247]}$

Is oral antibiotic therapy feasible to use in the treatment of left-sided endocarditis?

Since there are questions about the feasibility and efficacy of oral antimicrobial treatment of left-sided endocarditis in our country and since left-sided endocarditis is related to a substantially higher mortality rate, the parenteral route should be preferred for the complete duration of antimicrobial treatment of left-sided endocarditis in Turkey. In case of unavailability of IV access or outpatient parenteral antibiotic therapy, oral therapy may be feasible to complete the therapy duration in stable patients with uncomplicated native valve endocarditis as a result of drug-susceptible viridans group Streptococci. Probability of compliance and follow-up is not going to be a problem, provided that initial two weeks of antibiotic therapy completed parenterally, the patient is informed about all the possible risks and give informed consent. Switching to oral therapy should be a joint decision of the IE team. ${ }^{[248-251]}$

\section{Is empirical treatment necessary for IE?}

Antibiotic therapy should be initiated without any delay, as it reduces not only the risk of an embolic event in patients with either acute or subacute IE, but 


\section{Table 7. Department of hospitalization for patients with infective endocarditis}

Patient's condition

Department of hospitalization

Patients with unstable hemodynamic condition, or severe valve dysfunction, or within the first days of Staphylococcus aureus endocarditis

Patients with stable hemodynamic status and good valve function Intensive care unit or coronary intensive care unit

Patients with indication for emergent surgery

Patients with an indication for urgent/elective surgery

Patients without any surgical indications

\begin{tabular}{l} 
Cardiology \\
\hline Infectious Disease and Clinical Microbiology \\
Cardiovascular surgery \\
\hline Cardiology \\
\hline Infectious Disease and Clinical Microbiology \\
\hline Cardiology \\
\hline Infectious Disease and Clinical Microbiology
\end{tabular}

\section{Table 8. Approach to the patient with suspected endocarditis}

Recommendations

Determination of patient's hemodynamic status and decision for place of hospitalization accordingly

Prediction of prognosis according to simplified risk score and referral of the patients with a score of $\geq 8$ to the reference centre

TTE

Timing

TEE

When TTE is of suboptimal quality or complications are suspected Other conditions

Immediately

In the first 24 hours or after getting the results of blood cultures and weekly

Immediately

Immediately

In the first 48 hours

Whole blood count, serum CRP, ESR, procalcitonin, BUN, creatinine, urine analysis, ALT, AST, glucose, NT-pro-BNP and cTnI levels

Three-sets of blood cultures

Immediately

Within the first hour (at $0 ., 30^{\text {th }}$ and $60^{\text {th }}$ minutes)

Collection of blood samples in to three plain tubes and 1 EDTA tube

- Sending of the first plain tube of blood to the laboratory for RF, ANA and Wright agglutination testing

- Sending of the second plain tube of blood to the laboratory for Coxiella burnetii phase I IgG testing

- Sending of third plain tube and first EDTA tube of blood to the laboratory for multiplex and specific PCR testing and other serological antibody testing

\section{ECG}

Repeating blood cultures in patients with a history of antibiotic usage in the previous 10 days and stable general condition

Fundoscopic examination Classification of the diagnosis according to Modified Duke Criteria

Abdominal USG

Cardiac CT, MRI, 18F-FDG PET/CT, SPECT/CT with scintigraphy with labelled leukocyte

In the first 24 hours

In the case of blood cultures negativity

In the case of blood cultures negativity Immediately

72 hours after discontinuation of antibiotics

In the first 48 hours

In the first 5 days

In the case of persistent fever and searching for a minor Duke criterion In the first 7 days

In patients with inconclusive echocardiographic results and suspected IE

In the first 7 days

TTE: Transesophageal echocardiography; CRP: C-reactive protein; ESR: Erythrocyte sedimentation rate; BUN: Blood urea nitrogen; ALT: Alanine aminotransferease; AST: Aspartate aminotransferase; NT-pro-BNP: NT-pro B-type natriuretic peptide; cTnI: Cardiac troponin I; EDTA: Ethylene-diamine-tetra acetic acid; ANA: Antinuclear antibody; PCR: Polymerase chain reaction; ECG: Electrocardiogram; USG: Ultrasonography; CT: Computed tomography; MRI: Magnetic resonance imaging; 18F-FDG: 18F-Fluorodeoxyglucose; PET: Positron emission tomography; SPECT: Single-photon emission computed tomography. 
also decreases mortality associated with sepsis in patients with acute IE. Therefore, empirical antibiotics should be promptly initiated after blood cultures are taken. ${ }^{[3,65,140,205,246,252]}$

What are the empirical drugs of choice for native, early and late prosthetic valve IE in adults in our country?

Ampicillin-sulbactam \pm gentamicin can be initiated empirically in the treatment of communityacquired, with both subacute and chronic courses of native and late prosthetic valve endocarditis, whereas vancomycin+ampicillin-sulbactam (or ceftriaxone) \pm gentamicin can be the choice for the acute course. Vancomycin+cefepime \pm gentamicin combination can be initiated empirically in the treatment of nosocomial native, early, and late prosthetic valve endocarditis. Gentamicin should be avoided in patients with initial impaired renal function. Rifampin can be also added to the empirical treatment of early prosthetic valve endocarditis. Daptomycin alone is not a drug of choice for the initial empirical treatment of IE due to its suboptimal efficacy for Streptococci and Enterococci and the ease development of resistance in these strains during treatment (Table 7). ${ }^{[3,65,137,205,253-258]}$

What are the drugs of choice in the treatment of streptococcal native and prosthetic valve endocarditis Turkey?

The decision of treatment in streptococcal IE is made according to penicillin $\mathrm{G}$ minimum inhibitory concentration (MIC) values of the pathogen. The first treatment of choice is penicillin $G$ in strains that are sufficiently sensitive to penicillin G, penicillin+gentamicin in relatively resistant strains, and vancomycin or teicoplanin in resistant strains. Daptomycin is not recommended in endocarditis caused by Streptococci, which are sensitive to penicillin and vancomycin, due to the possibility of development of resistance during treatment. ${ }^{[4,86,205,259-268]}$

What are the drugs of choice in the treatment of enterococcal endocarditis in Turkey?

In the treatment of enterococcal endocarditis, if the strain is sensitive to ampicillin (or penicillin G), the recommended regimen is ampicillin+gentamicin or ampicillin+ceftriaxone (if the strain is Enterococcus faecalis). The recommended regimen is vancomycin or teicoplanin+gentamicin, if the strain is resistant to ampicillin. Daptomycin+ampicillin+gentamicin combination is recommended if it is resistant to ampicillin, vancomycin, and teicoplanin. Gentamicin should take part in the treatment unless there is a high level of gentamicin resistance. . $\left.^{[1-4,65} 205,269-282\right]$
What are the drugs of choice in the treatment of staphylococcal endocarditis in Turkey?

Cefazolin is the drug of choice in methicillinsensitive Staphylococcus aureus (MSSA) IE in Turkey since anti-staphylococcal penicillins are not available in the domestic market. In patients with CNS septic embolism, vancomycin+cefazolin or cefotaxime should be preferred. Daptomycin should be chosen in patients who have hypersensitivity reactions such as anaphylaxis to $\beta$-lactam agents. Vancomycin in combination with cefazolin may be given to patients who are in risk groups for methicillin-resistant Staphylococcus aureus (MRSA) until antimicrobial susceptibility test results are achieved. Following test results indicating MSSA, treatment should be continued with cefazolin. Adding rifampicin and gentamicin is not recommended in native valve IE. In the prosthetic valve IE, cefazolin+gentamicin and rifampicin combination is recommended.

In MRSA IE, if MIC is $\leq 2 \mu \mathrm{g} / \mathrm{mL}$, vancomycin is recommended. Loading doses of vancomycin should be used, particularly for septic patients, followed by daily doses modified according to serum levels, the patient's weight, and renal functions. If vancomycin MIC is $>2 \mu \mathrm{g} / \mathrm{mL}$, daptomycin is recommended at doses of 8 to $12 \mathrm{mg} / \mathrm{kg} /$ day, which is determined according to its MIC values, in combination with cephazolin or trimethoprim-sulfamethoxazole. In patients with MRSA IE, particularly in whom there is persistent bacteremia ( $>3$ to 7 days), the combined vancomycin-cefazolin regimen can be used. In MRSA prosthetic valve IE, if they are sensitive, rifampicin and gentamicin should be added to vancomycin treatment. When there is resistance to these agents, ciprofloxacin can be used as an alternative, if it is sensitive. [3,4,65,86,104,205,259,269,283-355]

\section{THE COMPLICATIONS OF IE AND THEIR MANAGEMENT}

What are the clinical and laboratory signs of heart failure developing in patients with IE, and how can they be managed?

Nearly half of the left-sided IE cases, particularly those with aortic valve involvement, develop heart failure in which the mortality risk is higher compared to the right side. Dyspnea, pulmonary edema, hypotension, and other organs' dysfunction in patients with IE can be alarming for heart failure. In IE patients with heart failure, urgent surgery drops mortality rates significantly ${ }^{[81,169,173,180,356-364]}$ 
Table 9. Empirical antimicrobial treatment of infective endocarditis ${ }^{[3,65,137,205,368] *}$

\begin{tabular}{|c|c|c|c|c|c|}
\hline \multirow[b]{2}{*}{ Type of infective endocarditis } & \multirow[b]{2}{*}{ Antimicrobial agent } & \multirow[b]{2}{*}{ Dosage and route } & \multicolumn{2}{|c|}{ Duration (weeks) } & \multirow[b]{2}{*}{ Comment } \\
\hline & & & Native & $\begin{array}{l}\text { Prosthetic } \\
\text { valve }\end{array}$ & \\
\hline \multirow{2}{*}{$\begin{array}{l}\text { Native valve and late } \\
\text { prosthetic valve ( }>1 \text { year), } \\
\text { community acquired } \\
\text { endocarditis, subacute course }\end{array}$} & Ampicillin-sulbactam + & $\begin{array}{l}12 \mathrm{~g} / \text { day** i.v. } \\
\text { in } 4-6 \text { doses }\end{array}$ & 4 & 6 & $\begin{array}{l}\text { Gentamicin should be avoided } \\
\text { in patients with initial high } \\
\text { serum level of creatinine }\end{array}$ \\
\hline & Gentamicin & $\begin{array}{l}3 \mathrm{mg} / \mathrm{kg} / \text { day i.v. } \\
\text { in } 1 \text { dose }\end{array}$ & 2 & 2 & \\
\hline \multirow{3}{*}{$\begin{array}{l}\text { Native valve and late } \\
\text { prosthetic valve ( }>1 \text { year), } \\
\text { community acquired } \\
\text { endocarditis, acute course }\end{array}$} & Vancomycin + & $\begin{array}{l}30-60 \mathrm{mg} / \mathrm{kg} / \text { day i.v. } \\
\text { in } 2-3 \text { doses }\end{array}$ & $4-6$ & $\geq 6$ & \multirow{3}{*}{$\begin{array}{l}\text { Duration of treatment should be } \\
6 \text { and } \geq 6 \text { weeks for native and } \\
\text { prosthetic valve endocarditis, } \\
\text { respectively, especially in the } \\
\text { case of complicated IE, such as } \\
\text { with metastatic foci, etc. }\end{array}$} \\
\hline & $\begin{array}{l}\text { Ampicillin- } \\
\text { sulbactam, or }\end{array}$ & $\begin{array}{l}12 \mathrm{~g} / \text { day** i.v. } \\
\text { in } 4-6 \text { doses }\end{array}$ & $4-6$ & $\geq 6$ & \\
\hline & Ceftriaxone & $\begin{array}{l}2 \text { gr/day, i.v. } \\
\text { in } 1 \text { dose }\end{array}$ & $4-6$ & $\geq 6$ & \\
\hline \multirow{2}{*}{$\begin{array}{l}\text { Native valve and late } \\
\text { prosthetic valve ( }>1 \text { year), } \\
\text { healthcare associated } \\
\text { endocarditis }\end{array}$} & Vancomycin + & $\begin{array}{l}30-60 \mathrm{mg} / \mathrm{kg} / \text { day i.v. } \\
\text { in 2-3 doses }\end{array}$ & 4 & 6 & \\
\hline & Cefepime & $\begin{array}{c}6 \mathrm{gr} / \text { day, i.v. in } 3 \\
\text { doses }\end{array}$ & 4 & 6 & \\
\hline \multirow{2}{*}{$\begin{array}{l}\text { Native valve and late } \\
\text { prosthetic valve }(>1 \text { year }) \\
\text { endocarditis, } \beta \text {-lactam } \\
\text { allergy }\end{array}$} & Vancomycin + & $\begin{array}{l}30-60 \mathrm{mg} / \mathrm{kg} / \text { day i.v. } \\
\text { in } 2-3 \text { doses }\end{array}$ & 4 & 6 & $\begin{array}{l}\text { Gentamicin should be avoided } \\
\text { in patients with a higher risk of } \\
\text { nephrotoxicity }\end{array}$ \\
\hline & Gentamicin & $\begin{array}{l}3 \mathrm{mg} / \mathrm{kg} / \text { day i.v. } \\
\text { in } 1 \text { dose }\end{array}$ & 2 & 2 & \\
\hline \multirow{4}{*}{$\begin{array}{l}\text { Early prosthetic valve } \\
\text { endocarditis ( } \leq 1 \text { year) }\end{array}$} & Vancomycin + & $\begin{array}{l}30-60 \mathrm{mg} / \mathrm{kg} / \text { day i.v. } \\
\text { in } 2-3 \text { doses }\end{array}$ & & 6 & \\
\hline & Gentamicin + & $\begin{array}{l}3 \mathrm{mg} / \mathrm{kg} / \text { day i.v. } \\
\text { in } 1 \text { dose }\end{array}$ & 2 & & \\
\hline & Cefepime + & $\begin{array}{c}6 \text { gr/day, i.v. in } 3 \\
\text { doses }\end{array}$ & 6 & & \\
\hline & Rifampin & $\begin{array}{l}900 \mathrm{mg} / \text { day, i.v. or } \\
\text { orally in } 3 \text { doses }\end{array}$ & 6 & & \\
\hline \multirow{4}{*}{$\begin{array}{l}\text { Cardiac Implantable } \\
\text { Electronic Device (CIED) } \\
\text { related lead or valve } \\
\text { endocarditis }\end{array}$} & Vancomycin \pm & $\begin{array}{l}30-60 \mathrm{mg} / \mathrm{kg} / \text { day i.v. } \\
\text { in } 2-3 \text { doses }\end{array}$ & \multicolumn{2}{|c|}{$\begin{array}{l}\text { Antimicrobial therapy should } \\
\text { be continued for } 2-4 \text { and } 4-6 \\
\text { weeks for the lead and valve } \\
\text { endocarditis, respectively, after } \\
\text { the removal of the device. }\end{array}$} & $\begin{array}{l}\text { Addition of either gentamicin, } \\
\text { or cefepime, or meropenem } \\
\text { to vancomycin should be } \\
\text { considered especially for } \\
\text { septic patients with unstable } \\
\text { hemodynamic status. }\end{array}$ \\
\hline & Gentamicin, or & $\begin{array}{l}3 \mathrm{mg} / \mathrm{kg} / \text { day i.v. } \\
\text { in } 1 \text { dose }\end{array}$ & & & \\
\hline & Cefepime, or & $\begin{array}{c}6 \mathrm{gr} / \text { day, i.v. in } 3 \\
\text { doses }\end{array}$ & & & \\
\hline & Meropenem & $\begin{array}{c}3 \mathrm{gr} / \text { day, i.v. in } 3 \\
\text { doses }\end{array}$ & & & \\
\hline
\end{tabular}

In IE patients, what are the clinical and laboratory signs showing uncontrolled infection, and how should they be managed?

In IE patients who develop persistent infections characterized by fever and culture positivity exceeding five to 10 days or infection spreading around valve annulus forming an abscess, pseudoaneurysm, fistula, atrioventricular block despite antibiotic treatment, shows that infection is not under control. In persistent infections, repeated blood cultures, and echocardiographic examinations, imaging for different foci of infection and changing of intravascular catheters should be performed. Despite all of these, patients with persistent fever, particularly persistent blood culture positivity with no other infection source, should be 
evaluated for early valve surgery. Since recent studies have shown that blood culture positivity lasting for $>48$ to 72 hours increases mortality, early surgery for these patients may be also beneficial. ${ }^{[3,65,86,110,173,271,365-367]}$

What are the incidence and risk factors of embolic events in patients with IE? How should embolic events be managed?

About 20 to $50 \%$ of patients with IE have embolic complications in which the most critical risk factor is the size $(>10 \mathrm{~mm})$ and mobility of vegetations. This risk dramatically declines with the start of antibiotic treatment. The decision of early surgery to prevent embolism is always challenging, and each patient should be separately evaluated. The factors which influence this decision are the size and mobility of the vegetation, the existence of recurrent embolism under treatment, the type of the microorganism, and the duration of the antibiotic treatment. . $33,65,181,183,368-375]$

\section{SURGICAL TREATMENT OF IE}

What are the indications and appropriate timing of valvular surgery in the management of IE?

Urgent surgery is recommended in IE patients with heart failure. Early surgery is recommended in uncontrolled local (abscess, fistula, aneurysm) or systemic (ongoing blood culture positivity or fever with no other source) infection, recurrent embolism, large vegetations, and severe left heart valve regurgitation or stenosis without clinical signs of heart failure. If urgent surgery is indicated, starting antimicrobial treatment would be enough. There is no need to wait for the clearance of growth in blood cultures.

The decision of heart valve surgery in IE patients should be made by the IE team (or by cardiologist, cardiovascular surgeon and infectious diseases, and clinical microbiologist) by evaluating all aspects of the disease. In patients with neurological complications, surgical decision should be made by the IE team including a neurologist and a neurosurgeon according to the presence/absence of silent embolism/transient ischemic attack (TIA), ischemic stroke or hemorrhagic stroke, severity of the neurological situation and urgency of cardiovascular surgery. ${ }^{[2,3,27,65,181,376-399]}$ After a silent embolism or TIA, cardiac surgery, if indicated, is recommended without delay (Table 10 and Table 11). ${ }^{[65]}$

\section{MONITORING TREATMENT RESPONSE IN PATIENTS WITH IE AND FOLLOW- UP AFTER DISCHARGE}

\section{How should treatment response be monitored in} IE patients?

In IE patients receiving appropriate antibiotic treatment and undergoing surgical repair (when needed), fever and serum C-reactive protein (CRP) levels should decrease, blood cultures are negative,

\begin{tabular}{|c|c|c|c|}
\hline Indications & Timing & $\begin{array}{l}\text { Class of } \\
\text { recommendation }\end{array}$ & $\begin{array}{l}\text { Level of } \\
\text { evidence }\end{array}$ \\
\hline \multicolumn{4}{|l|}{ Heart failure } \\
\hline $\begin{array}{l}\text { Aortic or mitral NVE or PVE with severe acute regurgitation, } \\
\text { obstruction or fistula causing refractory pulmonary edema or } \\
\text { cardiogenic shock. }\end{array}$ & Emergency & $\mathrm{I}$ & $\mathrm{B}$ \\
\hline $\begin{array}{l}\text { Aortic or mitral NVE or PVE with severe regurgitation or } \\
\text { obstruction causing symptoms of HF or echocardiographic } \\
\text { signs of poor hemodynamic performance. }\end{array}$ & Urgent & I & $\mathrm{B}$ \\
\hline \multicolumn{4}{|l|}{ Uncontrolled infection } \\
\hline $\begin{array}{l}\text { Locally uncontrolled infection (abscess, false aneurysm, fistula, } \\
\text { enlarging vegetation) }\end{array}$ & Urgent & $\mathrm{I}$ & $\mathrm{B}$ \\
\hline Infection caused by fungi or multiresistant organisms & Urgent/elective & I & $\mathrm{C}$ \\
\hline \multicolumn{4}{|l|}{ Prevention of embolism } \\
\hline $\begin{array}{l}\text { Aortic or mitral NVE or PVE with persistent vegetations } \\
>10 \mathrm{~mm} \text { after one or more embolic episode despite appropriate } \\
\text { antibiotic therapy }\end{array}$ & Urgent & I & $\mathrm{B}$ \\
\hline
\end{tabular}




\begin{tabular}{|l|c|c|}
\hline $\begin{array}{l}\text { Table 11. Class I Indications for Surgery in Left-Sided Valve Infective Endocarditis (Recommendations from the } \\
\text { American Association for Thoracic Surgery (AATS) 2016 Consensus Guideline }{ }^{[377]}\end{array}$ & $\begin{array}{c}\text { Class of } \\
\text { recommendation }\end{array}$ & $\begin{array}{c}\text { Level of } \\
\text { evidence }\end{array}$ \\
\hline Indications & I \\
\hline $\begin{array}{l}\text { Surgery during initial hospitalization independently of the completion of a full } \\
\text { therapeutic course of antibiotics is indicated in patients with IE who present with } \\
\text { valve dysfunction resulting in symptoms of heart failure }\end{array}$ & B \\
\hline $\begin{array}{l}\text { Surgery during initial hospitalization independently of the completion of a full } \\
\text { therapeutic course of antibiotics is indicated in patients with left-sided IE caused by } \\
\text { S. aureus, fungal, or other highly resistant microorganisms }\end{array}$ & I \\
\hline $\begin{array}{l}\text { Surgery during initial hospitalization independently of completion of a full } \\
\text { therapeutic course of antibiotics is indicated in patients with IE complicated by heart } \\
\text { block, annular or aortic abscess, or destructive penetrating lesions }\end{array}$ & I & B \\
\hline $\begin{array}{l}\text { Surgery during initial hospitalization independently of the completion of a full } \\
\text { therapeutic course of antibiotics for IE is indicated in patients with evidence of } \\
\text { persistent infection as manifested by persistent bacteremia or fever lasting longer } \\
\text { than 5 to 7 days after initiation of appropriate antimicrobial therapy }\end{array}$ & I & B \\
\hline $\begin{array}{l}\text { Once an indication for surgery is established, the patient should be operated on } \\
\text { within days }\end{array}$ & I & B \\
\hline IE: Infective endocarditis. & & \\
\hline
\end{tabular}

valve functions be stabilized, vegetation size in echocardiography should not be enlarged, instead, be reduced, foci of abscess should vanish. Therefore, after starting antimicrobial treatment, two sets of blood cultures should be taken every 48 hours, until positivity in blood cultures be cleared, serial CRP measurements should be done, and gradual decrease of CRP level during treatment and reaching normal levels by the end of the treatment should be expected. The echocardiographic examination should also be performed during hospitalization and immediately before discharge. ${ }^{[65,102,400-404]}$

What recommendations should be made to IE patients at discharge?

Since the history of IE is a significant risk factor for recurrent endocarditis, patients should be informed about the probability of recurrence of the disease and signs and symptoms of the condition. They should be informed about avoiding the use of empirical antibiotics before blood cultures are collected, in case of fever, chills, and other symptoms of infection. They should be also informed about prophylaxis of endocarditis, and to avoid procedures (piercing, tattoo) that may cause bacteremia and endocarditis. ${ }^{[65]}$

How should operated/non-operated IE patients be followed in outpatient clinics?

In follow-up for detection of possible secondary heart failure, patients should be monitored with periodic TTE: on discharge as a baseline and serially in the first year. The patients should be evaluated for the late side effects of the antibiotics, particularly of aminoglycosides, used for endocarditis treatment at the hospital. Periodic follow-up should be scheduled on the first, third, sixth, and $12^{\text {th }}$ months after hospital discharge. In these outpatient follow-up visits, clinical examination, leukocyte count, CRP, and erythrocyte sedimentation rate (ESR) measurements, and TTE should be performed to detect a possible heart failure. ${ }^{[65]}$

\section{SPECIFIC CONDITIONS}

What are the critical topics in the management of patients with prosthetic valve endocarditis?

The diagnosis of prosthetic valve endocarditis is more complicated than native valve endocarditis, since both blood culture and echocardiographic examination are frequently negative. The sensitivities of TTE and TEE in the diagnosis of prosthetic valve endocarditis are $30 \%$ and $80 \%$, respectively. Infective endocarditis should be carefully investigated using novel imaging modalities such as multidetector computed tomographic angiography (MDCTA), PET/CT in patients with suspected prosthetic valve endocarditis with normal echocardiography. Surgery is frequently needed besides antibiotic treatment in patients who have heart failure or paravalvular abscess and with endocarditis caused by $S$. aureus or fungi. ${ }^{[4,65,187,405-411]}$ 
What are the critical topics in the management of IE associated with CIEDs?

A CIED-associated IE represents almost 10\% of all episodes of IE and is expected to increase proportionately to the increased number of devices implanted. Infective endocarditis should be kept in the differential diagnosis either when there is one or combination of any of the clinical presentations (fever of unknown origin, pocket infection, bacteremia with an unknown source, complications of multiple pulmonary embolisms) in patients with CIED. Blood cultures should be taken promptly; if not, TTE and TEE should investigate any findings of IE. Radiolabeled leukocyte scintigraphy or PET/CT modalities can be additive in case of a routine echocardiographic examination in the diagnosis of CIED-associated endocarditis. The specific treatment of CIED-associated endocarditis should be done with the combination of antimicrobials covering most prominent Staphylococci and complete hardware removal. Percutaneous removal of hardware must be preferred in all cases and particularly in patients with vegetation $<20 \mathrm{~mm}$ in diameter. The duration of antimicrobial therapy should be two to four weeks in patients with vegetation diagnosed at the extracted lead tip after complete hardware removal, whereas four to six weeks in patients with endocardial lesions. Blood cultures should be negative for at least 14 days to implant a new device in patients with valvular endocarditis who indicate CIED. In cases of other situations, blood cultures should be negative for at least 72 hours before the placement of a new device. To prevent CIED-related infections, a single dose of cefazolin prophylaxis just before the implantation of CIED is recommended, additional doses are not required. ${ }^{[69,70,412-432]}$ Management of suspected CIED infections, management of bacteremia without evidence of CIED infection, and management of suspected pocket infection are shown in Figures 4, 5 , and 6 , respectively.

What are the critical topics in the management of patients with non-CIED related right-sided endocarditis (IVDU)?

Right-sided endocarditis is most common among intravenous drug users (IVDUs). The incidence of IE related to IVDU is going to be increased in parallel with the increasing prevalence of IVDU in Turkey and globally. It is not necessary to make TEE as TTE

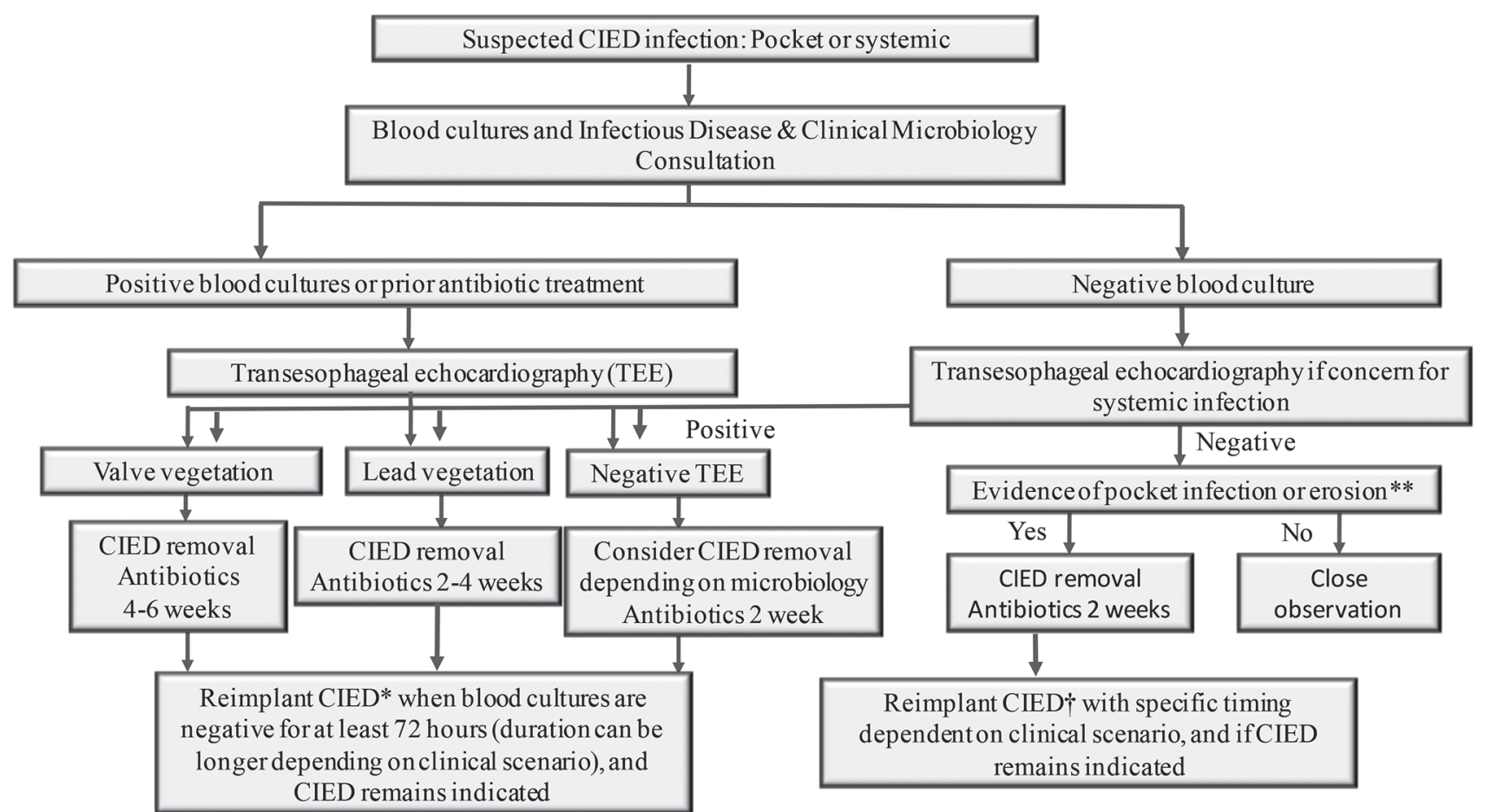

Figure 4. Management of suspected CIED infection.

CIED: Cardiac implantable electronic devices; Antimicrobial therapy should be at least 4-6 weeks for endocarditis (4 weeks for native valve, 6 weeks for prosthetic valve or staphylococcal valvular endocarditis). If lead vegetation is present in the absence of a valve vegetation, 4 weeks of antibiotics for Staphylococcus aureus and 2 weeks for other pathogens is recommended.* Usually the contralateral side; a subcutaneous ICD may also be considered; ** 2010 AHA CIED Infection Update distinguishes between pocket infection and erosion. ${ }^{[70,415]}$ 


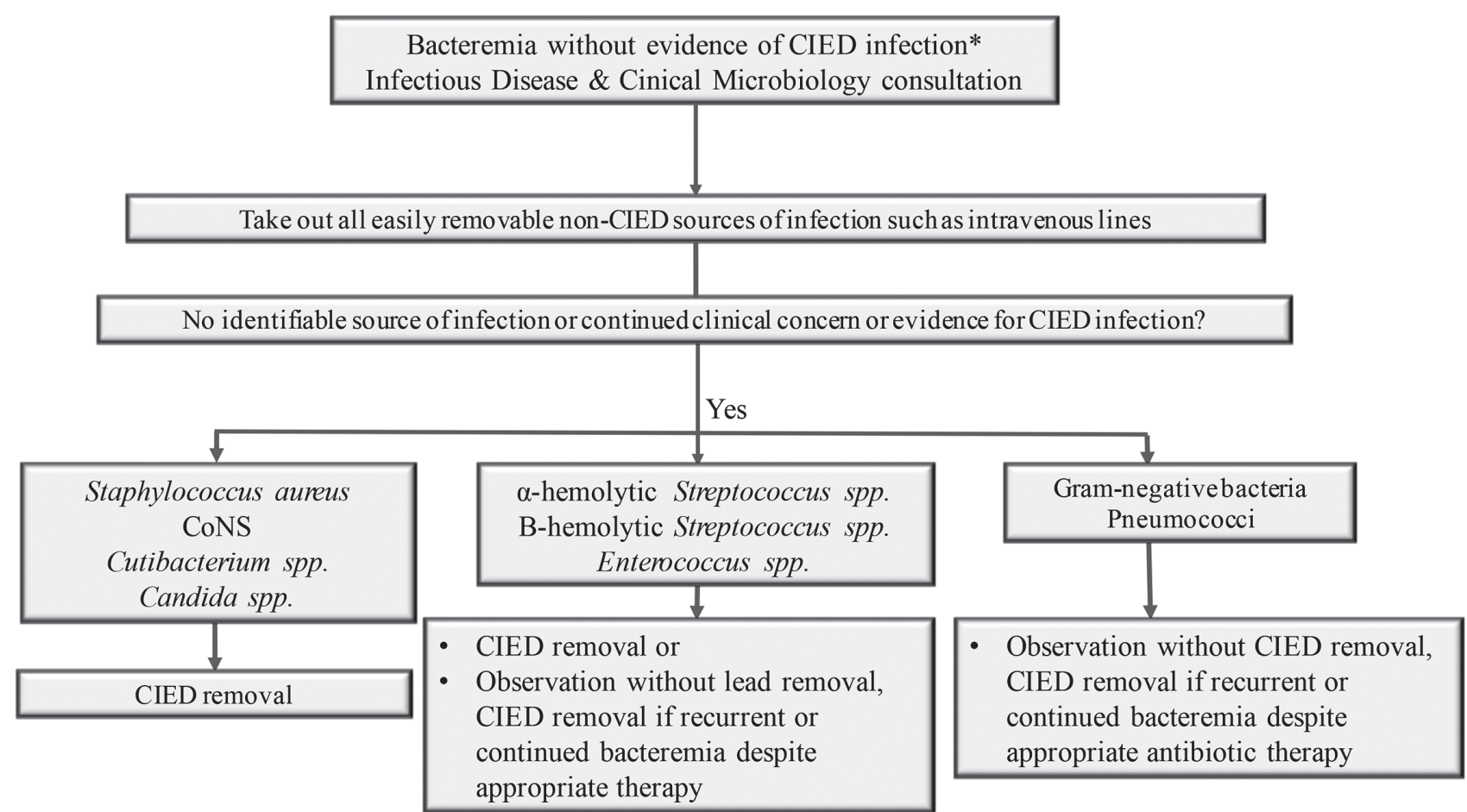

Figure 5. Management of bacteremia without evidence of CIED infection.

CIED: Cardiac implantable electronic devices; * Important to distinguish between blood stream infection and contamination in bacteremia involving skin flora. ${ }^{[70,415]}$

\section{Suspected CIED pocket infection}

Early superficial site infection: Erythema and/or
stitch abscess localized to superficial aspect of the
wound, within the first 30 days of device placement,
without fever or systemic toxicity

\begin{tabular}{|c|c|}
\hline $\begin{array}{c}\text { Course of oral antibiotics or } \\
\text { follow-up }\end{array}$ & Failed therapy \\
\end{tabular}

CIED pocket infection:Pocket discomfort, erythema, swelling, or purulent drainage, percutaneous exposure of the device generator and/or leads, with or without fever or systemic toxicity

Blood cultures, Transesophageal echocardiography (TEE)

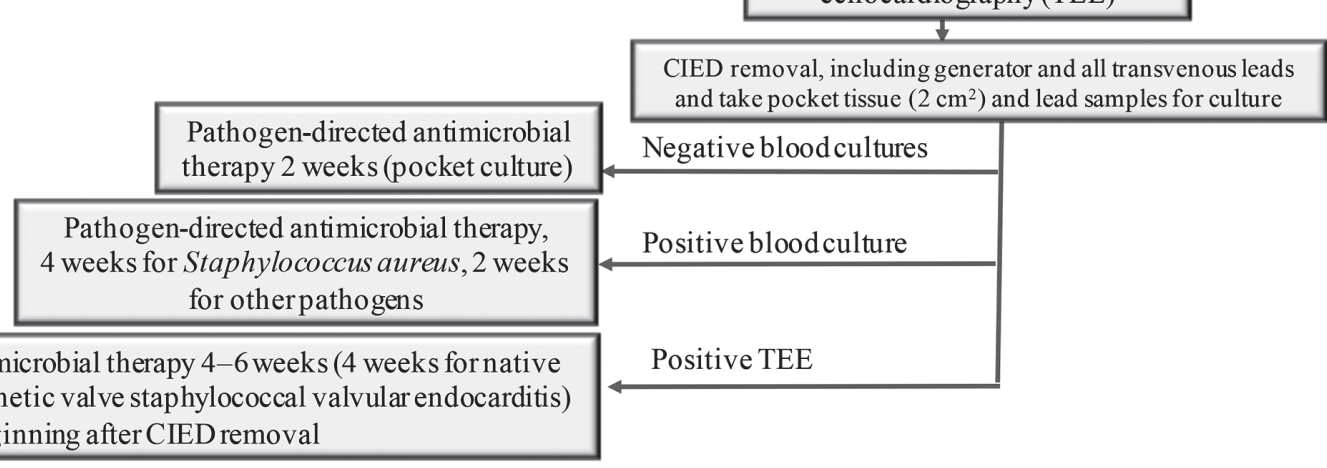

Figure 6. Management of suspected pocket infection. ${ }^{[70,413,415]}$ 
can easily visualize the tricuspid valve anatomy and its pathology in those patients. Infective endocarditis is mostly right-sided among IVDU, and $S$. aureus is the most common pathogen. The most prominent symptoms of IE among IVDU are fever and pulmonary symptoms mimicking respiratory tract infections. It is not possible to use short term (two-week duration) treatment modality in the treatment of right-sided endocarditis among IVDU due to MSSA in our country as anti-Staphylococcal penicillins are not currently available. Instead, these patients must be treated with cefazolin for a duration of four to six weeks. Oral combination therapy with ciprofloxacin and rifampin can be used for the treatment of uncomplicated right-side endocarditis in IVDUs caused by strains susceptible to both drugs; however, this approach should be reserved for special situations with the requirement of regular post-discharge follow-up patients in which conventional IV antibiotic therapy is not possible, or it is undesirable due to problems during their hospital stay. The increasing quinolone resistance among $S$. aureus strains may limit the use of this approach. ${ }^{[65,138,433-443]}$

What are the critical topics in the management of healthcare-associated IE?

At least a quarter of IE cases are healthcareassociated endocarditis at present. It is classified as nosocomial endocarditis, if it develops during the hospital stay or within six months after discharge. It is named as non-nosocomial healthcare-associated endocarditis, when the patient is exposed to health care interventions (i.e., hemodialysis, chemotherapy) outside the hospital within 30 days before the onset of signs or symptoms consistent with IE. Infective endocarditis has to be well-classified as community-acquired, nosocomial, or non-nosocomial healthcare-associated IE on admission, since the choices of empirical therapy are entirely different for healthcare-associated IE and community-acquired IE. ${ }^{[4,22,83,84,444-449]}$

\section{What are the critical topics in the management of IE in HIV-infected patients?}

Infective endocarditis among HIV-infected patients is common, particularly among IVDUs with HIV infection. The risk of developing IE is not increased in HIV-infected patients without IVDU. The IE incidence is higher among HIV-positive than HIVnegative IVDU. The development of IE is more natural compared to immunocompetent patients, and the mortality rate is higher in patients with lower $\mathrm{CD} 4^{+}$ $\mathrm{T}$ lymphocyte count. The morbidity and mortality rate of cardiovascular surgery is similar in IE of both HIV-positive and HIV-negative IVDU. The decision for valvular replacement has to be individualized in case of a repetitive risk of IE in patients due to the continuing habit of IVDU. ${ }^{[74,450-464]}$

\section{What are the critical topics of IE in elderly patients?}

Infective endocarditis has become more widespread in elderly patients. The clinical presentation is more silent in older patients with smaller vegetations and less embolic events. Healthcare-associated endocarditis is more common among older patients, as they have more prosthetic materials compared to younger patients. The causative pathogens are either Staphylococci acquired by healthcare or Streptococcus gallolyticus (Streptococcus bovis biotype I) or enterococci related to the intestinal or urinary source. Infective endocarditis in the elderly is more fatal than younger patients. The best explanation for the higher mortality rates among elderly is to have less likely surgery, when needed. Additionally, the antimicrobial treatment is unique in older patients with an increased risk of severe side effects and drug-drug interactions. A team involving a geriatric physician, a cardiologist, a cardiovascular surgeon, and an infectious disease specialist is essential to advocate for deciding diagnostic and therapeutic strategies in older patients with IE to accomplish these difficulties. . $^{[4,24,30,143,465-473]}$

What are the critical topics of IE observed in solid organ transplant (SOT) recipients?

The risk for IE is higher in SOT recipients than the general population, and IE is frequently overlooked. Gram-negative cocci and fungi can be the causative pathogens beside well-known classical pathogens such as taphylococci. If either the source of any bacteremia or fungemia is not known or a new embolic event occurs in SOT recipients, IE should be kept in mind in the differential diagnosis. ${ }^{[4,5,7,8,79,80,474-485]}$

What are the critical topics in the management of IE in patients with chronic renal failure and among patients receiving chronic hemodialysis?

Although all patients with chronic renal failure are at an increased risk of IE, the risk is highest among hemodialysis patients. The most important two factors to explain this situation are the increased prevalence of bacteremia and cardiac valvular calcifications occurring in hemodialysis patients. Nowadays, chronic hemodialysis patients comprise 10 to $20 \%$ of patients with IE, and IE occurs in 1 to $3 \%$ of patients with chronic hemodialysis. Left-sided endocarditis, with the involvement of the mitral valve, is common in patients with chronic renal failure. The most common 
pathogen is $S$. aureus. The risk of surgery and the risk of developing complications such as embolization is higher in this population. However, valvular surgery can be both feasible and beneficial in appropriately selected patients in whom guideline recommendations can be applied as well. There is no significant difference in the survival rates between the biological valve and the prosthetic valve replaced patients. The bioprosthetic valve is supposed to be more rational due to the increased tendency to hemorrhage and difficulty in long term anticoagulation among elderly with a short life expectancy. ${ }^{[77,78,486-498]}$

What are the critical topics in the management of the patient with endocarditis in the ICU?

The conditions predisposing to IE should be investigated in patients with ICU admission with acute heart failure, sepsis, and cranial or peripheral embolic events. Infective endocarditis should be in the differential diagnosis in those susceptible patients when a heart murmur is heard during the physical examination, and appropriate empirical treatment should be initiated promptly, if necessary. The echocardiographic examination should be performed to rule out the diagnosis of IE in ICU patients with persistent fever and continuing blood culture positivity, despite appropriate antimicrobial treatment. ${ }^{[65,499-524]}$

\section{What are the critical topics in the management of IE in pregnant women?}

The IE risk is not increased in pregnant women. However, if IE develops in a pregnant woman with a predisposing condition, the timing of both cardiovascular surgery and delivery should be decided by a multidisciplinary team composed of a cardiologist, a cardiovascular surgeon, an obstetrician, and a neonatologist. Cardiovascular surgery is not recommended for the first two trimesters. Cardiovascular surgery following an elective cesarean section is preferred after 28 gestation weeks. Emergent surgery must be planned, despite its higher fetal mortality in case of IE leading to acute heart failure. The principles of antimicrobial therapy for severe infections in pregnant women are also valid for pregnant women with IE. ${ }^{[104,525-530]}$

\section{IE?}

Should cancer screening be done in patients with

As the risk of colon cancer is higher in patients with Streptococcus gallolyticus (Streptococcus bovis biotype I) endocarditis, colonoscopy is recommended for those patients. Colonoscopy should be considered in patients with enterococcal endocarditis, even if the source of infection has not been identified. Cancer patients are in the higher risk group for the acquisition of healthcare-associated endocarditis, as they are more exposed to invasive procedures and as they need intensive healthcare. The probability of IE should be kept in mind and diagnostic work-up should be done, when cancer patients have a fever of unknown origin or a persistent fever. ${ }^{[531-536]}$

\section{ANTITHROMBOTIC THERAPY IN IE}

Which antithrombotic agents in which indications should be used in patients with IE and how?

All antithrombotic therapy should be ceased in case of severe intracranial hemorrhage in patients with IE who already on oral anticoagulants for their prosthetic valves. However, it is recommended to initiate parenteral anticoagulation as soon as possible for these patients. Ongoing oral anticoagulants must be shifted to the parenteral route in case of an ischemic neurological event without hemorrhage in patients with IE. It is essential to make all decisions following multidisciplinary discussion. ${ }^{[181,537,538]}$

\section{PREVENTION OF IE}

How and in what situations should antimicrobial prophylaxis be done in patients with IE?

Antimicrobial prophylaxis is only being recommended before invasive dental procedures in patients at the highest risk for the acquisition of IE (previous IE, presence of prosthetic heart valve or ring annuloplasty, cyanotic congenital heart disease and cardiac allograft valvulopathy). A single dose of $2 \mathrm{~g}$ amoxicillin or $600 \mathrm{mg}$ clindamycin given orally one hour before the procedure is recommended as prophylaxis.

Patients with IE should be examined by the dentist to be sure of the probable dental source of infection, and if a probable source is existing, it must eliminated. An additional dose of prophylactic antimicrobial agent, preferably selecting a different class of antibiotic to cover whole probable pathogens should be given one hour before the procedure to those patients who have already been receiving appropriate antimicrobials for their IE. . $3,17,25,58,61,65,66,269,376,539-567]^{2}$

What is recommended to high-risk patients for IE about their oral and dental hygiene?

High-risk patients to develop IE should seek professional dental care twice a year, whereas intermediate-risk patients should have it annually. ${ }^{[65]}$ 


\section{What are the other measures in the prevention of IE?}

Central venous catheters should not be placed to patients with the risk of IE, unless required. If catheterization is necessary, the catheter should be, then, inserted using an aseptic technique and maximal sterile barrier precautions, including the use of a cap, mask, sterile gown, sterile gloves, and a sterile full-body drape. Anti-staphylococcal therapy for five and seven days is recommended for patients with a predisposing condition for the acquisition of IE, if $S$. aureus is isolated from their removed intra-venous catheter's tip culture. There has been no vaccine available in clinical use to prevent IE recently. The procedures breaching the skin integrity like tattoos and body piercing should be avoided. Nose picking should be avoided to prevent the nasal carriage of $S$. aureus and transient bacteremia, if $S$. aureus nasal carriage is already present.

The Stöckert 3T heater-cooler system devices manufactured in the years between 2006 and 2014 are known to be contaminated with $\mathrm{M}$. chimera and should not be used at the cardiovascular surgery centers, if particularly either prosthetic valve or vascular graft will be replaced. ${ }^{[65,102,121,568-585]}$

\section{Infective Endocarditis and Other Cardiovascular Infections Study Group}

Özlem Azap, Seniha Başaran, Yasemin Çağ, Atahan Çağatay, Güle Çınar, Sibel Doğan-Kaya, Lokman Hızmalı, Mehmet Emirhan Işık, Nirgül Kılıçaslan, Şirin Menekşe, Meliha Meriç-Koç, Serpil Öztürk, Ayfer Şensoy, Yasemin Tezer-Tekçe, Elif Tükenmez-Tigen, Yeşim Uygun-Kızmaz, Mutlu Şeyda Velioğlu-Öcalmaz, Ayşegül Yeşilkaya, Emel Yılmaz, Neziha Yilmaz, Fatma Yilmaz-Karadağ

\section{Declaration of conflicting interests}

The authors declared no conflicts of interest with respect to the authorship and/or publication of this article.

\section{Funding}

The authors received no financial support for the research and/or authorship of this article.

\section{REFERENCES}

1. Bin Abdulhak AA, Baddour LM, Erwin PJ, Hoen B, Chu $\mathrm{VH}$, Mensah GA, et al. Global and regional burden of infective endocarditis, 1990-2010: a systematic review of the literature. Glob Heart 2014;9:131-43.

2. Cahill TJ, Prendergast BD. Infective endocarditis. Lancet 2016;387:882-93.

3. Baddour LM, Wilson WR, Bayer AS, Fowler VG Jr, Tleyjeh IM, Rybak MJ, et al. Infective Endocarditis in Adults: Diagnosis, Antimicrobial Therapy, and Management of Complications: A Scientific Statement for Healthcare
Professionals From the American Heart Association. Circulation 2015;132:1435-86.

4. Şimşek-Yavuz S, Şensoy A, Kaşıkçıŏlu H, Çeken S, Deniz D, Yavuz A, et al. Infective endocarditis in Turkey: aetiology, clinical features, and analysis of risk factors for mortality in 325 cases. Int J Infect Dis 2015;30:106-14.

5. Hoen B, Duval X. Clinical practice. Infective endocarditis. N Engl J Med 2013;368:1425-33.

6. Seckeler MD, Hoke TR. The worldwide epidemiology of acute rheumatic fever and rheumatic heart disease. Clin Epidemiol 2011;3:67-84.

7. Tibazarwa KB, Volmink JA, Mayosi BM. Incidence of acute rheumatic fever in the world: a systematic review of population-based studies. Heart 2008;94:1534-40.

8. Allegranzi B, Bagheri Nejad S, Combescure C, Graafmans W, Attar H, Donaldson L, et al. Burden of endemic health-care-associated infection in developing countries: systematic review and meta-analysis. Lancet 2011;377:228-41.

9. Köse MR. Sağlık İstatistikleri Yıllı̆̆g 2015. Ankara: Sağlık Bakanlığı Sağlık Araştırmaları Genel Müdürlüğü; 2016.

10. Türkiye Halk Sağlı̆̆1 Kurumu. Faaliyet Raporu 2015. Ankara: Sağlık Bakanlığı; 2016.

11. Gümüşlü F, Özkara Ş, Özkan S, Baykal F, Güllü Ü. Türkiye'de Verem Savaşı, 2007 Raporu. Ankara: Sağlık Bakanlığı Verem Savaşı Dairesi Başkanlığı; 2007.

12. Kandemir Ö. Bruselloz. Turkiye Klinikleri J Inf DisSpecial Topics 2015;8:1-9.

13. Kaura A, Dworakowska D, Dworakowski R. Infective endocarditis - Cinderella in cardiology. Kardiol Pol 2017;75:965-74

14. Naderi HR, Sheybani F, Erfani SS. Errors in diagnosis of infective endocarditis. Epidemiol Infect 2018;146:394-400.

15. Başaran S, Şimşek-Yavuz S, Alp E, Keskin Ç, Çağatay A, Öncül O ve ark. İnfektif endokarditin tanınamaması, tanısının gecikmesi ve sonuçları. In: Tekin S, editör. XX. Türk Klinik Mikrobiyoloji ve İnfeksiyon Hastalıkları Kongresi (13-16 Mart 2019, Antalya) Kitabı. İstanbul: Türk Klinik Mikrobiyoloji ve İnfeksiyon Hastalıkları Derneği; 2019. s. 266-7.

16. Aydın M, Azap Ö, Şimşek-Yavuz S. İnfektif endokardit tanı ve tedavi olanaklarının belirlenmesi: neyi, ne kadar yapabiliyoruz. In: Tekin S, editör. Klimik 2016: 30. Y1l Kurultayı (9-12 Mart 2016, Antalya) Özet Kitabı. İstanbul: Türk Klinik Mikrobiyoloji ve İnfeksiyon Hastalıkları Derneği; 2016. s. 450-1.

17. Yılmaz-Karadağ F, Şimşek-Yavuz S, Karadeniz A, Aydın Ö, Ergen P, Tükenmez-Tigen E ve ark. Diş hekimlerinin infektif endokardit profilaksisi hakkinda bilgi düzeylerinin değerlendirilmesi: ön çalışma verileri. In: Tekin S, editör. Klimik 2016: 30. Y1l Kurultay1 (9-12 Mart 2016, Antalya) Özet Kitabı. İstanbul: Türk Klinik Mikrobiyoloji ve İnfeksiyon Hastalıkları Derneği; 2016. s. 292-3.

18. Tissot-Dupont H, Casalta JP, Gouriet F, Hubert S, Salaun E, Habib G, et al. International experts' practice in the antibiotic therapy of infective endocarditis is not following the guidelines. Clin Microbiol Infect 2017;23:736-9.

19. Cresti A, Chiavarelli M, Scalese M, Nencioni C, Valentini S, Guerrini F, et al. Epidemiological and mortality trends 
in infective endocarditis, a 17-year population-based prospective study. Cardiovasc Diagn Ther 2017;7:27-35.

20. Slipczuk L, Codolosa JN, Davila CD, Romero-Corral A, Yun J, Pressman GS, et al. Infective endocarditis epidemiology over five decades: a systematic review. PLoS One 2013;8:e82665.

21. Holland TL, Baddour LM, Bayer AS, Hoen B, Miro JM, Fowler VG Jr. Infective endocarditis. Nat Rev Dis Primers 2016;2:16059.

22. Toyoda N, Chikwe J, Itagaki S, Gelijns AC, Adams DH, Egorova NN. Trends in Infective Endocarditis in California and New York State, 1998-2013. JAMA 2017;317:1652-60.

23. Murdoch DR, Corey GR, Hoen B, Miró JM, Fowler VG Jr, Bayer AS, et al. Clinical presentation, etiology, and outcome of infective endocarditis in the 21st century: the International Collaboration on Endocarditis-Prospective Cohort Study. Arch Intern Med 2009;169:463-73.

24. Selton-Suty C, Célard M, Le Moing V, Doco-Lecompte T, Chirouze C, Iung B, et al. Preeminence of Staphylococcus aureus in infective endocarditis: a 1-year population-based survey. Clin Infect Dis 2012;54:1230-9.

25. Duval X, Delahaye F, Alla F, Tattevin P, Obadia JF, Le Moing V, et al. Temporal trends in infective endocarditis in the context of prophylaxis guideline modifications: three successive population-based surveys. J Am Coll Cardiol 2012;59:1968-76.

26. Hoen B, Alla F, Selton-Suty C, Béguinot I, Bouvet A, Briançon $\mathrm{S}$, et al. Changing profile of infective endocarditis: results of a 1-year survey in France. JAMA 2002;288:75-81.

27. Cahill TJ, Baddour LM, Habib G, Hoen B, Salaun E, Pettersson GB, et al. Challenges in Infective Endocarditis. J Am Coll Cardiol 2017;69:325-44.

28. Fatima S, Dao B, Jameel A, Sharma K, Strogatz D, Scribani M, et al. Epidemiology of Infective Endocarditis in Rural Upstate New York, 2011 - 2016. J Clin Med Res 2017;9:754-8.

29. Cetinkaya Y, Akova M, Akalin HE, Aşçioğlu S, Hayran M, Uzuns O, et al. A retrospective review of 228 episodes of infective endocarditis where rheumatic valvular disease is still common. Int J Antimicrob Agents 2001;18:1-7.

30. Leblebicioglu H, Yilmaz H, Tasova Y, Alp E, Saba R, Caylan R, et al. Characteristics and analysis of risk factors for mortality in infective endocarditis. Eur J Epidemiol 2006;21:25-31.

31. Elbey MA, Akdağ S, Kalkan ME, Kaya MG, Sayın MR, Karapinar H, et al. A multicenter study on experience of 13 tertiary hospitals in Turkey in patients with infective endocarditis. Anadolu Kardiyol Derg 2013;13:523-7.

32. Cancan Gursul N, Vardar I, Demirdal T, Gursul E, Ural S, Yesil M. Clinical and microbiological findings of infective endocarditis. J Infect Dev Ctries 2016;10:478-87.

33. Zencir C, Akpek M, Senol S, Selvi M, Onay S, Cetin M, et al. Association between hematologic parameters and in-hospital mortality in patients with infective endocarditis. Kaohsiung J Med Sci 2015;31:632-8.

34. Tuğcu A, Yildirimtürk O, Baytaroğlu C, Kurtoğlu H, Köse O, Sener M, et al. Clinical spectrum, presentation, and risk factors for mortality in infective endocarditis: a review of 68 cases at a tertiary care center in Turkey. Turk Kardiyol Dern Ars 2009;37:9-18.

35. Sucu M, Davutoğlu V, Ozer O, Aksoy M. Epidemiological, clinical and microbiological profile of infective endocarditis in a tertiary hospital in the South-East Anatolia Region. Turk Kardiyol Dern Ars 2010;38:107-11.

36. Heper G, Yorukoglu Y. Clinical, bacteriologic and echocardiographic evaluation of infective endocarditis in Ankara, Turkey. Angiology 2002;53:191-7.

37. Agca FV, Demircan N, Peker T, Ari H, Karaagac K, Ozluk OA, et al. Infective endocarditis: a tertiary referral centre experience from Turkey. Int J Clin Exp Med 2015;8:13962-8.

38. Işıkgöz-Taşbakan M, Guliyeva G, Kayıkçığlu M, Yamazhan T, Özcem S, Pullukçu H ve ark. Enfektif endokardit: 100 hastanin değerlendirilmesi. In: 32. Ankem Akılcı Antibiyotik Kullanımı Kongresi (10-14 Mayıs 2017, Antalya) Kitabı. İstanbul: Antibiyotik ve Kemoterapi Derneği; 2017. s. 104.

39. Erbay AR, Erbay A, Canga A, Keskin G, Sen N, Atak R, et al. Risk factors for in-hospital mortality in infective endocarditis: five years' experience at a tertiary care hospital in Turkey. J Heart Valve Dis 2010;19:216-24.

40. Akıl MA, Acet H, Elbey MA, Aydın M, Bilik Z, Yıldız A, et al. Prognostic factors and in-hospital outcome of native valve endocarditis in Turkey. A multicenter study. Acta Medica Mediterranea 2014;30:1035-9.

41. Adademir T, Tuncer EY, Tas S, Donmez AA, Polat EB, Tuncer A. Surgical treatment of aortic valve endocarditis: a 26-year experience. Rev Bras Cir Cardiovasc 2014;29:16-24.

42. Cay S, Gürel OM, Korkmaz S. Clinical and epidemiological characteristics of infective endocarditis. Turk Kardiyol Dern Ars 2009;37:182-6.

43. Turak O, Canpolat U, Ozcan F, Yayla C, Mendi MA, Oksüz $\mathrm{F}$, et al. D-dimer level predicts in-hospital mortality in patients with infective endocarditis: a prospective singlecentre study. Thromb Res 2014;134:587-92.

44. Ozveren O, Oztürk MA, Sengül C, Bakal RB, Akgün T, Izgi $\mathrm{C}$, et al. Infective endocarditis and complications; a single center experience. Turk Kardiyol Dern Ars. 2014;42:629-34.

45. Kocabaş U, Kaya E, Özerkan-Çakan F. Microbiological profile, echocardiographic characteristics and early results of infective endocarditis: a review of 194 cases at a tertiary care center in Turkey. J Am Coll Cardiol 2013;62(18; Suppl. 2):81.

46. Kucukates E, Gultekin N, Bagdatli Y. Cases of active infective endocarditis in a university hospital during a 10-year period. J Pak Med Assoc 2013;63:1163-7.

47. Kaya Z, Yıldız A, Biçer-Yeşilay A, Kocaaslan A, Aydın MS, Sezen Y, et al. Merkezimizde takip edilen her üç enfektif endokardit olgusundan birisi Brusella endokarditidir. Gaziantep Tip Derg 2013;19:103-7.

48. Çaylan R, Aydın K, Kaygusuz S, Köksal İ, Örem C. Otuziki infektif endokardit atağının değerlendirilmesi. Flora 2001;6:267-73.

49. İnanç MT, Kaya MG, Gündüz Kaya E, Doğan A, Ardıç İ, Doğru O. İnfektif endokardit: retrospektif olarak 27 
hastanın değerlendirilmesi. Tip Araştırmaları Derg 2007;5:91-9.

50. Şimşek-Yavuz S, Berzeg-Deniz D, Tükenmez-Tigen E, et al. In: Tekin S, Şimşek F, editörler. KLİMİK İEÇG Türkiye infektif endokardit kohortu: 2015-2016 verileri. XVIII. Türk Klinik Mikrobiyoloji ve İnfeksiyon Hastalıkları Kongresi (22-26 Mart 2017, Antalya) Özet Kitabı. İstanbul: Türk Klinik Mikrobiyoloji ve İnfeksiyon Has-talıkları Derneği; 2017. s. 133.

51. Frontera JA, Gradon JD. Right-side endocarditis in injection drug users: review of proposed mechanisms of pathogenesis. Clin Infect Dis 2000;30:374-9.

52. Orün UA, Ceylan O, Bilici M, Karademir S, Ocal B, Senocak F, et al. Acute rheumatic fever in the Central Anatolia Region of Turkey: a 30-year experience in a single center. Eur J Pediatr 2012;171:361-8.

53. Onat A, Keleş İ, Çetinkaya A, Başar Ö, Yildirim B, Erer B, et al. Prevalence of Coronary Mortality and Morbidity in the Turkish Adult Risk Factor Study: 10-year Follow-up Suggests Coronary "Epidemic". Turk Kardiyol Dern Ars 2001;29:8-19.

54. Onat A, Şurdumavcı G, Şenocak M, Örnek E, Gözükara E, Karaaslan Y, et al. Survey on Prevalence of Cardiac Disease and its Risk Factors in Adults in Turkey: 3. Prevalence of Heart Diseases. Turk Kardiyol Dern Ars 1991;19:26-33.

55. Demirbağ R, Sade LE, Aydın M, Bozkurt A, Acartürk E. The Turkish registry of heart valve disease. Turk Kardiyol Dern Ars 2013;41:1-10.

56. Watkins DA, Johnson CO, Colquhoun SM, Karthikeyan G, Beaton A, Bukhman G, et al. Global, Regional, and National Burden of Rheumatic Heart Disease, 1990-2015. N Engl J Med 2017;377:713-22.

57. Marijon E, Mirabel M, Celermajer DS, Jouven X. Rheumatic heart disease. Lancet 2012;379:953-64.

58. Baskerville CA, Hanrahan BB, Burke AJ, Holwell AJ, Rémond MG, Maguire GP. Infective endocarditis and rheumatic heart disease in the north of Australia. Heart Lung Circ 2012;21:36-41.

59. Katan O, Michelena HI, Avierinos JF, Mahoney DW, DeSimone DC, Baddour LM, et al. Incidence and predictors of infective endocarditis in mitral valve prolapse: A population-based study. Mayo Clin Proc 2016;91:336-42.

60. Zegri-Reiriz I, de Alarcón A, Muñoz P, Martínez Sellés M, González-Ramallo V, Miro JM, et al. Infective endocarditis in patients with bicuspid aortic valve or mitral valve prolapse. J Am Coll Cardiol 2018;71:2731-40.

61. Baumgartner H. Infective endocarditis in adults with congenital heart disease: is it time to change our approach to prophylaxis based on new insights into risk prediction? Eur Heart J 2011;32:1835-7.

62. Mylotte D, Rushani D, Therrien J, Guo L, Liu A, Guo $\mathrm{K}$, et al. Incidence, Predictors, and Mortality of Infective Endocarditis in Adults With Congenital Heart Disease Without Prosthetic Valves. Am J Cardiol 2017;120:2278-83.

63. Li Y, Wei X, Zhao Z, Liao Y, He J, Xiong T, et al. Prevalence and complications of bicuspid aortic valve in chinese according to echocardiographic database. Am J Cardiol 2017;120:287-91.
64. Regueiro A, Linke A, Latib A, Ihlemann N, Urena M, Walther T, et al. Association between transcatheter aortic valve replacement and subsequent infective endocarditis and in-hospital death. JAMA 2016;316:1083-92.

65. Habib G, Lancellotti P, Antunes MJ, Bongiorni MG, Casalta JP, Del Zotti F, et al. 2015 ESC Guidelines for the management of infective endocarditis: The Task Force for the Management of Infective Endocarditis of the European Society of Cardiology (ESC). Endorsed by: European Association for Cardio-Thoracic Surgery (EACTS), the European Association of Nuclear Medicine (EANM). Eur Heart J 2015;36:3075-128.

66. SEC Working Group for the ESC 2015 Guidelines on the Management of Infective Endocarditis; Expert Reviewers for the ESC 2015 Guidelines on the Management of Infective Endocarditis; SEC Guidelines Committee. Comments on the ESC 2015 Guidelines for the Management of Infective Endocarditis. Rev Esp Cardiol (Engl Ed) 2016;69:7-10.

67. Amat-Santos IJ, Ribeiro HB, Urena M, Allende R, Houde $\mathrm{C}$, Bédard E, et al. Prosthetic valve endocarditis after transcatheter valve replacement: a systematic review. JACC Cardiovasc Interv 2015;8:334-46.

68. Sandoe JA, Barlow G, Chambers JB, Gammage M, Guleri A, Howard P, et al. Guidelines for the diagnosis, prevention and management of implantable cardiac electronic device infection. Report of a joint Working Party project on behalf of the British Society for Antimicrobial Chemotherapy (BSAC, host organization), British Heart Rhythm Society (BHRS), British Cardiovascular Society (BCS), British Heart Valve Society (BHVS) and British Society for Echocardiography (BSE). J Antimicrob Chemother 2015;70:325-59.

69. Johansen JB, Jørgensen OD, Møller M, Arnsbo P, Mortensen PT, Nielsen JC. Infection after pacemaker implantation: infection rates and risk factors associated with infection in a population-based cohort study of 46299 consecutive patients. Eur Heart J 2011;32:991-8.

70. Baddour LM, Epstein AE, Erickson CC, Knight BP, Levison ME, Lockhart PB, et al. Update on cardiovascular implantable electronic device infections and their management: a scientific statement from the American Heart Association. Circulation 2010;121:458-77.

71. Aydin M, Yildiz A, Kaya Z, Kaya Z, Basarir AO, Cakmak N, et al. Clinical Characteristics and Outcome of Cardiovascular Implantable Electronic Device Infections in Turkey. Clin Appl Thromb Hemost 2016;22:459-64.

72. Hannan MM, Husain S, Mattner F, Danziger-Isakov L, Drew RJ, Corey GR, et al. Working formulation for the standardization of definitions of infections in patients using ventricular assist devices. J Heart Lung Transplant 2011;30:375-84.

73. Kusne S, Staley L, Arabia F. Prevention and Infection Management in Mechanical Circulatory Support Device Recipients. Clin Infect Dis 2017;64:222-8.

74. Wilson LE, Thomas DL, Astemborski J, Freedman TL, Vlahov D. Prospective study of infective endocarditis among injection drug users. J Infect Dis 2002;185:1761-6. 
75. Keeshin SW, Feinberg J. Endocarditis as a Marker for New Epidemics of Injection Drug Use. Am J Med Sci 2016;352:609-14.

76. Wurcel AG, Anderson JE, Chui KK, Skinner S, Knox TA, Snydman DR, et al. Increasing Infectious Endocarditis Admissions Among Young People Who Inject Drugs. Open Forum Infect Dis 2016;3:ofw157.

77. Díaz-García HR, Contreras-de la Torre NA, AlemánVillalobos A, et al. Infective endocarditis in end-stage renal disease patients in developing countries: what is the real problem? In: Firstenberg MS, editor. Contemporary Challenges in Endocarditis. Lon-don: IntechOpen; 2016. p. 121-42.

78. Chaudry MS, Carlson N, Gislason GH, Kamper AL, Rix M, Fowler VG Jr, et al. Risk of infective endocarditis in patients with end stage renal disease. Clin J Am Soc Nephrol 2017;12:1814-22.

79. Ruttmann E, Bonatti H, Legit C, Ulmer H, Stelzmueller I, Antretter $\mathrm{H}$, et al. Severe endocarditis in transplant recipients--an epidemiologic study. Transpl Int 2005;18:690-6.

80. Paterson DL, Dominguez EA, Chang FY, Snydman DR, Singh N. Infective endocarditis in solid organ transplant recipients. Clin Infect Dis 1998;26:689-94.

81. Olmos C, Vilacosta I, Fernández C, Sarriá C, López J, Del Trigo M, et al. Comparison of clinical features of left-sided infective endocarditis involving previously normal versus previously abnormal valves. Am J Cardiol 2014;114:278-83.

82. Fowler VG Jr, Miro JM, Hoen B, Cabell CH, Abrutyn E, Rubinstein E, et al. Staphylococcus aureus endocarditis: a consequence of medical progress. JAMA 2005;293:3012-21.

83. Lomas JM, Martínez-Marcos FJ, Plata A, Ivanova R, Gálvez J, Ruiz J, et al. Healthcare-associated infective endocarditis: an undesirable effect of healthcare universalization. Clin Microbiol Infect 2010;16:1683-90.

84. Fernández-Hidalgo N, Almirante B, Tornos P, Pigrau C, Sambola A, Igual A, et al. Contemporary epidemiology and prognosis of health care-associated infective endocarditis. Clin Infect Dis 2008;47:1287-97.

85. Ambrosioni J, Hernandez-Meneses M, Téllez A, Pericàs J, Falces C, Tolosana JM, et al. The changing epidemiology of infective endocarditis in the twenty-first century. Curr Infect Dis Rep 2017;19:21.

86. Fowler VG, Scheld WM, Bayer AS. Endocarditis and intravascular infections. In: Bennett JE, Dolin R, Blaser MJ, editors. Mandell, Douglas, and Bennett's Principles and Practice of Infectious Diseases. 8th ed. Philadelphia: Elsevier Saunders; 2015. p. 990-1028.

87. Sabe MA, Shrestha NK, Gordon S, Menon V. Staphylococcus lugdunensis: a rare but destructive cause of coagulasenegative staphylococcus infective endocarditis. Eur Heart J Acute Cardiovasc Care 2014;3:275-80.

88. Şimşek-Yavuz S, Başaran S, Aliyev V, Midilli K, Çağatay A, Özsüt H, et al. Diphtheroids in blood cultures could be streptococcus mutans: A case of infective endocarditis diagnosed after 16 months. Klimik Dergisi 2015;28:122-5.

89. Şimşek Yavuz S, Eren M, Yavuz A, Biçer Y, Koçak F, Bilgen F, et al. İnfektif endokardit: 58 olgunun değerlendirilmesi.
Klimik Derg 2003;16:55-62.

90. Schlegel L, Grimont F, Ageron E, Grimont PA, Bouvet A. Reappraisal of the taxonomy of the Streptococcus bovis/Streptococcus equinus complex and related species: description of Streptococcus gallolyticus subsp. gallolyticus subsp. nov., S. gallolyticus subsp. macedonicus subsp. nov. and S. gallolyticus subsp. pasteurianus subsp. nov. Int J Syst Evol Microbiol 2003;53:631-45.

91. Boleij A, Muytjens CM, Bukhari SI, Cayet N, Glaser P, Hermans PW, et al. Novel clues on the specific association of Streptococcus gallolyticus subsp gallolyticus with colorectal cancer. J Infect Dis 2011;203:1101-9.

92. Boleij A, van Gelder MM, Swinkels DW, Tjalsma H. Clinical Importance of Streptococcus gallolyticus infection among colorectal cancer patients: systematic review and meta-analysis. Clin Infect Dis 2011;53:870-8.

93. Corredoira-Sánchez J, García-Garrote F, Rabuñal R, López-Roses L, García-País MJ, Castro E, et al. Association between bacteremia due to Streptococcus gallolyticus subsp. gallolyticus (Streptococcus bovis I) and colorectal neoplasia: a case-control study. Clin Infect Dis 2012;55:491-6.

94. Kumar R, Herold JL, Taylor J, Xu J, Xu Y. Variations among Streptococcus gallolyticus subsp. gallolyticus strains in connection with colorectal cancer. Sci Rep 2018;8:1514.

95. Kumar R, Herold JL, Schady D, Davis J, Kopetz S, Martinez-Moczygemba M, et al. Streptococcus gallolyticus subsp. gallolyticus promotes colorectal tumor development. PLoS Pathog 2017;13:e1006440.

96. Dahl A, Lauridsen TK, Arpi M, Sørensen LL, Østergaard C, Sogaard P, et al. Risk factors of endocarditis in patients with enterococcus faecalis bacteremia: External validation of the NOVA score. Clin Infect Dis 2016;63:771-5.

97. Bouza E, Kestler M, Beca T, Mariscal G, RodríguezCréixems M, Bermejo J, et al. The NOVA score: a proposal to reduce the need for transesophageal echocardiography in patients with enterococcal bacteremia. Clin Infect Dis 2015;60:528-35.

98. Berge A, Krantz A, Östlund H, Nauclér P, Rasmussen M. The DENOVA score efficiently identifies patients with monomicrobial Enterococcus faecalis bacteremia where echocardiography is not necessary. Infection 2019;47:45-50.

99. Chirouze C, Athan E, Alla F, Chu VH, Ralph Corey G, Selton-Suty C, et al. Enterococcal endocarditis in the beginning of the 21st century: analysis from the International Collaboration on Endocarditis-Prospective Cohort Study. Clin Microbiol Infect 2013;19:1140-7.

100. Komiyama EY, Lepesqueur LS, Yassuda CG, Samaranayake LP, Parahitiyawa NB, Balducci I, et al. Enterococcus species in the oral cavity: Prevalence, virulence factors and antimicrobial susceptibility. PLoS One 2016;11:e0163001.

101. Pericàs JM, Corredoira J, Moreno A, García-País MJ, Falces C, Rabuñal R, et al. Relationship between enterococcus faecalis infective endocarditis and colorectal neoplasm: Preliminary results from a cohort of 154 patients. Rev Esp Cardiol (Engl Ed) 2017;70:451-8. 
102. Şimşek-Yavuz S. İnfektif endokardit: Güncel bilgiler. Klimik Derg 2015;28:46-67.

103. Koruk ST, Erdem H, Koruk I, Erbay A, Tezer-Tekce Y, Erbay AR, et al. Management of Brucella endocarditis: results of the Gulhane study. Int J Antimicrob Agents 2012;40:145-50.

104. Gilbert DN, Chambers HF, Eliopoulos GM, Saag MS, Pavia AT, editors. The Sanford Guide to Antimicrobial Therapy 2019. 49th ed. Sperryville, VA: Antimicrobial Therapy, Inc.; 2019.

105. Chambers ST, Murdoch D, Morris A, Holland D, Pappas $\mathrm{P}$, Almela $\mathrm{M}$, et al. HACEK infective endocarditis: characteristics and outcomes from a large, multi-national cohort. PLoS One 2013;8:e63181.

106. Lützen L, Olesen B, Voldstedlund M, Christensen JJ, Moser $\mathrm{C}$, Knudsen JD, et al. Incidence of HACEK bacteraemia in Denmark: A 6-year population-based study. Int J Infect Dis 2018;68:83-7.

107. Revest M, Egmann G, Cattoir V, Tattevin P. HACEK endocarditis: state-of-the-art. Expert Rev Anti Infect Ther 2016;14:523-30.

108. Morpeth S, Murdoch D, Cabell CH, Karchmer AW, Pappas P, Levine D, et al. Non-HACEK gram-negative bacillus endocarditis. Ann Intern Med 2007;147:829-35.

109. Falcone M, Tiseo G, Durante-Mangoni E, Ravasio V, Barbaro F, Ursi MP, et al. Risk Factors and Outcomes of Endocarditis Due to Non-HACEK Gram-Negative Bacilli: Data from the Prospective Multicenter Italian Endocarditis Study Cohort. Antimicrob Agents Chemother 2018;62:pii:e02208-17.

110. San Román JA, Vilacosta I, López J, Sarriá C. Critical questions about left-sided infective endocarditis. J Am Coll Cardiol 2015;66:1068-76.

111. Fournier PE, Thuny F, Richet H, Lepidi H, Casalta JP, Arzouni JP, et al. Comprehensive diagnostic strategy for blood culture-negative endocarditis: a prospective study of 819 new cases. Clin Infect Dis 2010;51:131-40.

112. Houpikian P, Raoult D. Blood culture-negative endocarditis in a reference center: etiologic diagnosis of 348 cases. Medicine (Baltimore) 2005;84:162-73.

113. Geissdörfer W, Moos V, Moter A, Loddenkemper C, Jansen A, Tandler R, et al. High frequency of tropheryma whipplei in culture-negative endocarditis. J Clin Microbiol 2012;50:216-22.

114. Million M, Thuny F, Richet H, Raoult D. Long-term outcome of Q fever endocarditis: a 26-year personal survey. Lancet Infect Dis 2010;10:527-35.

115. Şimşek Yavuz S, Özbek E, Başaran S, Çelebi B, Yılmaz $\mathrm{E}$, Başaran $\mathrm{M}$, et al. The first case of chronic Q fever endocarditis and aortitis from Turkey: A 5-year infection before diagnosis with drain in sternum. Anatol J Cardiol 2016;16:814-6.

116. Şimşek-Yavuz S, Başaran S, Yılmaz E, Keskin Ç, Alp $\mathrm{E}, \mathrm{K}$ ılıç $\mathrm{S}$ ve ark. İnfektif endokardit tanısına serolojik incelemelerin ve PET/BT'nin katkıları. In: Tekin S, editör. XX. Türk Klinik Mikrobiyoloji ve İnfeksiyon Hastalıkları Kongresi (13-16 Mart 2019, Antalya) Kitabı. İstanbul: Türk Klinik Mikrobiyoloji ve İnfeksiyon Hastalıkları Derneği; 2019. s. 224-5.
117. Özdemir S. Nadir Rastlanan Enfektif Endokardit Etkenlerinin Araştırılması: HACEK Grubu Mikroorganizmalar, Chlamydophila pneumoniae, Coxiella Türleri ve Bartonella Türleri [Doktora Tezi]. İstanbul: İstanbul Üniversitesi Sağlık Bilimleri Enstitüsü; 2012.

118. Karaman İN, Azizy A, Yılmaz Ş, Tükenmez-Tigen E, Odabaşı Z, Söyletir G ve ark. Bir kültür negatif doğal kapak endokarditi etkeni olarak Bartonella quintana. In: Tekin S, editör. XX. Türk Klinik Mikrobiyoloji ve İnfeksiyon Hastalıkları Kongresi (13-16 Mart 2019, Antalya) Kitabı. İstanbul: Türk Klinik Mikrobiyoloji ve İnfeksiyon Hastalıkları Derneği; 2019. s. 321-2.

119. Liesman RM, Pritt BS, Maleszewski JJ, Patel R. Laboratory diagnosis of infective endocarditis. J Clin Microbiol 2017;55:2599-608.

120. Brusch JL. Legionnaire's disease: Cardiac manifestations. Infect Dis Clin North Am 2017;31:69-80.

121. Marra AR, Diekema DJ, Edmond MB. Mycobacterium chimaera Infections Associated With Contaminated Heater-Cooler Devices for Cardiac Surgery: Outbreak Management. Clin Infect Dis 2017;65:669-74.

122. Şimşek-Yavuz S. Açık kalp cerrahisi uygulanmış hastalarda kontamine isıtıc1-soğutucu cihazlarla ilişkili mycobacterium chimaera infeksiyonları: Küresel bir salgın. Klimik Dergisi 2017;30:49-58

123. Pasha AK, Lee JZ, Low SW, Desai H, Lee KS, Al Mohajer M. Fungal endocarditis: update on diagnosis and management. Am J Med 2016;129:1037-43.

124. Yuan SM. Fungal Endocarditis. Braz J Cardiovasc Surg 2016;31:252-5.

125. Meshaal MS, Labib D, Said K, Hosny M, Hassan M, Abd Al Aziz S, et al. Aspergillus endocarditis: Diagnostic criteria and predictors of outcome, A retrospective cohort study. PLoS One 2018;13:e0201459.

126. Işik S, Tavazar S, Ünalan N, Heybeli I, Ergüney E, Pişkinpaşa $\mathrm{ME}$, et al. Infektif endokarditte klinik ve patolojik bulguların korelasyonu. İstanbul Tip Dergisi 2001;4:13-7.

127. Gouriet F, Chaudet H, Gautret P, Pellegrin L, de Santi VP, Savini H, et al. Endocarditis in the Mediterranean Basin. New Microbes New Infect 2018;26:S43-S51.

128. Galley HF, Webster NR. Physiology of the endothelium. $\mathrm{Br}$ J Anaesth. 2004;93:105-13.

129. Forner L, Larsen T, Kilian M, Holmstrup P. Incidence of bacteremia after chewing, tooth brushing and scaling in individuals with periodontal inflammation. J Clin Periodontol 2006;33:401-7.

130. Werdan K, Dietz S, Löffler B, Niemann S, Bushnaq H, Silber RE, et al. Mechanisms of infective endocarditis: pathogen-host interaction and risk states. Nat Rev Cardiol 2014;11:35-50.

131. Liu J, Frishman WH. Nonbacterial thrombotic endocarditis: pathogenesis, diagnosis, and management. Cardiol Rev 2016;24:244-7.

132. Veloso TR, Chaouch A, Roger T, Giddey M, Vouillamoz J, Majcherczyk P, et al. Use of a human-like low-grade bacteremia model of experimental endocarditis to study the role of Staphylococcus aureus adhesins and 
platelet aggregation in early endocarditis. Infect Immun 2013;81:697-703.

133. Moser C, Pedersen HT, Lerche CJ, Kolpen M, Line L, Thomsen K, et al. Biofilms and host response - helpful or harmful. APMIS 2017;125:320-38.

134. Steyers CM 3rd, Miller FJ Jr. Endothelial dysfunction in chronic inflammatory diseases. Int $\mathrm{J}$ Mol Sci 2014;15:11324-49.

135. Elgharably H, Hussain ST, Shrestha NK, Blackstone EH, Pettersson GB. Current hypotheses in cardiac surgery: biofilm in infective endocarditis. Semin Thorac Cardiovasc Surg. Spring 2016;28:56-9.

136. Piper C, Körfer R, Horstkotte D. Prosthetic valve endocarditis. Heart 2001;85:590-3.

137. Yang E, Frazee BW. Infective Endocarditis. Emerg Med Clin North Am 2018;36:645-63.

138. Fernández Guerrero ML, Álvarez B, Manzarbeitia F, Renedo G. Infective endocarditis at autopsy: a review of pathologic manifestations and clinical correlates. Medicine (Baltimore) 2012;91:152-64.

139. Wang A, Gaca JG, Chu VH. Management considerations in infective endocarditis: A review. JAMA 2018;320:72-83.

140. Thuny F, Grisoli D, Collart F, Habib G, Raoult D. Management of infective endocarditis: challenges and perspectives. Lancet 2012;379:965-75.

141. Li JS, Sexton DJ, Mick N, Nettles R, Fowler VG Jr, Ryan $\mathrm{T}$, et al. Proposed modifications to the Duke criteria for the diagnosis of infective endocarditis. Clin Infect Dis 2000;30:633-8.

142. Dhawan VK. Infective endocarditis in elderly patients. Curr Infect Dis Rep 2003;5:285-92.

143. Chirillo F. It is not how old you are, it is how you are old: need for changes in the management of infective endocarditis in the elderly. Heart 2017;103:1562-4.

144. Cornelissen CG, Frechen DA, Schreiner K, Marx N, Krüger S. Inflammatory parameters and prediction of prognosis in infective endocarditis. BMC Infect Dis 2013;13:272.

145. Vollmer T, Piper C, Kleesiek K, Dreier J. Lipopolysaccharide-binding protein: a new biomarker for infectious endocarditis? Clin Chem 2009;55:295-304.

146. Messias-Reason IJ, Hayashi SY, Nisihara RM, Kirschfink M. Complement activation in infective endocarditis: correlation with extracardiac manifestations and prognosis. Clin Exp Immunol 2002;127:310-5.

147. Barrier J, Roblot P, Ramassamy A, Becq-Giraudon B. Immunologic studies in the differential diagnosis of infectious endocarditis and septicemia without endocardiac lesion. Rev Med Interne 1996;17:21-4.

148. Cabane J, Godeau P, Herreman G, Acar J, Digeon M, Bach JF. Fate of circulating immune complexes in infective endocarditis. Am J Med 1979;66:277-82.

149. Bosch X, Guilabert A, Font J. Antineutrophil cytoplasmic antibodies. Lancet 2006;368:404-18.

150. Konstantinov KN, Ulff-Møller CJ, Tzamaloukas AH. Infections and antineutrophil cytoplasmic antibodies: triggering mechanisms. Autoimmun Rev 2015;14:201-3.

151. Husmann CA, Holle JU, Moosig F, Mueller S, Wilde B, Cohen Tervaert JW, et al. Genetics of toll like receptor
9 in ANCA associated vasculitides. Ann Rheum Dis 2014;73:890-6.

152. Jennette JC, Falk RJ. Pathogenesis of antineutrophil cytoplasmic autoantibody-mediated disease. Nat Rev Rheumatol 2014;10:463-73.

153. Kain R, Rees AJ. What is the evidence for antibodies to LAMP-2 in the pathogenesis of ANCA associated small vessel vasculitis? Curr Opin Rheumatol 2013;25:26-34.

154. Yipp BG, Petri B, Salina D, Jenne CN, Scott BN, Zbytnuik $\mathrm{LD}$, et al. Infection-induced NETosis is a dynamic process involving neutrophil multitasking in vivo. Nat Med 2012;18:1386-93.

155. Gagliardi JP, Nettles RE, McCarty DE, Sanders LL, Corey GR, Sexton DJ. Native valve infective endocarditis in elderly and younger adult patients: comparison of clinical features and outcomes with use of the Duke criteria and the Duke Endocarditis Database. Clin Infect Dis 1998;26:1165-8.

156. Mahr A, Batteux F, Tubiana S, Goulvestre C, Wolff M, Papo T, et al. Brief report: prevalence of antineutrophil cytoplasmic antibodies in infective endocarditis. Arthritis Rheumatol 2014;66:1672-7.

157. Konstantinov KN, Emil SN, Barry M, Kellie S, Tzamaloukas AH. Glomerular disease in patients with infectious processes developing antineutrophil cytoplasmic antibodies. ISRN Nephrol 2013;2013:324315.

158. Langlois V, Lesourd A, Girszyn N, Ménard JF, Levesque $\mathrm{H}$, Caron F, et al. Antineutrophil Cytoplasmic Antibodies Associated With Infective Endocarditis. Medicine (Baltimore) 2016;95:e2564.

159. Zaratzian C, Gouriet F, Tissot-Dupont H, Casalta JP, Million M, Bardin N, et al. Antiphospholipid antibodies proposed in the diagnosis of infective endocarditis. Eur $\mathbf{J}$ Clin Microbiol Infect Dis 2017;36:1159-62.

160. Brouqui P, Dupont HT, Drancourt M, Berland Y, Etienne J, Leport C, et al. Chronic Q fever. Ninety-two cases from France, including 27 cases without endocarditis. Arch Intern Med 1993;153:642-8.

161. Gouriet F, Bothelo-Nevers E, Coulibaly B, Raoult D, Casalta JP. Evaluation of sedimentation rate, rheumatoid factor, C-reactive protein, and tumor necrosis factor for the diagnosis of infective endocarditis. Clin Vaccine Immunol 2006; 13:301.

162. Durack DT, Lukes AS, Bright DK. New criteria for diagnosis of infective endocarditis: utilization of specific echocardiographic findings. Duke Endocarditis Service. Am J Med 1994;96:200-9.

163. Capo C, Zugun F, Stein A, Tardei G, Lepidi H, Raoult $\mathrm{D}$, et al. Upregulation of tumor necrosis factor alpha and interleukin-1 beta in Q fever endocarditis. Infect Immun 1996;64:1638-42.

164. Lamas CC, Eykyn SJ. Suggested modifications to the Duke criteria for the clinical diagnosis of native valve and prosthetic valve endocarditis: analysis of 118 pathologically proven cases. Clin Infect Dis 1997;25:713-9.

165. Deck C, Guarda E, Bianchí C, Ortega C, Grisanti M, Vega $P$, et al. Circulating immune complexes in infective endocarditis. Rev Med Chil 1988;116:1101-4. 
166. Kauffmann RH, Thompson J, Valentijn RM, Daha MR, Van Es LA. The clinical implications and the pathogenetic significance of circulating immune complexes in infective endocarditis. Am J Med 1981;71:17-25.

167. Bayer AS, Theofilopoulos AN, Eisenberg R, Dixon FJ, Guze LB. Circulating immune complexes in infective endocarditis. N Engl J Med 1976;295:1500-5.

168. Thoker ZA, Khan KA, Rashid I, Zafar. Correlation of cardiac troponin I levels with infective endocarditis \& its adverse clinical outcomes. Int J Cardiol 2016;222:661-4.

169. Kahveci G, Bayrak F, Mutlu B, Bitigen A, Karaahmet T, Sonmez K, et al. Prognostic value of N-terminal pro-Btype natriuretic peptide in patients with active infective endocarditis. Am J Cardiol 2007;99:1429-33.

170. Gunebakmaz O, Kaya MG, Kaya EG, Ardic I, Yarlioglues M, Dogdu O, et al. Mean platelet volume predicts embolic complications and prognosis in infective endocarditis. Int $\mathbf{J}$ Infect Dis 2010;14:e982-5.

171. Ponasenko AV, Kutikhin AG, Khutornaya MV, Rutkovskaya $\mathrm{NV}$, Kondyukova NV, Odarenko YN, et al. Inherited Variation in Cytokine, Acute Phase Response, and Calcium Metabolism Genes Affects Susceptibility to Infective Endocarditis. Mediators Inflamm 2017;2017:7962546.

172. Shevchenko IuL, Danil'chenko VV,ZhiburtEB, Serebrianaia NB, Khubulava GG, Katkova IV. The immunogenetic status of patients with infectious endocarditis. Vestn Khir Im I I Grek 1995;154:58-63.

173. Habib G, Badano L, Tribouilloy C, Vilacosta I, Zamorano $\mathrm{JL}$, Galderisi M, et al. Recommendations for the practice of echocardiography in infective endocarditis. Eur J Echocardiogr 2010;11:202-19.

174. Wong D, Rubinshtein R, Keynan Y. Alternative cardiac imaging modalities to echocardiography for the diagnosis of infective endocarditis. Am J Cardiol 2016;118:1410-8.

175. Gomes A, Glaudemans AWJM, Touw DJ, van Melle JP, Willems TP, Maass AH, et al. Diagnostic value of imaging in infective endocarditis: a systematic review. Lancet Infect Dis 2017;17:e1-e14.

176. Gomes A, van Geel PP, Santing M, Prakken NHJ, Ruis ML, van Assen S, et al. Imaging infective endocarditis: Adherence to a diagnostic flowchart and direct comparison of imaging techniques. J Nucl Cardiol 2018 Jul 31. [Epub ahead of print]

177. Young WJ, Jeffery DA, Hua A, Primus C, Serafino Wani $\mathrm{R}$, Das S, et al. Echocardiography in patients with infective endocarditis and the impact of diagnostic delays on clinical outcomes. Am J Cardiol 2018;122:650-5.

178. Harding D, Prendergast B. Advanced imaging improves the diagnosis of infective endocarditis. F1000Res 2018;7. pii: F1000.

179. Thuny F, Di Salvo G, Belliard O, Avierinos JF, Pergola V, Rosenberg V, et al. Risk of embolism and death in infective endocarditis: prognostic value of echocardiography: a prospective multicenter study. Circulation 2005;112:69-75.

180. Mügge A, Daniel WG, Frank G, Lichtlen PR. Echocardiography in infective endocarditis: reassessment of prognostic implications of vegetation size determined by the transthoracic and the transesophageal approach. J Am Coll Cardiol 1989;14:631-8.

181. García-Cabrera E, Fernández-Hidalgo N, Almirante B, Ivanova-Georgieva $\mathrm{R}$, Noureddine $\mathrm{M}$, Plata $\mathrm{A}$, et al. Neurological complications of infective endocarditis: risk factors, outcome, and impact of cardiac surgery: a multicenter observational study. Circulation 2013;127:2272-84

182. Yang A, Tan C, Daneman N, Hansen MS, Habib G, Salaun $\mathrm{E}$, et al. Clinical and echocardiographic predictors of embolism in infective endocarditis: systematic review and meta-analysis. Clin Microbiol Infect 2019;25:178-87.

183. Mohananey D, Mohadjer A, Pettersson G, Navia J, Gordon $\mathrm{S}$, Shrestha N, et al. Association of vegetation size with embolic risk in patients with infective endocarditis: A systematic review and meta-analysis. JAMA Intern Med 2018;178:502-10.

184. Rohmann S, Erhel R, Darius H, Makowski T, Meyer J. Effect of antibiotic treatment on vegetation size and complication rate in infective endocarditis. Clin Cardiol 1997;20:132-40.

185. Manzano C, Vilacosta I, Fernández C, San Román JA, Sarriá C, Pozo E, López J, et al. Evolution of vegetation size in left-sided endocarditis. Is it a prognostic factor during hospitalization? Rev Esp Cardiol 2011;64:714-7.

186. Manzano MC, Vilacosta I, San Román JA, Aragoncillo P, Sarriá C, López D, et al. Acute coronary syndrome in infective endocarditis. Rev Esp Cardiol 2007;60:24-31.

187. Parra JA, Hernández L, Muñoz P, Blanco G, RodríguezÁlvarez R, Vilar DR, et al. Detection of spleen, kidney and liver infarcts by abdominal computed tomography does not affect the outcome in patients with left-side infective endocarditis. Medicine (Baltimore) 2018;97:e11952.

188. Madoff LC. Splenic abscess. In: Bennett JE, Dolin R, Blaser MJ, editors. Mandell, Douglas, and Bennett's Principles and Practice of Infectious Diseases. 8th ed. Philadelphia: Elsevier Saunders; 2015. p. 979-81.

189. Dursun M, Yilmaz S, Yilmaz E, Yilmaz R, Onur İ, Oflaz $\mathrm{H}$, et al. The utility of cardiac MRI in diagnosis of infective endocarditis: preliminary results. Diagn Interv Radiol 2015;21:28-33.

190. Duval X, Iung B, Klein I, Brochet E, Thabut G, Arnoult F, et al. Effect of early cerebral magnetic resonance imaging on clinical decisions in infective endocarditis: a prospective study. Ann Intern Med 2010;152:497-504.

191. Kouijzer IJ, Bleeker-Rovers CP, Oyen WJ. 18F-FDG PET/ CT for the detection of septic embolisms in patients with infectious endocarditis. J Nucl Med 2014;55:1045-6.

192. Bonfiglioli R, Nanni C, Morigi JJ, Graziosi M, Trapani F, Bartoletti M, et al. 18F-FDG PET/CT diagnosis of unexpected extracardiac septic embolisms in patients with suspected cardiac endocarditis. Eur J Nucl Med Mol Imaging 2013;40:1190-6.

193. Bertagna F, Bisleri G, Motta F, Merli G, Cossalter E, Lucchini S, et al. Possible role of F18-FDG-PET/CT in the diagnosis of endocarditis: preliminary evidence from a review of the literature. Int J Cardiovasc Imaging 2012;28:1417-25. 
194. Coulden R, Chung P, Sonnex E, Ibrahim Q, Maguire C, Abele J. Suppression of myocardial 18F-FDG uptake with a preparatory "Atkins-style" low-carbohydrate diet. Eur Radiol 2012;22:2221-8.

195. Caldarella C, Leccisotti L, Treglia G, Giordano A. Which is the optimal acquisition time for FDG PET/CT imaging in patients with infective endocarditis? J Nucl Cardiol 2013;20:307-9.

196. Chen W, Kim J, Molchanova-Cook OP, Dilsizian V. The potential of FDG PET/CT for early diagnosis of cardiac device and prosthetic valve infection before morphologic damages ensue. Curr Cardiol Rep 2014;16:459.

197. Pizzi MN, Roque A, Cuéllar-Calabria H, FernándezHidalgo N, Ferreira-González I, González-Alujas MT, et al. 18F-FDG-PET/CTA of Prosthetic cardiac valves and valve-tube grafts: infective versus inflammatory patterns. JACC Cardiovasc Imaging 2016;9:1224-7.

198. Roca M, de Vries EF, Jamar F, Israel O, Signore A. Guidelines for the labelling of leucocytes with (111) In-oxine. Inflammation/Infection Taskgroup of the European Association of Nuclear Medicine. Eur J Nucl Med Mol Imaging 2010;37:835-41.

199. de Vries EF, Roca M, Jamar F, Israel O, Signore A. Guidelines for the labelling of leucocytes with (99m) Tc-HMPAO. Inflammation/Infection Taskgroup of the European Association of Nuclear Medicine. Eur J Nucl Med Mol Imaging 2010;37:842-8.

200. Díez-Villanueva P, Muñoz P, Marín M, Bermejo J, de Alarcón González A, Fariñas MC, et al. Infective endocarditis: Absence of microbiological diagnosis is an independent predictor of inhospital mortality. Int J Cardiol 2016;220:162-5.

201. Pazin GJ, Saul S, Thompson ME. Blood culture positivity: suppression by outpatient antibiotic therapy in patients with bacterial endocarditis. Arch Intern Med 1982;142:263-8.

202. Hall KK, Lyman JA. Updated review of blood culture contamination. Clin Microbiol Rev 2006;19:788-802.

203. Lamy B, Dargère S, Arendrup MC, Parienti JJ, Tattevin P. How to optimize the use of blood cultures for the diagnosis of bloodstream infections? A State-of-the Art. Front Microbiol 2016;7:697.

204. Bouza E, Sousa D, Rodríguez-Créixems M, Lechuz JG, Muñoz P. Is the volume of blood cultured still a significant factor in the diagnosis of bloodstream infections? J Clin Microbiol 2007;45:2765-9.

205. Gould FK, Denning DW, Elliott TS, Foweraker J, Perry JD, Prendergast BD, et al. Guidelines for the diagnosis and antibiotic treatment of endocarditis in adults: a report of the Working Party of the British Society for Antimicrobial Chemotherapy. J Antimicrob Chemother 2012;67:269-89.

206. Klinik Mikrobiyoloji Uzmanlık Derneği. Tıbbi Mikrobiyoloji Uzmanları İçin Klinik Örnekten Sonuç Raporuna Uygulama Rehberi: Kan Dolaşımı Örnekleri. Ankara: Klinik Mikrobiyoloji Uzmanlık Derneği; 2017.

207. Towns ML, Jarvis WR, Hsueh PR. Guidelines on blood cultures. J Microbiol Immunol Infect 2010;43:347-9.
208. Muñoz P, Bouza E, Marín M, Alcalá L, Rodríguez Créixems M, Valerio M, et al. Heart valves should not be routinely cultured. J Clin Microbiol 2008;46:2897-901.

209. García-Granja PE, López J, Vilacosta I, Sarriá C, Ladrón $\mathrm{R}$, Olmos $\mathrm{C}$, et al. Impact of valve culture in the prognosis of active left-sided infective endocarditis. Clin Infect Dis 2019;68:1017-23.

210. Morris AJ, Drinkovic D, Pottumarthy S, Strickett MG, MacCulloch D, Lambie N, et al. Gram stain, culture, and histopathological examination findings for heart valves removed because of infective endocarditis. Clin Infect Dis 2003;36:697-704.

211. Subedi S, Jennings Z, Chen SC. Laboratory approach to the diagnosis of culture-negative infective endocarditis. Heart Lung Circ 2017;26:763-71.

212. Nawrot U, Kowalska-Krochmal B, Sulik-Tyszka B, Kozak M, Swietek K, Pajaczkowska M, et al. Evaluation of blood culture media for the detection of fungi. Eur J Clin Microbiol Infect Dis 2015;34:161-7.

213. Benslimani A, Fenollar F, Lepidi H, Raoult D. Bacterial zoonoses and infective endocarditis, Algeria. Emerg Infect Dis 2005;11:216-24.

214. Fournier PE, Mainardi JL, Raoult D. Value of microimmunofluorescence for diagnosis and follow-up of Bartonella endocarditis. Clin Diagn Lab Immunol 2002;9:795-801.

215. Dowell SF, Peeling RW, Boman J, Carlone GM, Fields BS, Guarner J, et al. Standardizing Chlamydia pneumoniae assays: recommendations from the Centers for Disease Control and Prevention (USA) and the Laboratory Centre for Disease Control (Canada). Clin Infect Dis 2001;33:492-503.

216. Gdoura R, Pereyre S, Frikha I, Hammami N, Clerc M, Sahnoun Y, et al. Culture-negative endocarditis due to Chlamydia pneumoniae. J Clin Microbiol 2002;40:718-20.

217. Moter A, Musci M, Schmiedel D. Molecular methods for diagnosis of infective endocarditis. Curr Infect Dis Rep 2010;12:244-52.

218. Fenollar F, Raoult D. Molecular diagnosis of bloodstream infections caused by non-cultivable bacteria. Int $\mathbf{J}$ Antimicrob Agents 2007;30 Suppl 1:S7-15.

219. Fenollar F, Raoult D. Molecular genetic methods for the diagnosis of fastidious microorganisms. APMIS 2004;112:785-807.

220. Breitkopf C, Hammel D, Scheld HH, Peters G, Becker $\mathrm{K}$. Impact of a molecular approach to improve the microbiological diagnosis of infective heart valve endocarditis. Circulation 2005;111:1415-21.

221. Miller RJ, Chow B, Pillai D, Church D. Development and evaluation of a novel fast broad-range $16 \mathrm{~S}$ ribosomal DNA PCR and sequencing assay for diagnosis of bacterial infective endocarditis: multi-year experience in a large Canadian healthcare zone and a literature review. BMC Infect Dis 2016;16:146.

222. Kühn C, Disqué C, Mühl H, Orszag P, Stiesch M, Haverich A. Evaluation of commercial universal rRNA gene PCR plus sequencing tests for identification of bacteria and fungi associated with infectious endocarditis. J Clin Microbiol 2011;49:2919-23. 
223. Brenner SA, Rooney JA, Manzewitsch P, Regnery RL. Isolation of Bartonella (Rochalimaea) henselae: effects of methods of blood collection and handling. J Clin Microbiol 1997;35:544-7.

224. Raoult D, Casalta JP, Richet H, Khan M, Bernit E, Rovery $\mathrm{C}$, et al. Contribution of systematic serological testing in diagnosis of infective endocarditis. J Clin Microbiol 2005;43:5238-42.

225. Brandão TJ, Januario-da-Silva CA, Correia MG, Zappa M, Abrantes JA, Dantas AM, et al. Histopathology of valves in infective endocarditis, diagnostic criteria and treatment considerations. Infection 2017;45:199-207.

226. Burke A, Tavora F, editors. Practical Cardiovascular Pathology. Philadelphia: Wolters Kluwer; 2011.

227. Miller DV, Revelo MP, editors. Diagnostic Pathology: Cardiovascular. 2nd ed. Philadelphia: Elsevier; 2018.

228. Lepidi H, Durack DT, Raoult D. Diagnostic methods current best practices and guidelines for histologic evaluation in infective endocarditis. Infect Dis Clin North Am 2002;16:339-61.

229. Siciliano RF, Strabelli TM, Zeigler R, Rodrigues C, Castelli JB, Grinberg M, et al. Infective endocarditis due to Bartonella spp. and Coxiella burnetii: experience at a cardiology hospital in Sao Paulo, Brazil. Ann N Y Acad Sci 2006;1078:215-22.

230. Lepidi H, Houpikian P, Liang Z, Raoult D. Cardiac valves in patients with $\mathrm{Q}$ fever endocarditis: microbiological, molecular, and histologic studies. J Infect Dis 2003;187:1097-106.

231. Eiken PW, Edwards WD, Tazelaar HD, McBane RD, Zehr KJ. Surgical pathology of nonbacterial thrombotic endocarditis in 30 patients, 1985-2000. Mayo Clin Proc 2001;76:1204-12.

232. Lepidi H, Coulibaly B, Casalta JP, Raoult D. Autoimmunohistochemistry: a new method for the histologic diagnosis of infective endocarditis. J Infect Dis 2006;193:1711-7.

233. Granados U, Fuster D, Pericas JM, Llopis JL, Ninot S, Quintana E, et al. Diagnostic Accuracy of 18F-FDG PET/ CT in Infective Endocarditis and Implantable Cardiac Electronic Device Infection: A Cross-Sectional Study. J Nucl Med 2016;57:1726-32.

234. Pinede L, Duhaut P, Loire R. Clinical presentation of left atrial cardiac myxoma. A series of 112 consecutive cases. Medicine (Baltimore) 2001;80:159-72.

235. Roldan CA, Tolstrup K, Macias L, Qualls CR, Maynard D, Charlton G, et al. Libman-Sacks Endocarditis: Detection, Characterization, and Clinical Correlates by ThreeDimensional Transesophageal Echocardiography. J Am Soc Echocardiogr 2015;28:770-9.

236. el-Shami K, Griffiths E, Streiff M. Nonbacterial thrombotic endocarditis in cancer patients: pathogenesis, diagnosis, and treatment. Oncologist 2007;12:518-23.

237. Park LP, Chu VH, Peterson G, Skoutelis A, Lejko-Zupa T, Bouza E, et al. Validated risk score for predicting 6-month mortality in infective endocarditis. J Am Heart Assoc 2016;5:e003016.

238. Mestres CA, Paré JC, Miró JM; Working Group on Infective Endocarditis of the Hospital Clínic de Barcelona.
Organization and Functioning of a Multidisciplinary Team for the Diagnosis and Treatment of Infective Endocarditis: A 30-year Perspective (1985-2014). Rev Esp Cardiol (Engl Ed) 2015;68:363-8.

239. Shiue AB, Stancoven AB, Purcell JB, Pinkston K, Wang A, Khera A, et al. Relation of level of B-type natriuretic peptide with outcomes in patients with infective endocarditis. Am J Cardiol 2010;106:1011-5.

240. Benoit M, Thuny F, Le Priol Y, Lepidi H, Bastonero $\mathrm{S}$, Casalta JP, et al. The transcriptional programme of human heart valves reveals the natural history of infective endocarditis. PLoS One 2010;5:e8939.

241. Erwin JP, Otto CM. Infective endocarditis: old problem, new guidelines and still much to learn. Heart 2014;100:996-8

242. González De Molina M, Fernández-Guerrero JC, Azpitarte J. Infectious endocarditis: degree of discordance between clinical guidelines recommendations and clinical practice. Rev Esp Cardiol 2002;55:793-800.

243. Delahaye F, Rial MO, de Gevigney G, Ecochard R, Delaye J. A critical appraisal of the quality of the management of infective endocarditis. J Am Coll Cardiol 1999;33:788-93.

244. Botelho-Nevers E, Thuny F, Casalta JP, Richet H, Gouriet F, Collart F, et al. Dramatic reduction in infective endocarditisrelated mortality with a management-based approach. Arch Intern Med 2009;169:1290-8.

245. Chirillo F, Scotton P, Rocco F, Rigoli R, Borsatto F, Pedrocco A, et al. Impact of a multidisciplinary management strategy on the outcome of patients with native valve infective endocarditis. Am J Cardiol 2013;112:1171-6.

246. Fernández-Hidalgo N, Almirante B, Tornos P, GonzálezAlujas MT, Planes AM, Larrosa MN, et al. Prognosis of left-sided infective endocarditis in patients transferred to a tertiary-care hospital--prospective analysis of referral bias and influence of inadequate antimicrobial treatment. Clin Microbiol Infect 2011;17:769-75.

247. Leibovici L. Aminoglycoside-containing antibiotic combinations for the treatment of bacterial endocarditis: an evidence-based approach. Int J Antimicrob Agents 2010;36:S46-9.

248. Davido B, Dinh A, Nemo EM, Makhloufi S, Leplay C, Salomon J. Efficacy of the switch to oral antibiotics in the treatment of non-Staphylococcus aureus infective endocarditis in non-severely ill patients. Clin Microbiol Infect 2017;23:124-5.

249. Mzabi A, Kernéis S, Richaud C, Podglajen I, FernandezGerlinger MP, Mainardi JL. Switch to oral antibiotics in the treatment of infective endocarditis is not associated with increased risk of mortality in non-severely ill patients. Clin Microbiol Infect 2016;22:607-12.

250. Iversen K, Ihlemann N, Gill SU, Madsen T, Elming H, Jensen KT, et al. Partial oral versus intravenous antibiotic treatment of endocarditis. N Engl J Med 2019;380:415-24.

251. Boucher HW. Partial oral therapy for osteomyelitis and endocarditis - Is It Time? N Engl J Med 2019;380:487-9.

252. Dickerman SA, Abrutyn E, Barsic B, Bouza E, Cecchi E, Moreno A, et al. The relationship between the initiation of antimicrobial therapy and the incidence of stroke in 
infective endocarditis: an analysis from the ICE Prospective Cohort Study (ICE-PCS). Am Heart J 2007;154:1086-94.

253. Pefanis A, Thauvin-Eliopoulos C, Eliopoulos GM, Moellering RC Jr. Activity of ampicillin-sulbactam and oxacillin in experimental endocarditis caused by beta-lactamase-hyperproducing Staphylococcus aureus. Antimicrob Agents Chemother 1993;37:507-11.

254. Backo M, Gaenger E, Burkart A, Chai YL, Bayer AS. Treatment of experimental staphylococcal endocarditis due to a strain with reduced susceptibility in vitro to vancomycin: efficacy of ampicillin-sulbactam. Antimicrob Agents Chemother 1999;43:2565-8.

255. Ramos MC, Ing M, Kim E, Witt MD, Bayer AS. Ampicillin-sulbactam is effective in prevention and therapy of experimental endocarditis caused by beta-lactamaseproducing coagulase-negative staphylococci. Antimicrob Agents Chemother 1996;40:97-101.

256. Lavoie SR, Wong ES, Coudron PE, Williams DS, Markowitz SM. Comparison of ampicillin-sulbactam with vancomycin for treatment of experimental endocarditis due to a betalactamase-producing, highly gentamicin-resistant isolate of Enterococcus faecalis. Antimicrob Agents Chemother 1993;37:1447-51.

257. Paul M, Zemer-Wassercug N, Talker O, Lishtzinsky Y, Lev B, Samra Z, et al. Are all beta-lactams similarly effective in the treatment of methicillin-sensitive Staphylococcus aureus bacteraemia? Clin Microbiol Infect 2011;17:1581-6.

258. García-de-la-Mària C, Pericas JM, Del Río A, Castañeda $\mathrm{X}$, Vila-Farrés X, Armero Y, et al. Early in vitro and in vivo development of high-level daptomycin resistance is common in mitis group Streptococci after exposure to daptomycin. Antimicrob Agents Chemother 2013;57:2319-25.

259. Bashore TM, Cabell C, Fowler V Jr. Update on infective endocarditis. Curr Probl Cardiol 2006;31:274-352.

260. Sinner SW, Tunkel A. Viridans streptococci, nutritionally variant streptococci, groups $\mathrm{C}$ and $\mathrm{G}$ streptococci, and other related organisms. In: Bennett JE, Dolin R, Blaser MJ, editors. Mandell, Douglas, and Bennett's Principles and Practice of Infectious Diseases. 8th ed. Philadelphia: Elsevier Saunders; 2015. p. 2349-61.

261. Knoll B, Tleyjeh IM, Steckelberg JM, Wilson WR, Baddour LM. Infective endocarditis due to penicillinresistant viridans group streptococci. Clin Infect Dis 2007;44:1585-92.

262. Fujitani S, Rowlinson MC, George WL. Penicillin G-resistant viridans group streptococcal endocarditis and interpretation of the American Heart Association's Guidelines for the Treatment of Infective Endocarditis. Clin Infect Dis 2008;46:1064-6.

263. Prabhu RM, Piper KE, Baddour LM, Steckelberg JM, Wilson WR, Patel R. Antimicrobial susceptibility patterns among viridans group streptococcal isolates from infective endocarditis patients from 1971 to 1986 and 1994 to 2002. Antimicrob Agents Chemother 2004;48:4463-5.

264. Berzeg-Deniz D, Şimşek-Yavuz S, Öcalmaz MŞ, ErenŞensoy A, Ertürk A, Çeken S. Penisilin G: Unutmak için çok mu erken?. In: Şimşek-Yavuz S, Timurkaynak F, editors.
XVII. Türk Klinik Mikrobiyoloji ve İnfeksiyon Hastalıkları Kongresi (25-29 Mart 2015, Antalya) Kitabı. İstanbul: Türk Klinik Mikrobiyoloji ve İnfeksiyon Hastalıkları Derneği; 2015. s. 121.

265. Versporten A, Bolokhovets G, Ghazaryan L, Abilova V, Pyshnik G, Spasojevic T, et al. Antibiotic use in eastern Europe: a cross-national database study in coordination with the WHO Regional Office for Europe. Lancet Infect Dis 2014; 14:381-7.

266. Süzük S, Kaşkatepe B, Çetin M. Antimicrobial susceptibility against penicillin, ampicillin and vancomycin of viridans group Streptococcus in oral microbiota of patients at risk of infective endocarditis. Infez Med 2016;24:190-3.

267. European Committee on Antimicrobial Susceptibility Testing. Breakpoint tables for interpretation of MICs and zone diameters. Version 8.1, valid from 2018-0515 [İnternet]. Basel, Switzerland: EUCAST. Available at: http://www.eucast.org/clinical_breakpoints/ [Accessed: May 01, 2019].

268. Finch RG, Eliopoulos GM. Safety and efficacy of glycopeptide antibiotics. J Antimicrob Chemother 2005;55 Suppl 2:ii5-13.

269. Baddour LM, Wilson WR, Bayer AS, Fowler VG Jr, Bolger AF, Levison ME, et al. Infective endocarditis: diagnosis, antimicrobial therapy, and management of complications: a statement for healthcare professionals from the Committee on Rheumatic Fever, Endocarditis, and Kawasaki Disease, Council on Cardiovascular Disease in the Young, and the Councils on Clinical Cardiology, Stroke, and Cardiovascular Surgery and Anesthesia, American Heart Association: endorsed by the Infectious Diseases Society of America. Circulation 2005;111:e394-434.

270. Arias CA, Murray BE. Enterococcus species, Streptococcus gallolyticus group, and Leuconostoc species. In: Bennett JE, Dolin R, Blaser MJ, editors. Mandell, Douglas, and Bennett's Principles and Practice of Infectious Diseases. 8th ed. Philadelphia: Elsevier Saunders; 2015:2328-39.

271. Miro JM, Pericas JM, del Rio A; Hospital Clinic Endocarditis Study Group. A new era for treating Enterococcus faecalis endocarditis: ampicillin plus short-course gentamicin or ampicillin plus ceftriaxone: that is the question! Circulation 2013;127:1763-6.

272. Nigo M, Munita JM, Arias CA, Murray BE. What's new in the treatment of enterococcal endocarditis? Curr Infect Dis Rep 2014;16:431.

273. Gavaldà J, Torres C, Tenorio C, López P, Zaragoza M, Capdevila JA, et al. Efficacy of ampicillin plus ceftriaxone in treatment of experimental endocarditis due to Enterococcus faecalis strains highly resistant to aminoglycosides. Antimicrob Agents Chemother 1999;43:639-46.

274. Gavaldà J, Len O, Miró JM, Muñoz P, Montejo M, Alarcón A, et al. Brief communication: treatment of Enterococcus faecalis endocarditis with ampicillin plus ceftriaxone. Ann Intern Med 2007;146:574-9.

275. Fernández-Hidalgo N, Almirante B, Gavaldà J, Gurgui M, Peña C, de Alarcón A, et al. Ampicillin plus ceftriaxone is as effective as ampicillin plus gentamicin for treating 
enterococcus faecalis infective endocarditis. Clin Infect Dis 2013;56:1261-8.

276. Birmingham MC, Rayner CR, Meagher AK, Flavin SM, Batts DH, Schentag JJ. Linezolid for the treatment of multidrug-resistant, gram-positive infections: experience from a compassionate-use program. Clin Infect Dis 2003;36:159-68.

277. Falagas ME, Manta KG, Ntziora F, Vardakas KZ. Linezolid for the treatment of patients with endocarditis: a systematic review of the published evidence. J Antimicrob Chemother 2006;58:273-80.

278. Miller WR, Murray BE, Rice LB, Arias CA. VancomycinResistant Enterococci: Therapeutic Challenges in the 21st Century. Infect Dis Clin North Am 2016;30:415-39.

279. Balli EP, Venetis CA, Miyakis S. Systematic review and meta-analysis of linezolid versus daptomycin for treatment of vancomycin-resistant enterococcal bacteremia. Antimicrob Agents Chemother 2014;58:734-9.

280. Britt NS, Potter EM, Patel N, Steed ME. Comparison of the effectiveness and safety of linezolid and daptomycin in vancomycin-resistant enterococcal bloodstream infection: a national cohort study of veterans affairs patients. Clin Infect Dis 2015;61:871-8.

281. Chuang YC, Lin HY, Chen PY, Lin CY, Wang JT, Chang SC. Daptomycin versus linezolid for the treatment of vancomycin-resistant enterococcal bacteraemia: implications of daptomycin dose. Clin Microbiol Infect 2016;22:890.e1-890.e7.

282. Chuang YC, Lin HY, Chen PY, Lin CY, Wang JT, Chen $\mathrm{YC}$, et al. Effect of daptomycin dose on the outcome of vancomycin-resistant, daptomycin-susceptible enterococcus faecium bacteremia. Clin Infect Dis 2017;64:1026-34.

283. Leenstra T, Woudt S, van Heereveld J, et al. Central Asian and Eastern European Surveillance of Antimicrobial Resistance, Annual Report 2017 [İnternet]. Geneva: World Health Organization. Available at: http://www. euro.who.int/__data/as-sets/pdf_file/0005/354434/WHO_ CAESAR_AnnualReport_2017.pdf?ua=1 [Accessed: Mayis 01, 2019].

284. Chang FY, Peacock JE Jr, Musher DM, Triplett P, MacDonald BB, Mylotte JM, et al. Staphylococcus aureus bacteremia: recurrence and the impact of antibiotic treatment in a prospective multicenter study. Medicine (Baltimore) 2003;82:333-9.

285. Rybak M, Lomaestro B, Rotschafer JC, Moellering R Jr, Craig W, Billeter M, et al. Therapeutic monitoring of vancomycin in adult patients: a consensus review of the American Society of Health-System Pharmacists, the Infectious Diseases Society of America, and the Society of Infectious Diseases Pharmacists. Am J Health Syst Pharm 2009;66:82-98.

286. Elyasi S, Khalili H, Dashti-Khavidaki S, Mohammadpour A. Vancomycin-induced nephrotoxicity: mechanism, incidence, risk factors and special populations. A literature review. Eur J Clin Pharmacol 2012;68:1243-55.

287. Kim SH, Kim KH, Kim HB, Kim NJ, Kim EC, Oh MD, et al. Outcome of vancomycin treatment in patients with methicillin-susceptible Staphylococcus aureus bacteremia.
Antimicrob Agents Chemother 2008;52:192-7.

288. Small PM, Chambers HF. Vancomycin for Staphylococcus aureus endocarditis in intravenous drug users. Antimicrob Agents Chemother 1990;34:1227-31.

289. McConeghy KW, Bleasdale SC, Rodvold KA. The empirical combination of vancomycin and a $\beta$-lactam for Staphylococcal bacteremia. Clin Infect Dis 2013;57:1760-5.

290. Park GE, Ko JH, Cho SY, Ha YE, Lee NY, Kang CI, et al. Empirical combination of a $\beta$-lactam to vancomycin may not improve outcomes of methicillinsusceptible Staphylococcus aureus bacteremia, compared to vancomycin monotherapy. Eur J Clin Microbiol Infect Dis 2017;36:1091-6.

291. Lee S, Choe PG, Song KH, Park SW, Kim HB, Kim NJ, et al. Is cefazolin inferior to nafcillin for treatment of methicillin-susceptible Staphylococcus aureus bacteremia? Antimicrob Agents Chemother 2011;55:5122-6.

292. Flynt LK, Kenney RM, Zervos MJ, Davis SL. The safety and economic impact of cefazolin versus nafcillin for the treatment of methicillin-susceptible staphylococcus aureus bloodstream infections. Infect Dis Ther 2017;6:225-31.

293. Li J, Echevarria KL, Traugott KA. $\beta$-Lactam Therapy for Methicillin-Susceptible Staphylococcus aureus Bacteremia: A Comparative Review of Cefazolin versus Antistaphylococcal Penicillins. Pharmacotherapy 2017;37:346-60.

294. McDanel JS, Roghmann MC, Perencevich EN, Ohl ME, Goto M, Livorsi DJ, et al. Comparative effectiveness of cefazolin versus nafcillin or oxacillin for treatment of methicillin-susceptible staphylococcus aureus infections complicated by bacteremia: A Nationwide Cohort Study. Clin Infect Dis 2017;65:100-6.

295. Davis JS, Turnidge J, Tong S. A large retrospective cohort study of cefazolin compared with flucloxacillin for methicillin-susceptible Staphylococcus aureus bacteraemia. Int J Antimicrob Agents 2018;52:297-300.

296. Pollett S, Baxi SM, Rutherford GW, Doernberg SB, Bacchetti P, Chambers HF. Cefazolin versus Nafcillin for MethicillinSensitive Staphylococcus aureus Bloodstream Infection in a California Tertiary Medical Center. Antimicrob Agents Chemother 2016;60:4684-9.

297. Lee S, Song KH, Jung SI, Park WB, Lee SH, Kim YS, et al. Comparative outcomes of cefazolin versus nafcillin for methicillin-susceptible Staphylococcus aureus bacteraemia: a prospective multicentre cohort study in Korea. Clin Microbiol Infect 2018;24:152-8.

298. Loubet P, Burdet C, Vindrios W, Grall N, Wolff M, Yazdanpanah Y, et al. Cefazolin versus anti-staphylococcal penicillins for treatment of methicillin-susceptible Staphylococcus aureus bacteraemia: a narrative review. Clin Microbiol Infect 2018;24:125-32.

299. Rao SN, Rhodes NJ, Lee BJ, Scheetz MH, Hanson AP, Segreti J, et al. Treatment outcomes with cefazolin versus oxacillin for deep-seated methicillin-susceptible Staphylococcus aureus bloodstream infections. Antimicrob Agents Chemother 2015;59:5232-8.

300. Bai AD, Showler A, Burry L, Steinberg M, Ricciuto DR, Fernandes T, et al. Comparative effectiveness of cefazolin versus cloxacillin as definitive antibiotic therapy for MSSA 
bacteraemia: results from a large multicentre cohort study. J Antimicrob Chemother 2015;70:1539-46.

301. Li J, Echevarria KL, Hughes DW, Cadena JA, Bowling JE, Lewis JS 2nd. Comparison of cefazolin versus oxacillin for treatment of complicated bacteremia caused by methicillinsusceptible Staphylococcus aureus. Antimicrob Agents Chemother 2014;58:5117-24.

302. Nannini EC, Singh KV, Arias CA, Murray BE. In vivo effects of cefazolin, daptomycin, and nafcillin in experimental endocarditis with a methicillin-susceptible Staphylococcus aureus strain showing an inoculum effect against cefazolin. Antimicrob Agents Chemother 2013;57:4276-81.

303. Nannini EC, Stryjewski ME, Singh KV, Bourgogne A, Rude $\mathrm{TH}$, Corey GR, et al. Inoculum effect with cefazolin among clinical isolates of methicillin-susceptible Staphylococcus aureus: frequency and possible cause of cefazolin treatment failure. Antimicrob Agents Chemother 2009;53:3437-41.

304. Murray RJ. Staphylococcus aureus infective endocarditis: diagnosis and management guidelines. Intern Med J 2005;35 Suppl 2:S25-44.

305. Nannini EC, Stryjewski ME, Singh KV, Rude TH, Corey GR, Fowler VG Jr, et al. Determination of an inoculum effect with various cephalosporins among clinical isolates of methicillin-susceptible Staphylococcus aureus. Antimicrob Agents Chemother 2010;54:2206-8.

306. Sonneville R, Mirabel M, Hajage D, Tubach F, Vignon P, Perez P, et al. Neurologic complications and outcomes of infective endocarditis in critically ill patients: the ENDOcardite en REAnimation prospective multicenter study. Crit Care Med 2011;39:1474-81.

307. Snygg-Martin U, Gustafsson L, Rosengren L, Alsiö A, Ackerholm P, Andersson R, et al. Cerebrovascular complications in patients with left-sided infective endocarditis are common: a prospective study using magnetic resonance imaging and neurochemical brain damage markers. Clin Infect Dis 2008;47:23-30.

308. Dien Bard J, Hindler JA, Gold HS, Limbago B. Rationale for eliminating Staphylococcus breakpoints for $\beta$-lactam agents other than penicillin, oxacillin or cefoxitin, and ceftaroline. Clin Infect Dis 2014;58:1287-96.

309. Patel UC, McKissic EL, Kasper D, Lentino JR, Pachucki CT, Lee T, et al. Outcomes of ceftriaxone use compared to standard of therapy in methicillin susceptible staphylococcal aureus (MSSA) bloodstream infections. Int J Clin Pharm 2014;36:1282-9.

310. Lother SA, Press N. Once-Daily Treatments for methicillinsusceptible Staphylococcus aureus Bacteremia: Are They Good Enough? Curr Infect Dis Rep 2017;19:43.

311. Kosowska-Shick K, McGhee PL, Appelbaum PC. Affinity of ceftaroline and other beta-lactams for penicillin-binding proteins from Staphylococcus aureus and Streptococcus pneumoniae. Antimicrob Agents Chemother 2010;54:1670-7.

312. Palmer SM, Kang SL, Cappelletty DM, Rybak MJ. Bactericidal killing activities of cefepime, ceftazidime, cefotaxime, and ceftriaxone against Staphylococcus aureus and beta-lactamase-producing strains of Enterobacter aerogenes and Klebsiella pneumoniae in an in vitro infection model. Antimicrob Agents Chemother 1995;39:1764-71.

313. Thwaites GE, Edgeworth JD, Gkrania-Klotsas E, Kirby A, Tilley R, Török ME, et al. Clinical management of Staphylococcus aureus bacteraemia. Lancet Infect Dis 2011;11:208-22.

314. Fowler VG Jr, Boucher HW, Corey GR, Abrutyn E, Karchmer AW, Rupp ME, et al. Daptomycin versus standard therapy for bacteremia and endocarditis caused by Staphylococcus aureus. N Engl J Med 2006;355:653-65.

315. Carugati M, Bayer AS, Miró JM, Park LP, Guimarães AC, Skoutelis A, et al. High-dose daptomycin therapy for leftsided infective endocarditis: a prospective study from the international collaboration on endocarditis. Antimicrob Agents Chemother 2013;57:6213-22.

316. van Hal SJ, Lodise TP, Paterson DL. The clinical significance of vancomycin minimum inhibitory concentration in Staphylococcus aureus infections: a systematic review and meta-analysis. Clin Infect Dis 2012;54:755-71.

317. Moore CL, Osaki-Kiyan P, Haque NZ, Perri MB, Donabedian S, Zervos MJ. Daptomycin versus vancomycin for bloodstream infections due to methicillin-resistant Staphylococcus aureus with a high vancomycin minimum inhibitory concentration: a case-control study. Clin Infect Dis 2012;54:51-8.

318. Kalil AC, Van Schooneveld TC, Fey PD, Rupp ME. Association between vancomycin minimum inhibitory concentration and mortality among patients with Staphylococcus aureus bloodstream infections: a systematic review and meta-analysis. JAMA 2014;312:1552-64.

319. Pericàs JM, Messina JA, Garcia-de-la-Mària C, Park L, Sharma-Kuinkel BK, Marco F, et al. Influence of vancomycin minimum inhibitory concentration on the outcome of methicillin-susceptible Staphylococcus aureus left-sided infective endocarditis treated with antistaphylococcal $\beta$-lactam antibiotics: a prospective cohort study by the International Collaboration on Endocarditis. Clin Microbiol Infect 2017;23:544-9.

320. Cervera C, Castañeda X, de la Maria CG, del Rio A, Moreno A, Soy D, et al. Effect of vancomycin minimal inhibitory concentration on the outcome of methicillinsusceptible Staphylococcus aureus endocarditis. Clin Infect Dis 2014;58:1668-75.

321. Kalimuddin S, Chan YFZ, Phillips R, Ong SP, Archuleta S, Lye DC, et al. A randomized phase $2 \mathrm{~B}$ trial of vancomycin versus daptomycin for the treatment of methicillin-resistant Staphylococcus aureus bacteremia due to isolates with high vancomycin minimum inhibitory concentrations - results of a prematurely terminated study. Trials 2018;19:305.

322. Liu C, Bayer A, Cosgrove SE, Daum RS, Fridkin SK, Gorwitz RJ, et al. Clinical practice guidelines by the infectious diseases society of america for the treatment of methicillin-resistant Staphylococcus aureus infections in adults and children: executive summary. Clin Infect Dis 2011;52:285-92.

323. Brown J, Brown K, Forrest A. Vancomycin AUC24/MIC ratio in patients with complicated bacteremia and infective endocarditis due to methicillin-resistant Staphylococcus aureus and its association with attributable mortality 
during hospitalization. Antimicrob Agents Chemother 2012;56:634-8.

324. Neely MN, Youn G, Jones B, Jelliffe RW, Drusano GL, Rodvold KA, et al. Are vancomycin trough concentrations adequate for optimal dosing? Antimicrob Agents Chemother. 2014;58:309-16.

325. Neely MN, Kato L, Youn G, Kraler L, Bayard D, van Guilder M, et al. Prospective trial on the use of trough concentration versus area under the curve to determine therapeutic vancomycin dosing. Antimicrob Agents Chemother 2018;62. Pii: e02042-17.

326. Badwal J. Vanquish thy troughs: targeting AUC/MIC for vancomycin dosing [İnternet]. Austin, TX: The University of Texas at Austin. Available at: http://sites.utexas.edu/ pharmacotherapy-rounds/files/2018/03/BadwalRR_ FinalHandout-without-pic-March-2018.pdf [Accessed: May 01, 2019]

327. Chavada R, Ghosh N, Sandaradura I, Maley M, Van Hal SJ. Establishment of an AUC0-24 threshold for nephrotoxicity is a step towards individualized vancomycin dosing for methicillin-resistant Staphylococcus aureus bacteremia. Antimicrob Agents Chemother. 2017;61. pii: e02535-16.

328. Castañeda X, García-de-la-Mària C, Gasch O, Pericas JM, Armero Y, Soy D, et al. AUC/MIC Pharmacodynamic Target Is Not a Good Predictor of Vancomycin Efficacy in Methicillin-Resistant Staphylococcus aureus Experimental Endocarditis. Antimicrob Agents Chemother 2017;61. pii: e02486-16.

329. Drew RH, Sakoulas G. Vancomycin: parenteral dosing, monitoring, and adverse effects in adults [İnternet]. Waltham, MA: UpToDate Inc. Available at: https:/www.uptodate.com/ contents/vancomycin-parenteral-dosing-monitoring-andadverse-effects-in-adults [Accessed: May 01, 2019].

330. Chambers HF, Sande MA. Teicoplanin versus nafcillin and vancomycin in the treatment of experimental endocarditis caused by methicillin-susceptible or -resistant Staphylococcus aureus. Antimicrob Agents Chemother 1984;26:61-4.

331. de Górgolas M, Avilés P, Verdejo C, Fernández Guerrero ML. Treatment of experimental endocarditis due to methicillinsusceptible or methicillin-resistant Staphylococcus aureus with trimethoprim-sulfamethoxazole and antibiotics that inhibit cell wall synthesis. Antimicrob Agents Chemother 1995;39:953-7.

332. Kaatz GW, Seo SM, Reddy VN, Bailey EM, Rybak MJ. Daptomycin compared with teicoplanin and vancomycin for therapy of experimental Staphylococcus aureus endocarditis. Antimicrob Agents Chemother 1990;34:2081-5.

333. Gilbert DN, Wood CA, Kimbrough RC. Failure of treatment with teicoplanin at 6 milligrams/kilogram/day in patients with Staphylococcus aureus intravascular infection. The Infectious Diseases Consortium of Oregon. Antimicrob Agents Chemother 1991;35:79-87.

334. Ueda T, Takesue Y, Nakajima K, Ichki K, Wada Y, Komatsu $\mathrm{M}$, et al. High-dose regimen to achieve novel target trough concentration in teicoplanin. J Infect Chemother 2014;20:43-7.
335. Lee CH, Tsai CY, Li CC, Chien CC, Liu JW. Teicoplanin therapy for MRSA bacteraemia: a retrospective study emphasizing the importance of maintenance dosing in improving clinical outcomes. J Antimicrob Chemother 2015;70:257-63.

336. Svetitsky S, Leibovici L, Paul M. Comparative efficacy and safety of vancomycin versus teicoplanin: systematic review and meta-analysis. Antimicrob Agents Chemother 2009;53:4069-79.

337. Dohmen PM, Guleri A, Capone A, Utili R, Seaton RA, González-Ramallo VJ, et al. Daptomycin for the treatment of infective endocarditis: results from a European registry. J Antimicrob Chemother 2013;68:936-42.

338. Gasch O, Camoez M, Domínguez MA, Padilla B, Pintado V, Almirante B, et al. Emergence of resistance to daptomycin in a cohort of patients with methicillin-resistant Staphylococcus aureus persistent bacteraemia treated with daptomycin. J Antimicrob Chemother 2014;69:568-71.

339. Holubar M, Meng L, Deresinski S. Bacteremia due to methicillin-resistant Staphylococcus aureus: New therapeutic approaches. Infect Dis Clin North Am 2016;30:491-507.

340. Senneville E, Caillon J, Calvet B, Jehl F. Towards a definition of daptomycin optimal dose: Lessons learned from experimental and clinical data. Int $\mathrm{J}$ Antimicrob Agents 2016;47:12-9.

341. García-de-la-Mària C, Gasch O, García-Gonzalez J, Soy D, Shaw E, Ambrosioni J, et al. The combination of daptomycin and fosfomycin has synergistic, potent, and rapid bactericidal activity against methicillin-resistant Staphylococcus aureus in a rabbit model of experimental endocarditis. Antimicrob Agents Chemother 2018;62. pii: e02633-17.

342. Claeys KC, Smith JR, Casapao AM, Mynatt RP, Avery L, Shroff A, et al. Impact of the combination of daptomycin and trimethoprim-sulfamethoxazole on clinical outcomes in methicillin-resistant Staphylococcus aureus infections. Antimicrob Agents Chemother 2015;59:1969-76.

343. Miró JM, Entenza JM, Del Río A, Velasco M, Castañeda X, Garcia de la Mària C, et al. High-dose daptomycin plus fosfomycin is safe and effective in treating methicillinsusceptible and methicillin-resistant Staphylococcus aureus endocarditis. Antimicrob Agents Chemother 2012;56:4511-5.

344. Smith JR, Yim J, Rice S, Stamper K, Kebriaei R, Rybak MJ. Combination of tedizolid and daptomycin against methicillin-resistant Staphylococcus aureus in an in vitro model of simulated endocardial vegetations. Antimicrob Agents Chemother 2018;62. pii: e00101-18.

345. Zainah H, Zervos M, Stephane W, Chamas Alhelo S, Alkhoury G, Weinmann A. Daptomycin failure for treatment of pulmonary septic emboli in native tricuspid and mitral valve methicillin-resistant Staphylococcus aureus endocarditis. Case Rep Infect Dis 2013;2013:653582.

346 ClinicalTrials.gov. Database. A phase 3 telavancin Staphylococcus aureus (S. aureus) bacteremia trial [İnternet]. Bethesda, MD: National Institutes of Health. Available at: https://clinicaltrials.gov/ct2/show/NCT02208063 [Accessed: May 01, 2019]. 
347. Dilworth TJ, Ibrahim O, Hall P, Sliwinski J, Walraven C, Mercier RC. $\beta$-Lactams enhance vancomycin activity against methicillin-resistant Staphylococcus aureus bacteremia compared to vancomycin alone. Antimicrob Agents Chemother 2014;58:102-9.

348. Davis JS, Sud A, O'Sullivan MVN, Robinson JO, Ferguson $\mathrm{PE}, \mathrm{Foo} \mathrm{H}$, et al. Combination of vancomycin and $\beta$-lactam therapy for methicillin-resistant Staphylococcus aureus bacteremia: a pilot multicenter randomized controlled trial. Clin Infect Dis 2016;62:173-80.

349. Jang HC, Kim SH, Kim KH, Kim CJ, Lee S, Song $\mathrm{KH}$, et al. Salvage treatment for persistent methicillinresistant Staphylococcus aureus bacteremia: efficacy of linezolid with or without carbapenem. Clin Infect Dis 2009;49:395-401.

350. Seah J, Lye DC, Ng TM, Krishnan P, Choudhury S, Teng CB. Vancomycin monotherapy vs. combination therapy for the treatment of persistent methicillin-resistant Staphylococcus aureus bacteremia. Virulence 2013;4:734-9.

351. Kullar R, Casapao AM, Davis SL, Levine DP, Zhao JJ, Crank CW, et al. A multicentre evaluation of the effectiveness and safety of high-dose daptomycin for the treatment of infective endocarditis. J Antimicrob Chemother 2013;68:2921-6.

352. Cosgrove SE, Vigliani GA, Fowler VG Jr, Abrutyn E, Corey GR, Levine DP, et al. Initial low-dose gentamicin for Staphylococcus aureus bacteremia and endocarditis is nephrotoxic. Clin Infect Dis 2009;48:713-21.

353. Riedel DJ, Weekes E, Forrest GN. Addition of rifampin to standard therapy for treatment of native valve infective endocarditis caused by Staphylococcus aureus. Antimicrob Agents Chemother 2008;52:2463-7.

354. Rieg S, Joost I, Weiß V, Peyerl-Hoffmann G, Schneider C, Hellmich $\mathrm{M}$, et al. Combination antimicrobial therapy in patients with Staphylococcus aureus bacteraemia-a post hoc analysis in 964 prospectively evaluated patients. Clin Microbiol Infect 2017;23:406.e1-406.e8.

355. Casalta JP, Zaratzian C, Hubert S, Thuny F, Gouriet F, Habib G, et al. Treatment of Staphylococcus aureus endocarditis with high doses of trimethoprim/sulfamethoxazole and clindamycin-Preliminary report. Int J Antimicrob Agents 2013;42:190-1.

356. Klompas M, Kalil AC. Colouring outside the guidelines. Clin Microbiol Infect 2017;23:691-2.

357. Tornos P, Iung B, Permanyer-Miralda G, Baron G, Delahaye $\mathrm{F}$, Gohlke-Bärwolf $\mathrm{Ch}$, et al. Infective endocarditis in Europe: lessons from the Euro heart survey. Heart 2005;91:571-5.

358. Hasbun R, Vikram HR, Barakat LA, Buenconsejo J, Quagliarello VJ. Complicated left-sided native valve endocarditis in adults: risk classification for mortality. JAMA 2003;289:1933-40.

359. Nadji G, Rusinaru D, Rémadi JP, Jeu A, Sorel C, Tribouilloy C. Heart failure in left-sided native valve infective endocarditis: characteristics, prognosis, and results of surgical treatment. Eur J Heart Fail 2009;11:668-75.

360. López J, Sevilla T, Vilacosta I, García H, Sarriá C, Pozo $\mathrm{E}$, et al. Clinical significance of congestive heart failure in prosthetic valve endocarditis. A multicenter study with 257 patients. Rev Esp Cardiol (Engl Ed) 2013;66:384-90.

361. Anguera I, Miro JM, Vilacosta I, Almirante B, Anguita M, Muñoz P, et al. Aorto-cavitary fistulous tract formation in infective endocarditis: clinical and echocardiographic features of 76 cases and risk factors for mortality. Eur Heart J 2005;26:288-97.

362. Piper C, Hetzer R, Körfer R, Bergemann R, Horstkotte D. The importance of secondary mitral valve involvement in primary aortic valve endocarditis; the mitral kissing vegetation. Eur Heart J 2002;23:79-86.

363. Ponikowski P, Voors AA, Anker SD, Bueno H, Cleland JG, Coats AJ, et al. 2016 ESC Guidelines for the diagnosis and treatment of acute and chronic heart failure: The Task Force for the diagnosis and treatment of acute and chronic heart failure of the European Society of Cardiology (ESC). Developed with the special contribution of the Heart Failure Association (HFA) of the ESC. Eur J Heart Fail 2016;18:891-975.

364. Kiefer T, Park L, Tribouilloy C, Cortes C, Casillo R, Chu V, et al. Association between valvular surgery and mortality among patients with infective endocarditis complicated by heart failure. JAMA 2011;306:2239-47.

365. Habib G, Tribouilloy C, Thuny F, Giorgi R, Brahim A, Amazouz M, et al. Prosthetic valve endocarditis: who needs surgery? A multicentre study of 104 cases. Heart 2005;91:954-9.

366. Chambers J, Sandoe J, Ray S, Prendergast B, Taggart D, Westaby S, et al. The infective endocarditis team: recommendations from an international working group. Heart 2014;100:524-7.

367. López J, Sevilla T, Vilacosta I, Sarriá C, Revilla A, Ortiz $\mathrm{C}$, et al. Prognostic role of persistent positive blood cultures after initiation of antibiotic therapy in left-sided infective endocarditis. Eur Heart J 2013;34:1749-54.

368. Habib G, Hoen B, Tornos P, Thuny F, Prendergast B, Vilacosta I, et al. Guidelines on the prevention, diagnosis, and treatment of infective endocarditis (new version 2009): the Task Force on the Prevention, Diagnosis, and Treatment of Infective Endocarditis of the European Society of Cardiology (ESC). Endorsed by the European Society of Clinical Microbiology and Infectious Diseases (ESCMID) and the International Society of Chemotherapy (ISC) for Infection and Cancer. Eur Heart J 2009;30:2369-413.

369. Vilacosta I, Graupner C, San Román JA, Sarriá C, Ronderos $\mathrm{R}$, Fernández C, et al. Risk of embolization after institution of antibiotic therapy for infective endocarditis. J Am Coll Cardiol 2002;39:1489-95.

370. Selton-Suty C, Maigrat CH, Devignes J, Goehringer F, Erpelding ML, Alla F, et al. Possible relationship between antiphospholipid antibodies and embolic events in infective endocarditis. Heart 2018;104:509-16.

371. Hubert S, Thuny F, Resseguier N, Giorgi R, Tribouilloy C, Le Dolley Y, et al. Prediction of symptomatic embolism in infective endocarditis: construction and validation of a risk calculator in a multicenter cohort. J Am Coll Cardiol 2013;62:1384-92. 
372. Takahashi Y, Izumi C, Miyake M, Imanaka M, Kuroda M, Nishimura S, et al. Diagnostic accuracy of the Embolic Risk French Calculator for symptomatic embolism with infective endocarditis among Japanese population. J Cardiol 2017;70:607-14.

373. Hess A, Klein I, Iung B, Lavallée P, Ilic-Habensus E, Dornic Q, et al. Brain MRI findings in neurologically asymptomatic patients with infective endocarditis. AJNR Am J Neuroradiol 2013;34:1579-84.

374. Goulenok T, Klein I, Mazighi M, Messika-Zeitoun D, Alexandra JF, Mourvillier B, et al. Infective endocarditis with symptomatic cerebral complications: contribution of cerebral magnetic resonance imaging. Cerebrovasc Dis 2013;35:327-36.

375. Merkler AE, Chu SY, Lerario MP, Navi BB, Kamel H. Temporal relationship between infective endocarditis and stroke. Neurology 2015;85:512-6.

376. Nishimura RA, Otto CM, Bonow RO, Carabello BA, Erwin JP 3rd, Fleisher LA, et al. 2017 AHA/ACC Focused Update of the 2014 AHA/ACC Guideline for the Management of Patients With Valvular Heart Disease: A Report of the American College of Cardiology/American Heart Association Task Force on Clinical Practice Guidelines. J Am Coll Cardiol 2017;70:252-89.

377. Pettersson GB, Coselli JS; Writing Committee, Pettersson GB, Coselli JS, Hussain ST, et al. 2016 The American Association for Thoracic Surgery (AATS) consensus guidelines: Surgical treatment of infective endocarditis: Executive summary. J Thorac Cardiovasc Surg 2017;153:1241-58.

378. Ferrera C, Vilacosta I, Fernández C, López J, Sarriá C, Olmos C, et al. Early surgery for acute-onset infective endocarditis. Eur J Cardiothorac Surg 2018;54:1060-6.

379. Tornos P, Gonzalez-Alujas T, Thuny F, Habib G. Infective endocarditis: the European viewpoint. Curr Probl Cardiol 2011;36:175-222.

380. Baumgartner H, Falk V, Bax JJ, De Bonis M, Hamm C, Holm PJ, et al. 2017 ESC/EACTS Guidelines for the management of valvular heart disease. Eur Heart J 2017:38:2739-91.

381. Kang DH, Lee S, Kim YJ, Kim SH, Kim DH, Yun SC, et al. Long-term results of early surgery versus conventional treatment for infective endocarditis trial. Korean Circ J 2016;46:846-850.

382. Tattevin P, Mainardi JL. Analysis of the 2015 American and European guidelines for the management of infective endocarditis. Med Mal Infect 2016;46:406-10.

383. Jia L, Wang Z, Fu Q, Bu H, Wei M. Could early surgery get beneficial in adult patients with active native infective endocarditis? A meta-analysis. Biomed Res Int 2017;2017:3459468.

384. Oliver L, Lepeule R, Moussafeur A, Fiore A, Lim P, Ternacle J. Early surgery in infective endocarditis: Why should we wait? Arch Cardiovasc Dis 2016;109:651-4.

385. Wilbring M, Irmscher L, Alexiou K, Matschke K, Tugtekin SM. The impact of preoperative neurological events in patients suffering from native infective valve endocarditis. Interact Cardiovasc Thorac Surg 2014;18:740-7.
386. Tam DY, Yanagawa B, Verma S, Ruel M, Fremes SE, Mazine A, et al. Early vs late surgery for patients with endocarditis and neurological injury: a systematic review and meta-analysis. Can J Cardiol 2018;34:1185-99.

387. Hodges KE, Hussain ST, Stewart WJ, Pettersson GB. Surgical management of infective endocarditis complicated by ischemic stroke. J Card Surg 2017;32:9-13.

388. Byrne JG, Rezai K, Sanchez JA, Bernstein RA, Okum E, Leacche M, et al. Surgical management of endocarditis: the society of thoracic surgeons clinical practice guideline. Ann Thorac Surg 2011;91:2012-9.

389. Misfeld M, Girrbach F, Etz CD, Binner C, Aspern KV, Dohmen PM, et al. Surgery for infective endocarditis complicated by cerebral embolism: a consecutive series of 375 patients. J Thorac Cardiovasc Surg 2014;147:1837-44.

390. Yanagawa B, Pettersson GB, Habib G, Ruel M, Saposnik G, Latter DA, et al. Surgical management of infective endocarditis complicated by embolic stroke: practical recommendations for clinicians. Circulation 2016;134:1280-92.

391. Delahaye F. Is early surgery beneficial in infective endocarditis? A systematic review. Arch Cardiovasc Dis 2011;104:35-44.

392. Thanavaro KL, Nixon JV. Endocarditis 2014: an update. Heart Lung 2014;43:334-7.

393. Weber C, Gassa A, Rokohl A, Sabashnikov A, Deppe AC, Eghbalzadeh K, et al. Severity of presentation, not sex, increases risk of surgery for infective endocarditis. Ann Thorac Surg 2019;107:1111-7.

394. De Feo M, Cotrufo M, Carozza A, De Santo LS, Amendolara $\mathrm{F}$, Giordano S, et al. The need for a specific risk prediction system in native valve infective endocarditis surgery. ScientificWorldJournal 2012;2012:307571.

395. Olmos C, Vilacosta I, Habib G, Maroto L, Fernández C, López J, et al. Risk score for cardiac surgery in active leftsided infective endocarditis. Heart 2017;103:1435-42.

396. Gatti G, Perrotti A, Obadia JF, Duval X, Iung B, Alla F, et al. Simple scoring system to predict in-hospital mortality after surgery for infective endocarditis. J Am Heart Assoc 2017;6. pii: e004806.

397. Mistiaen WP. What are the main predictors of in-hospital mortality in patients with infective endocarditis: a review. Scand Cardiovasc J 2018;52:58-68.

398. Tao E, Wan L, Wang W, Luo Y, Zeng J, Wu X. The prognosis of infective endocarditis treated with biological valves versus mechanical valves: A meta-analysis. PLoS One 2017;12:e0174519.

399. García-Granja PE, López J, Vilacosta I, Sarriá C, Ladrón $\mathrm{R}$, Olmos C, et al. Surgery changes prognosis in infective endocarditis: The importance of post-surgical clinical evolution. Eur J Intern Med 2018;55:52-6.

400. Alagna L, Park LP, Nicholson BP, Keiger AJ, Strahilevitz J, Morris A, et al. Repeat endocarditis: analysis of risk factors based on the International Collaboration on Endocarditis - Prospective Cohort Study. Clin Microbiol Infect 2014;20:566-75.

401. Thuny F, Giorgi R, Habachi R, Ansaldi S, Le Dolley Y, Casalta JP, et al. Excess mortality and morbidity in patients 
surviving infective endocarditis. Am Heart J 2012;164:94101.

402. Kervan Ü, Koç O, Özatik MA, Bayraktar G, Şener E, Çağlı K, et al. Distribution and service quality of the cardiovascular surgery clinics in Turkey. Turkish J Thorac Cardiovasc Surg 2011;19:483-9.

403. Østergaard L, Valeur N, Ihlemann N, Bundgaard H, Gislason G, Torp-Pedersen C, et al. Incidence of infective endocarditis among patients considered at high risk. Eur Heart J 2018;39:623-9.

404. Østergaard L, Valeur N, Ihlemann N, Smerup MH, Bundgaard H, Gislason $\mathrm{G}$, et al. Incidence and factors associated with infective endocarditis in patients undergoing left-sided heart valve replacement. Eur Heart J 2018;39:2668-75.

405. Ivanovic B, Trifunovic D, Matic S, Petrovic J, Sacic D, Tadic M. Prosthetic valve endocarditis - A trouble or a challenge? J Cardiol 2019;73:126-33.

406. Wang A, Athan E, Pappas PA, Fowler VG Jr, Olaison L, Paré C, et al. Contemporary clinical profile and outcome of prosthetic valve endocarditis. JAMA 2007;297:1354-61.

407. Kolte D, Goldsweig A, Kennedy KF, Abbott JD, Gordon PC, Sellke FW, et al. Comparison of incidence, predictors, and outcomes of early infective endocarditis after transcatheter aortic valve implantation versus surgical aortic valve replacement in the United States. Am J Cardiol 2018;122:2112-9.

408. Evangelista A, Gonzalez-Alujas MT. Echocardiography in infective endocarditis. Heart 2004;90:614-7.

409. Swart LE, Gomes A, Scholtens AM, Sinha B, Tanis W, Lam MGEH, et al. Improving the diagnostic performance of 18f-fluorodeoxyglucose positron-emission tomography/ computed tomography in prosthetic heart valve endocarditis. Circulation 2018;138:1412-27.

410 Bittencourt MS, Blankstein R. More evidence supporting fluorodeoxyglucose positron emission tomography for diagnosing prosthetic valve infective endocarditis. Circulation 2018;138:1428-30.

411. Saby L, Laas O, Habib G, Cammilleri S, Mancini J, Tessonnier L, et al. Positron emission tomography/computed tomography for diagnosis of prosthetic valve endocarditis: increased valvular 18F-fluorodeoxyglucose uptake as a novel major criterion. J Am Coll Cardiol 2013;61:2374-82.

412. Hindricks G, Camm J, Merkely B, Raatikainen P, Arnar DO. The EHRA White Book 2017. The Current Status of Cardiac Electrophysiology in ESC Member Countries [İnternet]. Sophia Antipolis, France: European Heart Rhythm Association. Available at: https://www.escardio.org/static_file/ Escardio/Subspecialty/EHRA/Publications/Documents/2017/ ehra-white-book-2017.pdf [Accessed: May 01, 2019].

413. Sohail RM, Wilson W, Baddour LM. Infections of nonvalvular cardiovascular devices. In: Bennett JE, Dolin R, Blaser MJ, editors. Mandell, Douglas, and Bennett's Principles and Practice of Infectious Diseases. 8th ed. Philadelphia: Elsevier Saunders; 2015. p. 1041-56.

414. Osmonov D, Ozcan KS, Erdinler I, Altay S, Yildirim E, Turkkan C, et al. Cardiac device-related endocarditis: 31-Years' experience. J Cardiol 2013;61:175-80.
415. Kusumoto FM, Schoenfeld MH, Wilkoff BL, Berul CI, Birgersdotter-Green UM, Carrillo R, et al. 2017 HRS expert consensus statement on cardiovascular implantable electronic device lead management and extraction. Heart Rhythm 2017;14:e503-e51.

416. Tarakji KG, Ellis CR, Defaye P, Kennergren C. Cardiac implantable electronic device infection in patients at risk. Arrhythm Electrophysiol Rev 2016;5:65-71.

417. Bongiorni MG, Tascini C, Tagliaferri E, Di Cori A, Soldati E, Leonildi A, et al. Microbiology of cardiac implantable electronic device infections. Europace 2012;14:1334-9.

418. Sohail MR, Uslan DZ, Khan AH, Friedman PA, Hayes DL, Wilson WR, et al. Risk factor analysis of permanent pacemaker infection. Clin Infect Dis 2007;45:166-73.

419. Sohail MR, Uslan DZ, Khan AH, Friedman PA, Hayes DL, Wilson WR, et al. Infective endocarditis complicating permanent pacemaker and implantable cardioverterdefibrillator infection. Mayo Clin Proc 2008;83:46-53.

420. Narducci ML, Pelargonio G, Russo E, Marinaccio L, Di Monaco A, Perna F, et al. Usefulness of intracardiac echocardiography for the diagnosis of cardiovascular implantable electronic device-related endocarditis. J Am Coll Cardiol 2013;61:1398-405.

421. Erba PA, Sollini M, Conti U, Bandera F, Tascini C, De Tommasi SM, et al. Radiolabeled WBC scintigraphy in the diagnostic workup of patients with suspected device-related infections. JACC Cardiovasc Imaging 2013;6:1075-86.

422. Grammes JA, Schulze CM, Al-Bataineh M, Yesenosky GA, Saari CS, Vrabel MJ, et al. Percutaneous pacemaker and implantable cardioverter-defibrillator lead extraction in 100 patients with intracardiac vegetations defined by transesophageal echocardiogram. J Am Coll Cardiol 2010;55:886-94.

423. Ruttmann E, Hangler HB, Kilo J, Höfer D, Müller LC, Hintringer F, et al. Transvenous pacemaker lead removal is safe and effective even in large vegetations: an analysis of 53 cases of pacemaker lead endocarditis. Pacing Clin Electrophysiol 2006;29:231-6.

424. Deharo JC, Bongiorni MG, Rozkovec A, Bracke F, Defaye P, Fernandez-Lozano I, et al. Pathways for training and accreditation for transvenous lead extraction: a European Heart Rhythm Association position paper. Europace 2012;14:124-34.

425. Wilkoff BL, Love CJ, Byrd CL, Bongiorni MG, Carrillo RG, Crossley GH 3rd, et al. Transvenous lead extraction: Heart Rhythm Society expert consensus on facilities, training, indications, and patient management: this document was endorsed by the American Heart Association (AHA). Heart Rhythm 2009;6:1085-104.

426. Pichlmaier M, Knigina L, Kutschka I, Bara C, Oswald H, Klein $\mathrm{G}$, et al. Complete removal as a routine treatment for any cardiovascular implantable electronic device-associated infection. J Thorac Cardiovasc Surg 2011;142:1482-90.

427. Durante-Mangoni E, Casillo R, Bernardo M, Caianiello C, Mattucci I, Pinto D, et al. High-dose daptomycin for cardiac implantable electronic device-related infective endocarditis. Clin Infect Dis 2012;54:347-54. 
428. Jan E, Camou F, Texier-Maugein J, Whinnett Z, Caubet O, Ploux S, et al. Microbiologic characteristics and in vitro susceptibility to antimicrobials in a large population of patients with cardiovascular implantable electronic device infection. J Cardiovasc Electrophysiol 2012;23:375-81.

429. Tumbarello M, Pelargonio G, Trecarichi EM, Narducci ML, Fiori B, Bellocci F, et al. High-dose daptomycin for cardiac implantable electronic device-related infective endocarditis caused by staphylococcal small-colony variants. Clin Infect Dis 2012;54:1516-7.

430. Tascini C, Bongiorni MG, Di Cori A, Di Paolo A, Polidori M, Tagliaferri E, et al. Cardiovascular implantable electronic device endocarditis treated with daptomycin with or without transvenous removal. Heart Lung 2012;41:e24-30.

431. Kornberger A, Schmid E, Kalender G, Stock UA, Doernberger V, Khalil M, et al. Bridge to recovery or permanent system implantation: an eight-year single-center experience in transvenous semipermanent pacing. Pacing Clin Electrophysiol 2013;36:1096-103.

432. Krahn AD, Longtin Y, Philippon F, Birnie DH, Manlucu J, Angaran P, et al. Prevention of Arrhythmia Device Infection Trial: The PADIT Trial. J Am Coll Cardiol 2018;72:3098-109.

433. Sexton DJ, Chu VH. Infective endocarditis in people who inject drugs [İnternet]. Waltham, MA: UpToDate Inc. Available at: https://www.uptodate.com/contents/infectiveendocarditis-in-people-who-inject-drugs [Accessed: May 01, 2019].

434. Akinosoglou K, Apostolakis E, Marangos M, Pasvol G. Native valve right sided infective endocarditis. Eur J Intern Med 2013;24:510-9.

435. Fleischauer AT, Ruhl L, Rhea S, Barnes E. Hospitalizations for endocarditis and associated health care costs among persons with diagnosed drug dependence - North Carolina, 2010-2015. MMWR Morb Mortal Wkly Rep 2017;66:569-73.

436. Schranz AJ, Fleischauer A, Chu VH, Wu LT, Rosen DL. Trends in drug use-associated infective endocarditis and heart valve surgery, 2007 to 2017: A study of statewide discharge data. Ann Intern Med 2019;170:31-40.

437. Number with a drug use disorders by substances, Turkey [İnternet]. Oxford: Our World in Data. Available at: https:// ourworldindata.org/grapher/number-with-drug-disordersby-substance?country=TUR [Accessed: May 01, 2019].

438. Millar BC, Moore JE. Antibiotic prophylaxis, body piercing and infective endocarditis. J Antimicrob Chemother 2004;53:123-6.

439. Chahoud J, Sharif Yakan A, Saad H, Kanj SS. Rightsided infective endocarditis and pulmonary infiltrates: An update. Cardiol Rev 2016;24:230-7.

440. Hussain ST, Witten J, Shrestha NK, Blackstone EH, Pettersson GB. Tricuspid valve endocarditis. Ann Cardiothorac Surg 2017;6:255-61.

441. Ortiz-Bautista C, López J, García-Granja PE, Sevilla T, Vilacosta I, Sarriá C, et al. Current profile of infective endocarditis in intravenous drug users: The prognostic relevance of the valves involved. Int J Cardiol 2015;187:472-4.
442. Müller KA, Zürn CS, Patrik H, Heuschmid M, Hetzel J, Henning A, et al. Massive haemoptysis in an intravenous drug user with infective tricuspid valve endocarditis. BMJ Case Rep 2010;2010. pii: bcr1020092404.

443. San Román JA, Vilacosta I, López J, Revilla A, Arnold R, Sevilla T, et al. Role of transthoracic and transesophageal echocardiography in right-sided endocarditis: one echocardiographic modality does not fit all. J Am Soc Echocardiogr 2012;25:807-14.

444. Ben-Ami R, Giladi M, Carmeli Y, Orni-Wasserlauf R, Siegman-Igra Y. Hospital-acquired infective endocarditis: should the definition be broadened? Clin Infect Dis 2004;38:843-50.

445. Benito N, Miró JM, de Lazzari E, Cabell CH, del Río A, Altclas J, et al. Health care-associated native valve endocarditis: importance of non-nosocomial acquisition. Ann Intern Med 2009;150:586-94.

446. Wu KS, Lee SS, Tsai HC, Wann SR, Chen JK, Sy $\mathrm{CL}$, et al. Non-nosocomial healthcare-associated infective endocarditis in Taiwan: an underrecognized disease with poor outcome. BMC Infect Dis 2011;11:221.

447. Yang F, Zhang B, Yu J, Shao L, Zhou P, Zhu L, et al. Epidemiology and the prognosis of healthcare-associated infective endocarditis in China: the significance of nonnosocomial acquisition. Emerg Microbes Infect 2015;4:e38.

448. Martín-Dávila P, Fortún J, Navas E, Cobo J, Jiménez-Mena M, Moya JL, et al. Nosocomial endocarditis in a tertiary hospital: an increasing trend in native valve cases. Chest 2005;128:772-9.

449. Hwang JW, Park SW, Cho EJ, Lee GY, Kim EK, Chang SA, et al. Risk factors for poor prognosis in nosocomial infective endocarditis. Korean J Intern Med 2018;33:102-12.

450. Panel on Antiretroviral Guidelines for Adults and Adolescents. Guidelines for the Use of Antiretroviral Agents in Adults and Adolescents with HIV [İnternet]. Washington, DC: Department of Health and Human Services. Available at: https:/aidsinfo.nih.gov/contentfiles/lvguidelines/ adultandadolescentgl.pdf [Accessed: May 01, 2019].

451. Freiberg MS, So-Armah K. HIV and cardiovascular disease: We need a mechanism, and we need a plan. J Am Heart Assoc 2016;4:e003411.

452. Søgaard OS, Reekie J, Ristola M, Jevtovic D, Karpov I, Beniowski M, et al. Severe bacterial non-aids infections in HIV-positive persons: incidence rates and risk factors. J Infect 2013;66:439-46.

453. Currie PF, Sutherland GR, Jacob AJ, Bell JE, Brettle RP, Boon NA. A review of endocarditis in acquired immunodeficiency syndrome and human immunodeficiency virus infection. Eur Heart J 1995;16:15-8.

454. Miró JM, del Río A, Mestres CA. Infective endocarditis in intravenous drug abusers and HIV-1 infected patients. Infect Dis Clin North Am 2002;16:273-95.

455. Gebo KA, Burkey MD, Lucas GM, Moore RD, Wilson LE. Incidence of, risk factors for, clinical presentation, and 1-year outcomes of infective endocarditis in an urban HIV cohort. J Acquir Immune Defic Syndr 2006;43:426-32.

456. Furuno JP, Johnson JK, Schweizer ML, Uche A, Stine OC, Shurland SM, et al. Community-associated methicillin- 
resistant Staphylococcus aureus bacteremia and endocarditis among HIV patients: a cohort study. BMC Infect Dis 2011;11:298.

457. Nahass RG, Weinstein MP, Bartels J, Gocke DJ. Infective endocarditis in intravenous drug users: a comparison of human immunodeficiency virus type 1-negative and -positive patients. J Infect Dis 1990;162:967-70.

458. Pulvirenti JJ, Kerns E, Benson C, Lisowski J, Demarais $\mathrm{P}$, Weinstein RA. Infective endocarditis in injection drug users: importance of human immunodeficiency virus serostatus and degree of immunosuppression. Clin Infect Dis 1996;22:40-5.

459. Taramasso L, Tatarelli P, Di Biagio A. Bloodstream infections in HIV-infected patients. Virulence 2016;7:320-8.

460. Pedro-Botet ML, Mòdol JM, Vallés X, Romeu J, Sopena N, Giménez M, et al. Changes in bloodstream infections in HIV-positive patients in a university hospital in Spain (1995-1997). Int J Infect Dis 2002;6:17-22.

461. Losa JE, Miro JM, Del Rio A, Moreno-Camacho A, Garcia F, Claramonte X, et al. Infective endocarditis not related to intravenous drug abuse in HIV-1-infected patients: report of eight cases and review of the literature. Clin Microbiol Infect 2003;9:45-54.

462. Miró JM, del Río A, Mestres CA. Infective endocarditis and cardiac surgery in intravenous drug abusers and HIV-1 infected patients. Cardiol Clin 2003;21:167-84.

463. Chong T, Alejo DE, Greene PS, Redmond JM, Sussman MS, Baumgartner WA, et al. Cardiac valve replacement in human immunodeficiency virus-infected patients. Ann Thorac Surg 2003;76:478-80.

464. Gansera LS, Eszlari E, Deutsch O, Eichinger WB, Gansera B. High-risk cardiac surgery in patients with intravenous drug abuse and/or active hepatitis C or HIV infection: An ethical discussion of six cases. Thorac Cardiovasc Surg 2016;64:2-5.

465. Forestier E, Fraisse T, Roubaud-Baudron C, Selton-Suty C, Pagani L. Managing infective endocarditis in the elderly: new issues for an old disease. Clin Interv Aging 2016;11:1199-206.

466. Oliver L, Lavoute C, Giorgi R, Salaun E, Hubert S, Casalta $\mathrm{JP}$, et al. Infective endocarditis in octogenarians. Heart 2017;103:1602-9.

467. Şimşek Yavuz S. Infective endocarditis in elderly patients. Turk Kardiyol Dern Ars 2017;45:56-63.

468. Pereira L, Machado A, Oliveira J, Almeida P, Bettencourt P. Infective endocarditis presenting as acute renal failure and unusual complications. Intern Med 2015;54:1259-63.

469. Kim B, Huh HJ, Chung DR, Kim WS, Ki CS, Lee NY. The first case of concurrent infective endocarditis and spondylitis caused by Streptococcus tigurinus. Ann Lab Med 2015;35:654-6.

470. Honarbakhsh S, Chowdhury M, Farooqi F, Deaner A. Syncope secondary to left ventricular outflow tract obstruction, an interesting presentation of infective endocarditis. BMJ Case Rep 2015;2015. pii: bcr2015211920.

471. Armiñanzas C, Fariñas-Alvarez C, Zarauza J, Muñoz P, González Ramallo V, Martínez Sellés M, et al. Role of age and comorbidities in mortality of patients with infective endocarditis. Eur J Intern Med 2019;64:63-71.

472. López J, Revilla A, Vilacosta I, Sevilla T, Villacorta E, Sarriá C, et al. Age-dependent profile of left-sided infective endocarditis: a 3-center experience. Circulation 2010;121:892-7.

473. Durante-Mangoni E, Bradley S, Selton-Suty C, Tripodi MF, Barsic B, Bouza E, et al. Current features of infective endocarditis in elderly patients: results of the International Collaboration on Endocarditis Prospective Cohort Study. Arch Intern Med 2008;168:2095-103.

474. Nasim A, Baqi S, Akhtar SF. Pseudomonas aeruginosa endocarditis in renal transplant recipients. Transpl Infect Dis 2012;14:180-3.

475. Avery RK, Barnes DS, Teran JC, Wiedemann HP, Hall G, Wacker $\mathrm{T}$, et al. Listeria monocytogenes tricuspid valve endocarditis with septic pulmonary emboli in a liver transplant recipient. Transpl Infect Dis 1999;1:284-7.

476. Nelson JK, Giraldeau G, Montoya JG, Deresinski S, Ho DY, Pham M. Donor-derived coccidioides immitis endocarditis and disseminated infection in the setting of solid organ transplantation. Open Forum Infect Dis 2016;3: ofw086.

477. George S, Varghese J, Chandrasekhar S, Perumalla R, Reddy MS, Jayanthi V, et al. Gram-negative bacteria causing infective endocarditis: Rare cardiac complication after liver transplantation. World J Hepatol 2013;5:296-7.

478. Sherman-Weber S, Axelrod P, Suh B, Rubin S, Beltramo $\mathrm{D}$, Manacchio $\mathrm{J}$, et al. Infective endocarditis following orthotopic heart transplantation: 10 cases and a review of the literature. Transpl Infect Dis 2004;6:165-70.

479. Regueiro F, Gutiérrez F, Mons R, Riancho G, Revuelta JM. Aspergillus endocarditis in lung transplant recipient: successful surgical treatment. Ann Thorac Surg 2013;96:321-3.

480. Morio F, Treilhaud M, Lepelletier D, Le Pape P, Rigal JC, Delile L, et al. Aspergillus fumigatus endocarditis of the mitral valve in a heart transplant recipient: a case report. Diagn Microbiol Infect Dis 2008;62:453-6.

481. Unic D, Starcevic B, Sicaja M, Baric D, Rudez I, Biocic S, et al. Aortic valve endocarditis in a transplanted heart after urethral instrumentation. Ann Thorac Surg 2013;96:e61-2.

482. Sayeed R, Drain AJ, Sivasothy PS, Large SR, Wallwork J. Aortic valve replacement for late infective endocarditis after heart-lung transplantation. Transplant Proc 2005;37:4537-9.

483. Goegele H, Ruttmann E, Aranda-Michel J, Kafka R, Stelzmueller I, Hausdorfer $\mathrm{H}$, et al. Fatal endocarditis due to extended spectrum betalactamase producing Klebsiella terrigena in a liver transplant recipient. Wien Klin Wochenschr 2007;119:385-6.

484. Moreira AL, Haslett PA, Symmans WF. Propionibacterium acnes as the cause of endocarditis in a liver transplant recipient. Clin Infect Dis 2000;30:224-6.

485. Szabó PR, Kertész A, Szerafin T, Fehérvári I, Zsom L, Balla J, et al. Infective endocarditis caused by Chlamydia pneumoniae after liver transplantation. Case report. Orv Hetil 2015;156:896-900. [Abstract]

486. Bentata Y. Physiopathological approach to infective endocarditis in chronic hemodialysis patients: left heart versus right heart involvement. Ren Fail 2017;39:432-9. 
487. Bhatia N, Agrawal S, Garg A, Mohananey D, Sharma A, Agarwal M, et al. Trends and outcomes of infective endocarditis in patients on dialysis. Clin Cardiol 2017;40:423-9.

488. Labriola L, Jadoul M. Haemodialysis is a major risk factor for infective endocarditis. Lancet 2016;388:339-40.

489. Süleymanlar G, Ateş K, Seyahi N, editörler. Türkiye'de Nefroloji, Diyaliz ve Transplantasyon Registry 2015. T.C. Sağlık Bakanlığı ve Türk Nefroloji Derneği Ortak Raporu. İstanbul: Türk Nefroloji Derneği; 2016.

490. Lewis SS, Sexton DJ. Metastatic complications of bloodstream infections in hemodialysis patients. Semin Dial 2013;26:47-53.

491. Sexton DJ. Vascular access infections in patients undergoing dialysis with special emphasis on the role and treatment of Staphylococcus aureus. Infect Dis Clin North Am 2001;15:731-42.

492. Hsiao CC, Weng CH, Li YJ, Wu HH, Chen YC, Chen YM, et al. Comparison of the clinical features and outcomes of infective endocarditis between hemodialysis and nonhemodialysis patients. Ther Clin Risk Manag 2017;13:663-8.

493. Nucifora G, Badano LP, Viale P, Gianfagna P, Allocca $\mathrm{G}$, Montanaro D, et al. Infective endocarditis in chronic haemodialysis patients: an increasing clinical challenge. Eur Heart J 2007;28:2307-12.

494. Holland TL, Arnold C, Fowler VG Jr. Clinical management of Staphylococcus aureus bacteremia: a review. JAMA 2014;312:1330-41.

495. Leither MD, Shroff GR, Ding S, Gilbertson DT, Herzog CA. Long-term survival of dialysis patients with bacterial endocarditis undergoing valvular replacement surgery in the United States. Circulation 2013;128:344-51.

496. Miller LM, Clark E, Dipchand C, Hiremath S, Kappel J, Kiaii M, et al. Hemodialysis tunneled catheter-related infections. Can J Kidney Health Dis 2016;3:2054358116669129.

497. Beathard GA. Bacterial colonization of thrombosed dialysis arteriovenous grafts. Semin Dial 2015;28:446-9.

498. Nassar GM, Ayus JC. Clotted arteriovenous grafts: a silent source of infection. Semin Dial 2000;13:1-3.

499. Farag M, Borst T, Sabashnikov A, Zeriouh M, Schmack B, Arif R, et al. Surgery for Infective Endocarditis: Outcomes and Predictors of Mortality in 360 Consecutive Patients. Med Sci Monit 2017;23:3617-26.

500. Chu VH, Park LP, Athan E, Delahaye F, Freiberger T, Lamas $\mathrm{C}$, et al. Association between surgical indications, operative risk, and clinical outcome in infective endocarditis: a prospective study from the International Collaboration on Endocarditis. Circulation 2015;131:131-40.

501. Sharma V, Candilio L, Hausenloy DJ. Infective endocarditis: An intensive care perspective. Trends Anaesth Crit Care 2012;2:36-41.

502. Karth GD, Koreny M, Binder T, Knapp S. Complicated infective endocarditis necessitating ICU admission: clinical course and prognosis. Crit Care 2002;6:149-54.

503. Keynan Y, Singal R, Kumar K, Arora RC, Rubinstein E. Infective endocarditis in the intensive care unit. Crit Care Clin 2013;29:923-51.
504. Mourvillier B, Trouillet JL, Timsit JF, Baudot J, Chastre J, Régnier B, et al. Infective endocarditis in the intensive care unit: clinical spectrum and prognostic factors in 228 consecutive patients. Intensive Care Med 2004;30:2046-52.

505. Georges H, Leroy O, Airapetian N, Lamblin N, Zogheib E, Devos $\mathrm{P}$, et al. Outcome and prognostic factors of patients with right-sided infective endocarditis requiring intensive care unit admission. BMC Infect Dis 2018;18:85.

506. Cantier M, Mazighi M, Klein I, Desilles JP, Wolff M, Timsit JF, et al. Neurologic complications of infective endocarditis: Recent findings. Curr Infect Dis Rep 2017;19:41.

507. Miranda-Montero S, Rodríguez-Esteban M, AlvarezAcosta L, Lubillo-Montenegro S, Pérez-Hernández $\mathrm{H}$, Llorens-León R. Infectious endocarditis in the intensive care unit. Med Intensiva 2012;36:460-6. [Abstract]

508. Leroy O, Georges H, Devos P, Bitton S, De Sa N, Dedrie $\mathrm{C}$, et al. Infective endocarditis requiring ICU admission: epidemiology and prognosis. Ann Intensive Care 2015;5:45.

509. Vincent JL, Rello J, Marshall J, Silva E, Anzueto A, Martin $\mathrm{CD}$, et al. International study of the prevalence and outcomes of infection in intensive care units. JAMA 2009;302:2323-9.

510. Fang G, Keys TF, Gentry LO, Harris AA, Rivera N, Getz $\mathrm{K}$, et al. Prosthetic valve endocarditis resulting from nosocomial bacteremia. A prospective, multicenter study. Ann Intern Med 1993;119:560-7.

511. El-Ahdab F, Benjamin DK Jr, Wang A, Cabell CH, Chu $\mathrm{VH}$, Stryjewski ME, et al. Risk of endocarditis among patients with prosthetic valves and Staphylococcus aureus bacteremia. Am J Med 2005;118:225-9.

512. Gouëllo JP, Asfar P, Brenet O, Kouatchet A, Berthelot G, Alquier P. Nosocomial endocarditis in the intensive care unit: an analysis of 22 cases. Crit Care Med 2000;28:377-82.

513. Miranda-Montero S, Rodríguez-Esteban M, AlvarezAcosta L, Lubillo-Montenegro S, Pérez-Hernández H, Llorens-León R. Infectious endocarditis in the intensive care unit. Med Intensiva 2012;36:460-6. [Abstract]

514. Tabah A, Koulenti D, Laupland K, Misset B, Valles J, Bruzzi de Carvalho $\mathrm{F}$, et al. Characteristics and determinants of outcome of hospital-acquired bloodstream infections in intensive care units: the EUROBACT International Cohort Study. Intensive Care Med 2012;38:1930-45.

515. Masse J, Elkalioubie A, Blazejewski C, Ledoux G, Wallet $\mathrm{F}$, Poissy J, et al. Colonization pressure as a risk factor of ICU-acquired multidrug resistant bacteria: a prospective observational study. Eur J Clin Microbiol Infect Dis 2017;36:797-805.

516. Pappas PG, Kauffman CA, Andes DR, Clancy CJ, Marr KA, Ostrosky-Zeichner L, et al. Clinical Practice Guideline for the Management of Candidiasis: 2016 Update by the Infectious Diseases Society of America. Clin Infect Dis 2016;62:e1-50.

517. Arnold CJ, Johnson M, Bayer AS, Bradley S, Giannitsioti E, Miró JM, et al. Candida infective endocarditis: an observational cohort study with a focus on therapy. Antimicrob Agents Chemother 2015;59:2365-73.

518. Haddad SH, Arabi YM, Memish ZA, Al-Shimemeri AA. Nosocomial infective endocarditis in critically ill patients: 
a report of three cases and review of the literature. Int $\mathrm{J}$ Infect Dis 2004;8:210-6.

519. Mermel LA. Short-term peripheral venous catheter-related bloodstream infections: A systematic review. Clin Infect Dis 2017;65:1757-62.

520. Austin ED, Sullivan SB, Whittier S, Lowy FD, Uhlemann AC. Peripheral intravenous catheter placement is an underrecognized source of Staphylococcus aureus bloodstream infection. Open Forum Infect Dis 2016;3:ofw072.

521. Le Moing V, Alla F, Doco-Lecompte T, Delahaye F, Piroth L, Chirouze C, et al. Staphylococcus aureus bloodstream infection and endocarditis--a prospective cohort study. PLoS One 2015;10:e0127385.

522. Trevino SE, Kollef MH. Management of infections with drug-resistant organisms in critical care: an ongoing battle. Clin Chest Med 2015;36:531-41.

523. Roberts JA, Paul SK, Akova M, Bassetti M, De Waele JJ, Dimopoulos G, et al. DALI: defining antibiotic levels in intensive care unit patients: are current $\beta$-lactam antibiotic doses sufficient for critically ill patients? Clin Infect Dis 2014;58:1072-83.

524. Neuville M, El-Helali N, Magalhaes E, Radjou A, Smonig R, Soubirou JF, et al. Systematic overdosing of oxa- and cloxacillin in severe infections treated in ICU: risk factors and side effects. Ann Intensive Care 2017;7:34.

525. Yuan SM. Infective Endocarditis during pregnancy. J Coll Physicians Surg Pak 2015;25:134-9.

526. Kebed KY, Bishu K, Al Adham RI, Baddour LM, Connolly HM, Sohail MR, et al. Pregnancy and postpartum infective endocarditis: a systematic review. Mayo Clin Proc 2014;89:1143-52.

527. Vizzardi E, De Cicco G, Zanini G, D’Aloia A, Faggiano $\mathrm{P}$, Lo Russo $\mathrm{R}$, et al. Infectious endocarditis during pregnancy, problems in the decision-making process: a case report. Cases J 2009;2:6537.

528. Connolly C, O’Donoghue K, Doran H, McCarthy FP. Infective endocarditis in pregnancy: Case report and review of the literature. Obstet Med 2015;8:102-4.

529. Barth WH Jr. Cardiac surgery in pregnancy. Clin Obstet Gynecol 2009;52:630-46.

530. Eliopoulos GM. Principles of anti-infective therapy. In: Bennett JE, Dolin R, Blaser MJ, editors. Mandell, Douglas, and Bennett's Principles and Practice of Infectious Diseases. 8th ed. Philadelphia: Elsevier Saunders; 2015. p. 224-34.

531. Mistiaen WP. Infective endocarditis in cancer patients: incidence, mechanisms and approach. Clin J Heart Dis 2017;1:1003-4.

532. Fernández-Cruz A, Muñoz P, Sandoval C, Fariñas C, Gutiérrez-Cuadra M, Pericás Pulido JM, et al. Infective endocarditis in patients with cancer: a consequence of invasive procedures or a harbinger of neoplasm?: A prospective, multicenter cohort. Medicine (Baltimore) 2017;96:e7913.

533. Thomsen RW, Farkas DK, Friis S, Sværke C, Ording AG, Nørgaard $M$, et al. Endocarditis and risk of cancer: a Danish nationwide cohort study. Am J Med 2013;126:58-67.
534. Sun LM, Wu JN, Lin CL, Day JD, Liang JA, Liou LR, et al. Infective Endocarditis and Cancer Risk: A PopulationBased Cohort Study. Medicine (Baltimore) 2016;95:e3198.

535. Melenotte C, Million M, Audoly G, Gorse A, Dutronc H, Roland G, et al. B-cell non-Hodgkin lymphoma linked to Coxiella burnetii. Blood 2016;127:113-21.

536. Kuruvilla J, Forrest DL, Lavoie JC, Nantel SH, Shepherd JD, Song KW, et al. Characteristics and outcome of patients developing endocarditis following hematopoietic stem cell transplantation. Bone Marrow Transplant 2004;34:969-73.

537. Snygg-Martin U, Rasmussen RV, Hassager C, Bruun NE, Andersson R, Olaison L. Warfarin therapy and incidence of cerebrovascular complications in left-sided native valve endocarditis. Eur J Clin Microbiol Infect Dis 2011;30:151-7.

538. Chan KL, Dumesnil JG, Cujec B, Sanfilippo AJ, Jue J, Turek MA, et al. A randomized trial of aspirin on the risk of embolic events in patients with infective endocarditis. J Am Coll Cardiol 2003;42:775-80.

539. Duval X, Leport C. Prophylaxis of infective endocarditis: current tendencies, continuing controversies. Lancet Infect Dis 2008;8:225-32.

540. Glenny AM, Oliver R, Roberts GJ, Hooper L, Worthington HV. Antibiotics for the prophylaxis of bacterial endocarditis in dentistry. Cochrane Database Syst Rev 2013;10:CD003813.

541. Cahill TJ, Harrison JL, Jewell P, Onakpoya I, Chambers JB, Dayer M, et al. Antibiotic prophylaxis for infective endocarditis: a systematic review and meta-analysis. Heart 2017;103:937-44.

542. Wilson W, Taubert KA, Gewitz M, Lockhart PB, Baddour LM, Levison M, et al. Prevention of infective endocarditis: guidelines from the American Heart Association: a guideline from the American Heart Association Rheumatic Fever, Endocarditis, and Kawasaki Disease Committee, Council on Cardiovascular Disease in the Young, and the Council on Clinical Cardiology, Council on Cardiovascular Surgery and Anesthesia, and the Quality of Care and Outcomes Research Interdisciplinary Working Group. Circulation 2007;116:1736-54.

543. Gould FK, Elliott TS, Foweraker J, Fulford M, Perry JD, Roberts GJ, et al. Guidelines for the prevention of endocarditis: report of the Working Party of the British Society for Antimicrobial Chemotherapy. J Antimicrob Chemother 2006;57:1035-42.

544. Daly CG, Currie BJ, Jeyasingham MS, Moulds RF, Smith JA, Strathmore NF, et al. A change of heart: the new infective endocarditis prophylaxis guidelines. Aust Dent J 2008;53:196-200.

545. Naber CK, Al-Nawas B, Baumgartner H, Becker HJ, Block M, Erbel R, et al. Prophylaxe der infektiösen Endokarditis. Kardiologe 2007;1:243-50.

546. Tubiana S, Blotière PO, Hoen B, Lesclous P, Millot S, Rudant J, et al. Dental procedures, antibiotic prophylaxis, and endocarditis among people with prosthetic heart valves: nationwide population based cohort and a case crossover study. BMJ 2017;358:j3776.

547. Chen TT, Yeh YC, Chien KL, Lai MS, Tu YK. Risk of infective endocarditis after invasive dental treatments. 
Circulation 2018;138:356-63.

548. Janszky I, Gémes K, Ahnve S, Asgeirsson H, Möller J. Invasive procedures associated with the development of infective endocarditis. J Am Coll Cardiol 2018;71:2744-52.

549. Lacassin F, Hoen B, Leport C, Selton-Suty C, Delahaye F, Goulet V, et al. Procedures associated with infective endocarditis in adults. A case control study. Eur Heart J 1995;16:1968-74.

550. Duval X, Alla F, Hoen B, Danielou F, Larrieu S, Delahaye $\mathrm{F}$, et al. Estimated risk of endocarditis in adults with predisposing cardiac conditions undergoing dental procedures with or without antibiotic prophylaxis. Clin Infect Dis 2006;42:e102-7.

551. Lockhart PB, Brennan MT, Sasser HC, Fox PC, Paster BJ, Bahrani-Mougeot FK. Bacteremia associated with toothbrushing and dental extraction. Circulation 2008;117:3118-25.

552. Veloso TR, Amiguet M, Rousson V, Giddey M, Vouillamoz $\mathrm{J}$, Moreillon P, et al. Induction of experimental endocarditis by continuous low-grade bacteremia mimicking spontaneous bacteremia in humans. Infect Immun 2011;79:2006-11.

553. Lee P, Shanson D. Results of a UK survey of fatal anaphylaxis after oral amoxicillin. J Antimicrob Chemother 2007;60:1172-3.

554. Nemoto H, Nomura R, Ooshima T, Nakano K. Distribution of amoxicillin-resistant oral streptococci in dental plaque specimens obtained from Japanese children and adolescents at risk for infective endocarditis. J Cardiol 2013;62:296-300.

555. Thornhill MH, Dayer MJ, Forde JM, Corey GR, Chu $\mathrm{VH}$, Couper DJ, et al. Impact of the NICE guideline recommending cessation of antibiotic prophylaxis for prevention of infective endocarditis: before and after study. BMJ 2011;342:d2392.

556. Dayer MJ, Chambers JB, Prendergast B, Sandoe JA, Thornhill MH. NICE guidance on antibiotic prophylaxis to prevent infective endocarditis: a survey of clinicians' attitudes. QJM 2013;106:237-43.

557. Dayer MJ, Jones S, Prendergast B, Baddour LM, Lockhart $\mathrm{PB}$, Thornhill $\mathrm{MH}$. Incidence of infective endocarditis in England, 2000-13: a secular trend, interrupted time-series analysis. Lancet 2015;385:1219-28.

558. Desimone DC, Tleyjeh IM, Correa de Sa DD, Anavekar NS, Lahr BD, Sohail MR, et al. Incidence of infective endocarditis caused by viridans group streptococci before and after publication of the 2007 American Heart Association's endocarditis prevention guidelines. Circulation 2012;126:60-4.

559. Pasquali SK, He X, Mohamad Z, McCrindle BW, Newburger JW, Li JS, et al. Trends in endocarditis hospitalizations at US children's hospitals: impact of the 2007 American Heart Association Antibiotic Prophylaxis Guidelines. Am Heart J 2012;163:894-9.

560. Pant S, Patel NJ, Deshmukh A, Golwala H, Patel N, Badheka A, et al. Trends in infective endocarditis incidence, microbiology, and valve replacement in the United States from 2000 to 2011. J Am Coll Cardiol 2015;65:2070-6.

561. Alam M, Bastakoti B. Therapeutic guidelines: antibiotic. Version 15. Aust Prescr 2015;38:137.
562. Özveri-Koyuncu B, Kandemir S, Sezer FB, Günbay TB. Physician compliance with American Heart Association guidelines for prevention of bacterial endocarditis in dental procedures. Turk J Med Sci 2011;41:851-8.

563. Peeters B, Herijgers P, Beuselinck K, Verhaegen J, Peetermans WE, Herregods MC, et al. Added diagnostic value and impact on antimicrobial therapy of 16S rRNA PCR and amplicon sequencing on resected heart valves in infective endocarditis: a prospective cohort study. Clin Microbiol Infect 2017;23:888.e1-e5.

564. Lockhart PB, Brennan MT, Thornhill M, Michalowicz BS, Noll J, Bahrani-Mougeot FK, et al. Poor oral hygiene as a risk factor for infective endocarditis-related bacteremia. J Am Dent Assoc 2009;140:1238-44.

565. Lockhart PB. Antibiotic prophylaxis for dental procedures: are we drilling in the wrong direction? Circulation 2012;126:11-2.

566. Periodontal Country Profiles, Oral Health Database, 2018 [İnternet]. Geneva: WHO. Available at: http://www.dent. niigata-u.ac.jp/prevent/perio/perio.html [Accessed: May 01, 2019].

567. Baltimore RS, Gewitz M, Baddour LM, Beerman LB, Jackson MA, Lockhart PB, et al. Infective endocarditis in childhood: 2015 update: A scientific statement from the American Heart Association. Circulation 2015;132:1487-515.

568. Ekkelenkamp MB, van der Bruggen $\mathrm{T}$, van de Vijver DA, Wolfs TF, Bonten MJ. Bacteremic complications of intravascular catheters colonized with Staphylococcus aureus. Clin Infect Dis 2008;46:114-8.

569. Ruhe JJ, Menon A. Clinical significance of isolated Staphylococcus aureus central venous catheter tip cultures. Clin Microbiol Infect 2006;12:933-6.

570. van Eck van der Sluijs A, Oosterheert JJ, Ekkelenkamp MB, Hoepelman IM, Peters EJ. Bacteremic complications of intravascular catheter tip colonization with Gram-negative micro-organisms in patients without preceding bacteremia. Eur J Clin Microbiol Infect Dis 2012;31:1027-33.

571. Park KH, Kim SH, Song EH, Jang EY, Lee EJ, Chong YP, et al. Development of bacteraemia or fungaemia after removal of colonized central venous catheters in patients with negative concomitant blood cultures. Clin Microbiol Infect 2010;16:742-6.

572. Wertheim HF, van Kleef M, Vos MC, Ott A, Verbrugh HA, Fokkens W. Nose picking and nasal carriage of Staphylococcus aureus. Infect Control Hosp Epidemiol 2006;27:863-7.

573. Saadatian-Elahi M, Tristan A, Laurent F, Rasigade JP, Bouchiat C, Ranc AG, et al. Basic rules of hygiene protect health care and lab workers from nasal colonization by Staphylococcus aureus: an international cross-sectional study. PLoS One 2013;8:e82851.

574. Kitten T, Munro CL, Wang A, Macrina FL. Vaccination with FimA from Streptococcus parasanguis protects rats from endocarditis caused by other viridans streptococci. Infect Immun 2002;70:422-5.

575. Spellberg BJ, Ibrahim AS, Avanesian V, Fu Y, Myers C, Phan QT, et al. Efficacy of the anti-Candida rAls3p-N or rAls1p-N vaccines against disseminated and mucosal 
candidiasis. J Infect Dis 2006;194:256-60.

576. Weems JJ Jr, Steinberg JP, Filler S, Baddley JW, Corey GR, Sampathkumar P, et al. Phase II, randomized, double-blind, multicenter study comparing the safety and pharmacokinetics of tefibazumab to placebo for treatment of Staphylococcus aureus bacteremia. Antimicrob Agents Chemother 2006;50:2751-5.

577. Rupp ME, Holley HP Jr, Lutz J, Dicpinigaitis PV, Woods CW, Levine DP, et al. Phase II, randomized, multicenter, double-blind, placebo-controlled trial of a polyclonal antiStaphylococcus aureus capsular polysaccharide immune globulin in treatment of Staphylococcus aureus bacteremia. Antimicrob Agents Chemother 2007;51:4249-54.

578. ClinicalTrials.gov Database. A study of the safety and efficacy of $514 \mathrm{G} 3$ in subjects hospitalized with bacteremia due to Staphylococcus aureus [İnternet]. Bethesda, MD: National Institutes of Health. Available at: https://clinicaltrials.gov/ct2/ show/NCT02357966 [Accessed: May 01, 2019].

579. Otero A. XBiotech announces top-line results for 514G3 antibody therapy in serious Staphylococcus aureus infections [İnternet]. Los Angeles, CA: Globe Newswire. Available at: https:/globenewswire.com/newsrelease/2017/04/03/953500/0/en/XBiotech-AnnouncesTop-Line-Results-for-514G3-Antibody-Therapyin-Serious-Staphylococcus-aureus-Infections.html [Accessed: May 01, 2019].

580. Benjamin DK, Schelonka R, White R, Holley HP, Bifano
E, Cummings J, et al. A blinded, randomized, multicenter study of an intravenous Staphylococcus aureus immune globulin. J Perinatol 2006;26:290-5.

581. DeJonge M, Burchfield D, Bloom B, Duenas M, Walker W, Polak M, et al. Clinical trial of safety and efficacy of INH-A21 for the prevention of nosocomial staphylococcal bloodstream infection in premature infants. J Pediatr 2007;151:260-5.

582. Weisman LE, Thackray HM, Steinhorn RH, Walsh WF, Lassiter HA, Dhanireddy R, et al. A randomized study of a monoclonal antibody (pagibaximab) to prevent staphylococcal sepsis. Pediatrics 2011;128:271-9.

583. Shinefield H, Black S, Fattom A, Horwith G, Rasgon S, Ordonez J, et al. Use of a Staphylococcus aureus conjugate vaccine in patients receiving hemodialysis. N Engl J Med 2002;346:491-6.

584. Fowler VG, Allen KB, Moreira ED, Moustafa M, Isgro $\mathrm{F}$, Boucher $\mathrm{HW}$, et al. Effect of an investigational vaccine for preventing Staphylococcus aureus infections after cardiothoracic surgery: a randomized trial. JAMA 2013;309:1368-78.

585. ClinicalTrials.gov. Database. Safety and efficacy of SA4Ag vaccine in adults having elective open posterior spinal fusion procedures with multilevel instrumentation (STRIVE) [İnternet]. Bethesda, MD: National Institutes of Health. Available at: https:/clinicaltrials.gov/ct2/show/ NCT02388165 [Accessed: May 01, 2019]. 